\title{
Learning Lessons to Promote Forest Certification and Control Illegal Logging in Indonesia
}

Luca Tacconi

Krystof Obidzinski

Ferdinandus Agung

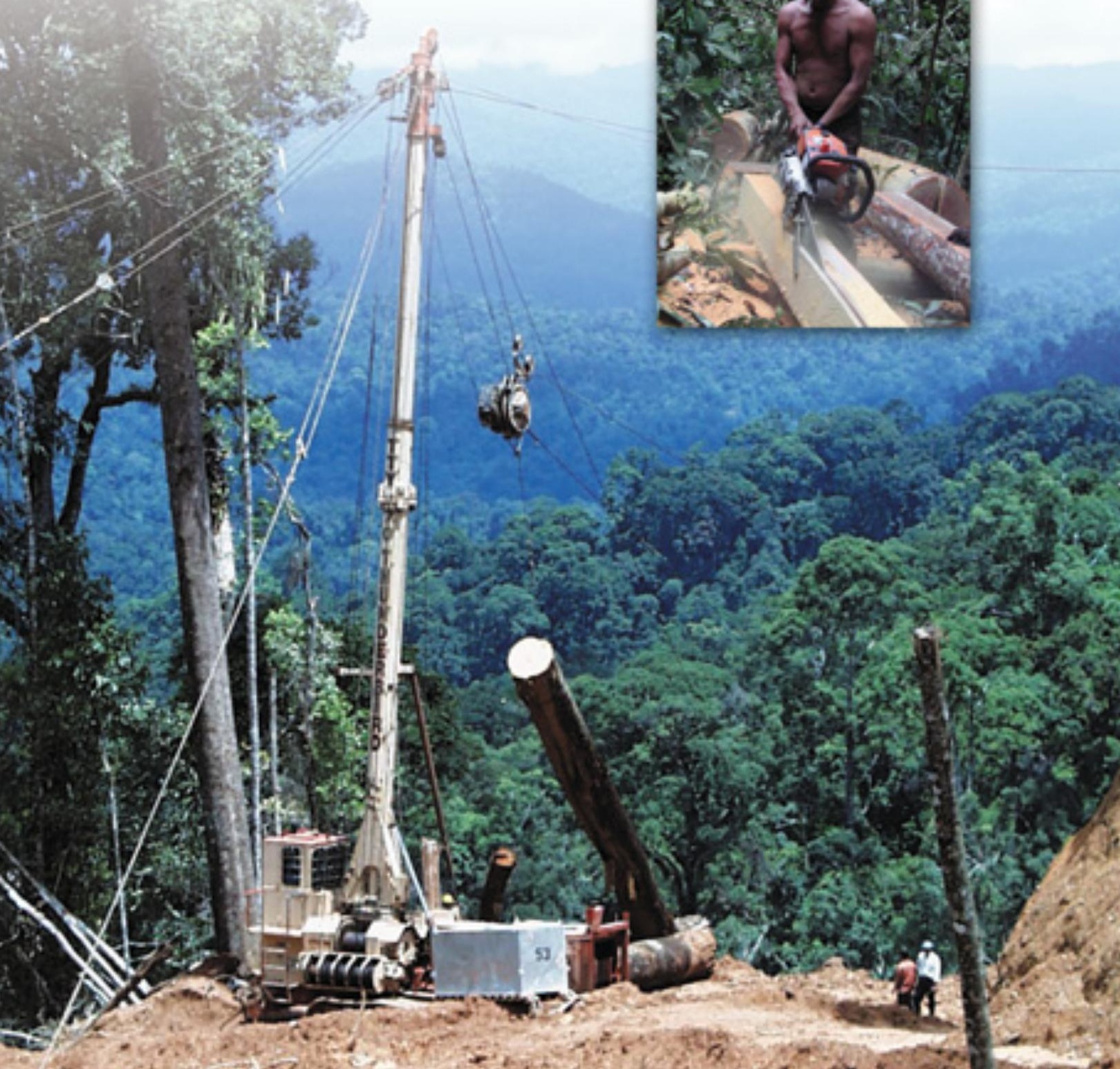




\section{Learning Lessons to Promote Forest Certification and Control Illegal Logging in Indonesia}

Year One: 1 October 2002 to 31 September 2003

Luca Tacconi, Krystof Obidzinski and Ferdinandus Agung

Center for International Forestry Research (CIFOR)

For the Alliance to Promote Forest Certification and Combat Illegal Logging in Indonesia

The Nature Conservancy (TNC); and World Wide Fund for Nature (WWF)

Sponsored by United States Agency for International Development (USAID) 
(c) 2004 by CIFOR

All rights reserved. Published in 2004

Cover photos by Ferdinandus Agung

Published by

Center for International Forestry Research

Mailing address: P.O. Box 6596 J KPWB, J akarta 10065, Indonesia

Office address: JI. CIFOR, Situ Gede, Sindang Barang,

Bogor Barat 16680, Indonesia

Tel.: +62 (251) 622622; Fax: +62 (251) 622100

E-mail: cifor@cgiar.org

Web site: http:// www. cifor. cgiar. org 


\section{Contents}

\section{Acronyms}

Introduction

\section{Part 1. The Illegal Logging Problem}

Indonesian Forests and Illegality 3

The various forms of illegality 3

Illegal timber production in Indonesia and trade $\quad 4$

The market for certified and legally verified timber 6

Threats to the forest and causes of illegal logging 8

National and International Policies and Illegal Logging 12

Transition from the Suharto period $\quad 12$

Recent policy changes: log export ban, 'soft landing',

International policies on illegal logging and illegal timber trade 15

\section{Part 2. Taking Action}

The Alliance's Rationale and Strategy

Strengthening Market Signals to Produce Certified and Verified Legal

Timber, and Increasing Its Supply from Indonesia 21

Increasing market signals and the stepwise approach to certification 21

The Global Forest and Trade Network $\quad 22$

Promoting certification in China and Japan 22

Certification in Indonesia and Malaysia 23

Promoting responsible Sourcing of timber in Riau 25

Certification and GFTN-community-based forest management in Central J ava and Yogyakarta $\quad 27$

Certification and GFTN in East Kalimantan $\quad 29$

Do the assumptions hold? 32 
Financial Measures to Promote Responsible Forestry and to Reduce Illegal Logging

Can financial tools help? $\quad 35$

Indonesian forestry and finance $\quad 36$

Export credit agencies and money laundering 37

Do the assumptions hold? 38

Maintaining High Conservation Value Forests $\quad 39$

What are HCVFs? $\quad 39$

HCVFs in Indonesia $\quad 40$

Do the assumptions hold? 43

Building Capacity to Reduce Illegal Logging 44

Timber tracking and verification in perspective 44

Do the assumptions hold? 46

Learning with Partners $\quad 46$

Rural people, civil society, and the private sector 47

Government institutions 48

Do the assumptions hold? $\quad 49$

Part 3. Summary of Findings and Recommendations

Learning Lessons and Adapting $\quad 50$

Achievements of the year: was the Alliance successful? 50

Obstacles to the progress of Alliance 52

How well is the program moving towards its goal? 52

Learning and adapting 53

$\begin{array}{ll}\text { Endnotes } & 57\end{array}$

$\begin{array}{lr}\text { References } & 59\end{array}$

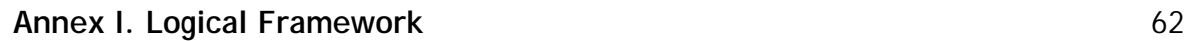

Annex II. CIFOR's Terms of Reference for Preparation of
the Annual Report

Annex III. People and Organisations Contacted 80 


\section{Acronyms}

\begin{tabular}{|c|c|}
\hline AAC & annual allowable cut \\
\hline APHI & Association of Indonesian Forest Concessionaires \\
\hline APHI & Indonesian Association of Timber Concessionaires \\
\hline APKINDO & Indonesian Association of Plywood Producers \\
\hline APP & Asia Pulp and Paper \\
\hline APRIL & Asia Pacific Resources International Holdings Limited \\
\hline ARUPA & $\begin{array}{l}\text { Aliansi Relawan untuk Penyelamat Alam (Volunteers Alliance for } \\
\text { Saving the Nature) }\end{array}$ \\
\hline BPS & Badan Pusat Statistik (Statistics Indonesia) \\
\hline CBFM & community-based forest management \\
\hline CFP & certified forest product \\
\hline CIFOR & Center for International Forestry Research \\
\hline CITES & $\begin{array}{l}\text { Convention on the International Trade in Endangered Species } \\
\text { of Flora and Fauna }\end{array}$ \\
\hline $\mathrm{CoC}$ & chain of custody \\
\hline ECA & export credit agency \\
\hline EU & European Union \\
\hline FERN & Forests and European Union Resources Network \\
\hline FLEG & Forest Law Enforcement Government \\
\hline FSC & Forest Stewardship Council \\
\hline FTN & forest and trade networks \\
\hline FWI & Forest Watch Indonesia \\
\hline GFTN & global forest and trade network \\
\hline GIS & Geographic Information System \\
\hline GTZ & Gesellschaft für Technische Zusammenarbeit \\
\hline HCVF & high conservation value forest \\
\hline $\mathrm{HPH}$ & forest concession \\
\hline HTI & timber plantation \\
\hline IPK & forest being converted to other uses \\
\hline ITTO & International Tropical Timber Organization \\
\hline LEI & Lembaga Ekolabel Indonesia (Indonesian Ecolabeling Institute) \\
\hline MC\&I & Malaysia Criteria \& Indicators \\
\hline NGO & nongovernmental organization \\
\hline PERSEPSI & $\begin{array}{l}\text { Perhimpunan untuk Studi dan Pengembangan ekonomi dan } \\
\text { Sosial (Association for Study and Social Economic } \\
\text { Development) }\end{array}$ \\
\hline RAPP & Riau Andalan Pulp and Paper \\
\hline SFM & sustainable forest management \\
\hline SGS & Societe Generale de Surveillance \\
\hline TFT & Tropical Forest Trust \\
\hline TNC & The Nature Conservancy \\
\hline USA & United States of America \\
\hline USAID & United States Agency for International Development \\
\hline WWF & World Wide Fund for Nature \\
\hline
\end{tabular}




\section{Introduction}

Concern about illegal logging is widespread. Illegal logging has negative environmental impacts, results in the loss of forest products used by rural communities, creates conflicts, and causes significant losses of tax revenues that could otherwise be used for development activities. In Indonesia, the tax loss from illegal logging in 1998 was estimated at about US $\$ 1.5$ billion (Palmer 2001), well above the annual public health expenditure of US\$900 million and equal to the annual foreign aid budget. ${ }^{1}$

The Nature Conservancy (TNC) and World Wide Fund for Nature (WWF) developed the Alliance to Promote Certification and Combat Illegal Logging (hereafter referred to as the Alliance) to respond to the concern about illegal logging. The Alliance is a three-year initiative that aims to:

1. Strengthen market signals to expand certification and combat illegal logging

2. Increase supply of certified Indonesian wood products

3. Demonstrate practical solutions to achieve certification and differentiate legal and illegal supplies

4. Reduce financing and investment in companies engaged in destructive or illegal logging in Indonesia

5. Share lessons learned from the project.

The Alliance seeks to learn lessons from its ongoing work to inform and adapt its activities, as well as to inform other initiatives seeking to address similar problems. This report is part of this lessons learning process.

The lessons learning framework developed by the Alliance takes the following form: ${ }^{2}$

- Statement of problem

- Suggested solutions

- Clear statement of actions being taken for what purpose

- Assessment as to whether specified actions end in solutions being achieved.

The solutions suggested by the Alliance to address the problem of illegal logging and the actions being taken are stated in the logical framework (Annex I). This report contributes to the assessment of whether specified actions end in solutions being achieved.

This first report focuses particularly on compiling background and baseline information, highlights apparent major causes of illegal logging (relying mainly on previous work by the Center for International Forestry Research [CIFOR]), presents the most significant assumptions underlying the work of the Alliance, and proposes 
some recommendations for the work to be carried out by the Alliance. As the Alliance's work progresses, more information will become available to understand its impacts and the implications of the assumptions underlying the activities. Therefore, the next report will focus to a greater extent on the lessons that can be learnt from the ongoing impacts and whether the assumptions hold.

The report is organized according to the CIFOR Terms of Reference (extract presented in Annex II). The initial outline of the report was agreed upon in discussions among CIFOR, TNC, and WWF. It is based on field visits to Central Java, East Kalimantan, and Riau, discussions with Alliance staff, interviews with a range of stakeholders, and a review of relevant published and unpublished literature.

Part 1 of the report assesses the current situation in Indonesia, including a quantitative estimation of illegally produced logs, discusses the causes of illegal logging, and describes the national and international policy and trade context. This part provides the national and international background information needed to put into context the impact the Alliance has and to understand the factors that may influence its success.

Part 2 considers the work undertaken by the Alliance to address illegal logging in Indonesia. It summarizes the strategy of the Alliance, describes its rationale, and assesses the assumptions underlying the rationale and the objectives.

Part 3 summarizes the progress made by the Alliance towards achieving its goal, highlights the lessons that can be learnt from the work in progress, and provides recommendations for the Alliance. The reader interested only in the summary of progress and future issues is directed to this section.
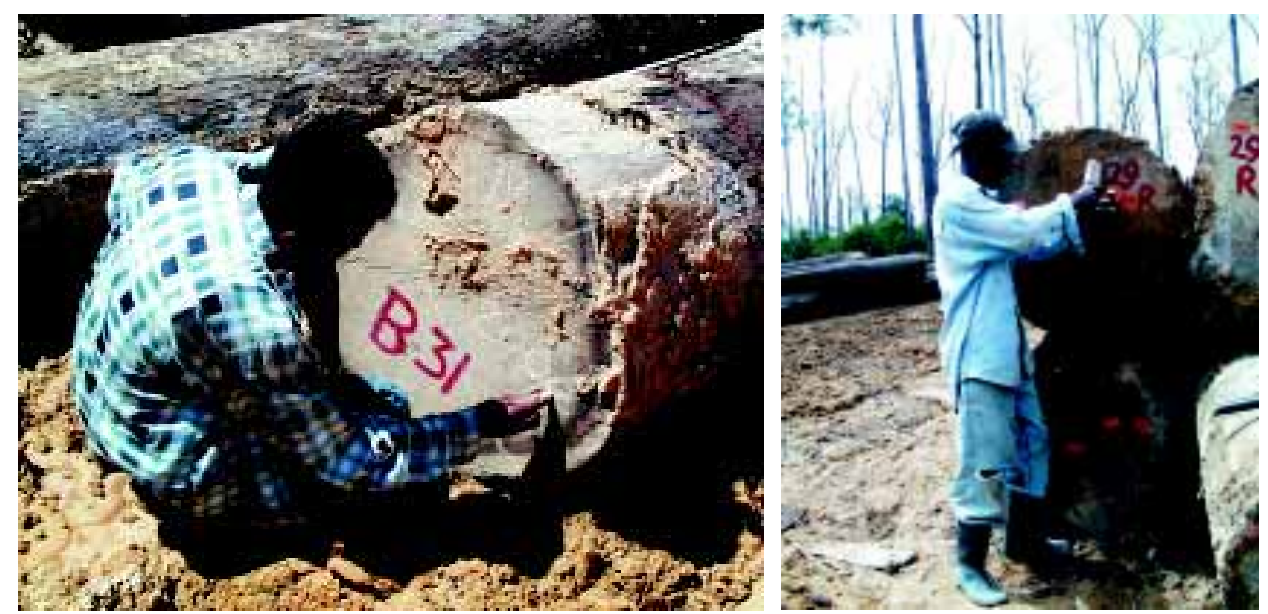

Documenting source of origin of logs in forest concession. (Photo by Ferdinandus Agung) 


\section{Part 1. The Illegal Logging Problem}

\section{Indonesian Forests and IIlegality}

\section{The various forms of illegality}

The term 'illegal logging' is often used to refer to a range of illegal activities affecting the forest and the people who depend on it. It is therefore useful to consider the meaning of this concept.

There are several definitions of illegal forest activities and illegal logging. A clear, practical, and accepted definition of legality is required for each country as basis of market instruments, such as verification of legality, and for law enforcement. There are many challenges in developing such a definition of legality, such as drawing a line between a significant offence and a minor transgression and conflicts between customary and formal laws (Dykstra et al. 2002). Here, we provide a summary of what may constitute illegal forest activities. We do not intend to provide a specific definition. The Alliance, as discussed later in this report, is working on a definition of legality for Indonesia.

Illegal forest activities include all illegal acts that relate to forest ecosystems, forest-related industries, and timber and non-timber forest products. They include acts violating rights to forest land, corrupt activities to acquire forest concessions, and activities at all the stages of forest management and the forest goods production chain, from the planning stages to harvesting and transport of raw material and finished products to financial management (Tacconi et al. 2003).

Violations of indigenous peoples' rights, public trust, and public or private ownership rights may involve acts against constitutional, civil, criminal, or administrative law. Violations of forest management regulations in either public or private forestlands are acts against forest legislation. This is the category that includes most of the acts that may be most appropriately referred to as 'illegal logging'.

Violations of transport and trade regulations include acts that infringe forest legislation, but they may be related to legally or illegally harvested forest products. This category is referred to as 'illegal trade in forest products'. Timber processing activities may be regulated by industry-and trade-related legislation as well as forest legislation. In this category, the use of illegally harvested logs is a violation directly linked to illegal logging.

Violation of financial, accounting, and tax regulations may involve acts related to legally or illegally harvested and traded timber. This category may be referred to as 'illegal financial activities'. 
For initiatives aimed at addressing illegal forest activities, or, more specifically, illegal logging, it may be inappropriate, however, to take the existing law as a given in situations in which the law itself does not have broad social and institutional acceptance. This is the case in Indonesia. Therefore, to understand fully the problem and possible solutions, the analysis needs to consider existing forestry and other laws, the type of activities infringing the law, and the social and economic causes of these activities (e.g., Dykstra et al. 2002; Colchester et al. forthcoming).

\section{Illegal timber production in Indonesia and trade}

The proportion of illegal harvest, a benchmark to be considered by the Alliance, is significant. It was estimated at about $64 \%$ of total harvest in 2000 and $83 \%$ in 2001 (Table 1). As data on the Indonesian forestry sector are notoriously unreliable, the figures in Table 1 are only indicative and must be interpreted with caution. Nevertheless, it appears that the substantial increase in the apparent level of illegal harvest between 2000 and 2001 is only partly a result of an increase in the use of round-wood equivalent (about 14\%). A more significant factor leading to the increase in illegal harvesting is the reduction in the recorded official harvest in line with the policy-discussed later in the report-to reduce the annual allowable cut. ${ }^{3}$

In 2000, log inputs for plywood production represented the largest contribution to total harvest, followed by pulp and paper and sawn wood. In 2001, pulp and paper requirements were the largest contributor, followed by plywood and sawn wood.

International demand for wood products accounted for about $59 \%$ of roundwood equivalent in 2000, and for $68 \%$ in 2001 . Exports accounted for $63 \%$ and $67 \%$ respectively, of round-wood equivalent for plywood production in 2000 and 2001 , for $68 \%$ and $61 \%$ of pulp and paper, and for $22 \%$ and $39 \%$ of sawn wood. In $2000,37 \%$ of the round-wood equivalent content of pulp was exported directly and a further $31 \%$ was exported in the form of paper; in 2001, the respective export shares were $33 \%$ and $28 \%$

The largest share of round-wood equivalent is exported in the form of processed wood products rather than as logs. This distinction is significant because recently the Indonesian government has put a strong spotlight on the failure of its neighbours to stop the import of illegal logs from Indonesia. While the volume of illegally exported logs is not negligible, being in the order of several million cubic metres, it is at most some $10 \%$ of total log harvest.

Domestic demand absorbs a considerable share of round-wood equivalent. Domestic sawn wood consumption amounted to $78 \%$ of total production in 2000 and $61 \%$ in 2001; the respective percentages for paper were $51 \%$ and $59 \%$ Plywood had lower shares of domestic consumption, at $27 \%$ and $23 \%$ respectively. Domestic demand for round-wood equivalent was about 21.6 million cubic metres in 2000 and 19.2 million cubic metres in 2001. These figures imply that domestic demand was just above legal harvest in 2000 and well above it in 2001-and it is likely that domestic demand is underestimated. This finding has significant implications for policy.

First, consider the case that all countries importing wood products from Indonesia required proof of legality. There are two possible scenarios. In the first one, some portion of the timber products exported could be certified to show they 


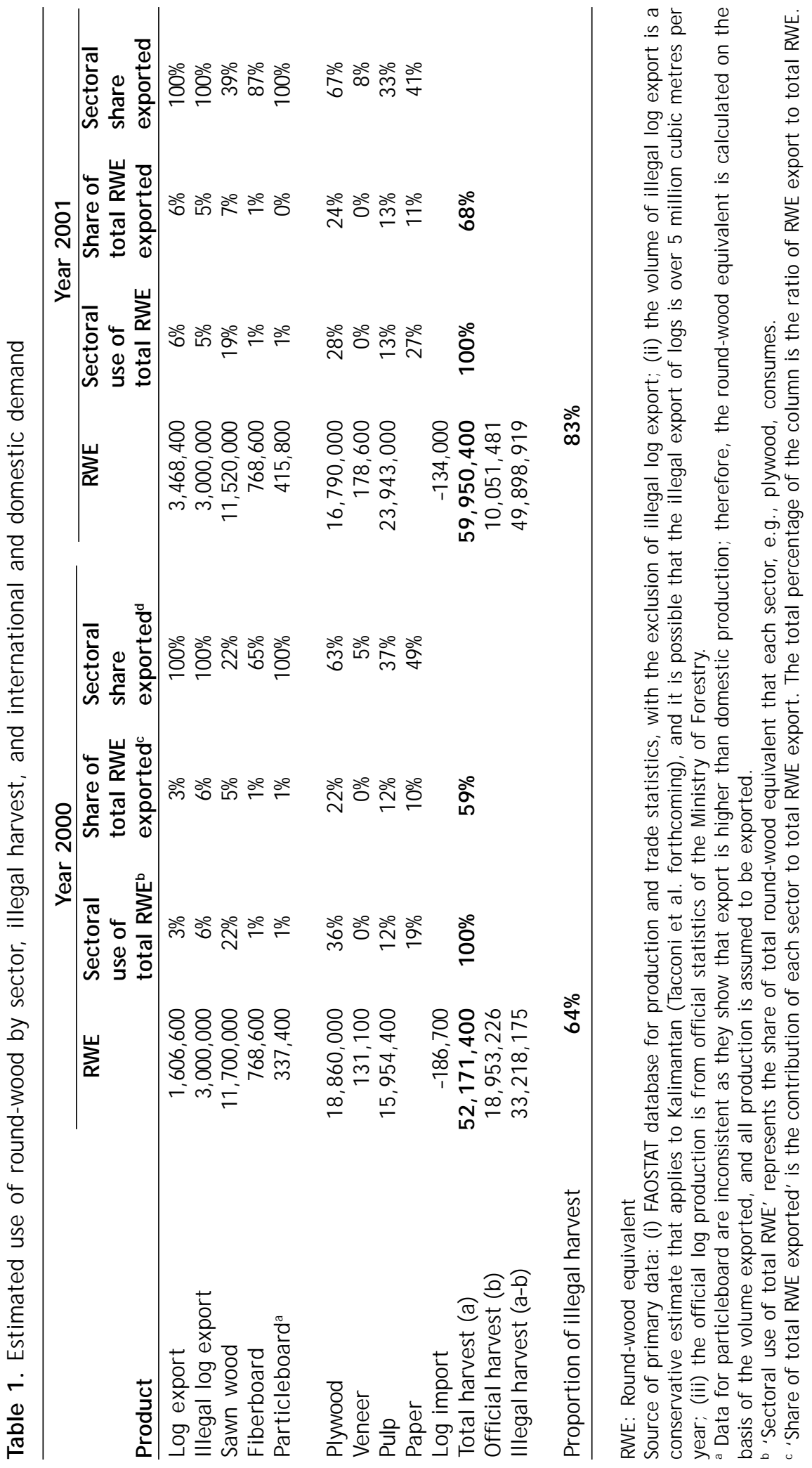


are from legal sources, and total export levels would be reduced accordingly. In the second scenario, verification of legality cannot be achieved for any timber, and production is cut by an amount equivalent to total exports. In either case, a significant portion of total wood consumption, domestic demand, would still demand roundwood equivalent at levels well above the allowable harvest planned by the Ministry of Forestry of 6.89 million cubic metres for 2003 and 5.74 million cubic metres for 2004.

Second, and related to the above, calling for a reduction in wood processing capacity in Indonesia to bring production levels in line with the sustainable harvest levels from natural forests is, at best, a rather partial solution. It actually may simply shift the illegal logging problem to other countries, given that Indonesia would have to import wood products to satisfy domestic demand. This implies that to solve the problem of illegal logging in Indonesia, while avoiding the risk of exporting it to other countries, policies aimed at increasing the legal (and preferably sustainable) supply of logs need to be put in place.

In relation to the source of legal logs, there is a trend towards a progressive reduction of the number of large forest concessions following continuing degradation of forest resources, which results in lower profitability. In 2001, the total recorded log production of $10,014,888 \mathrm{~m}^{3}$ was sourced $18.0 \%$ from forest concessions (HPH), $23.0 \%$ from forest being converted to other uses (IPK), 14.5\% from state plantations, and $44.5 \%$ from other plantations ( $\mathrm{HTI})$. In 2002, the total log production of 8, 136, $303 \mathrm{~m}^{3}$ was sourced $37.1 \%$ from HPHs, $2.2 \%$ from IPKs, $19.2 \%$ from state plantations, and $41.5 \%$ from HTIs (Ministry of Forestry data).

In 2001, there were 361 active HPHs (including 55 in the process of renewing the license), covering 36,42 million hectare. The provinces with the largest area under HPH were Papua with 10,751,613 ha (50 HPHs), East Kalimantan with 8, 168, 217 ha (74 HPHs), Central Kalimantan with 5,203,942 ha (63 HPHs), and Maluku with $2,257,942$ ha ( $28 \mathrm{HPHs}$ ). In 2002, the number of HPHs had declined to 270 covering an area of $28,077,864$ ha. The provinces with the largest area under HPHs were Papua with 10,577,073 ha (49 HPHs), East Kalimantan with 4, 443, 106 ha (41 HPHs), Maluku with 1,699, 661 ha (23 HPHs), and Central Kalimantan with 1,506, 031 ha (13 HPHs).

Regarding international trade, China has become one of the major markets for Indonesian timber products (Figure 1). In 2001, it imported $54.5 \%$ of the volume of sawn wood exported by Indonesia, $42.6 \%$ of pulp, $33.3 \%$ of particleboard, and $25.6 \%$ of paper. J apan imported $42.0 \%$ of plywood; South Korea $48.5 \%$ of fiberboard, $26.9 \%$ of particleboard, and $19.3 \%$ of pulp; the European Union almost $20 \%$ of pulp; the United States of America (USA) 9.4\% of plywood; and Saudi Arabia 55.2\% of veneer and $24.4 \%$ of fiberboard. A large share (about $37 \%$ ) of paper exports is distributed among many countries, which individually account for relatively small shares of total exports. The largest of these 'other' countries is Australia with 5\%

\section{The market for certified and legally verified timber}

The main market for certified forest products (CFPs) (paper excluded) is Europe (Table 2), where the market share of CFPs is about $5 \%$ of the total volume of wood trade (Rametsteiner 2002). The strongest demand for CFPs is in the United Kingdom and the Netherlands. The market for CFPs in China and J apan is still in its inception, and the volume of CFPs traded in both countries is negligible. 
Figure 1. Destination of timber product exports from Indonesia in 2001

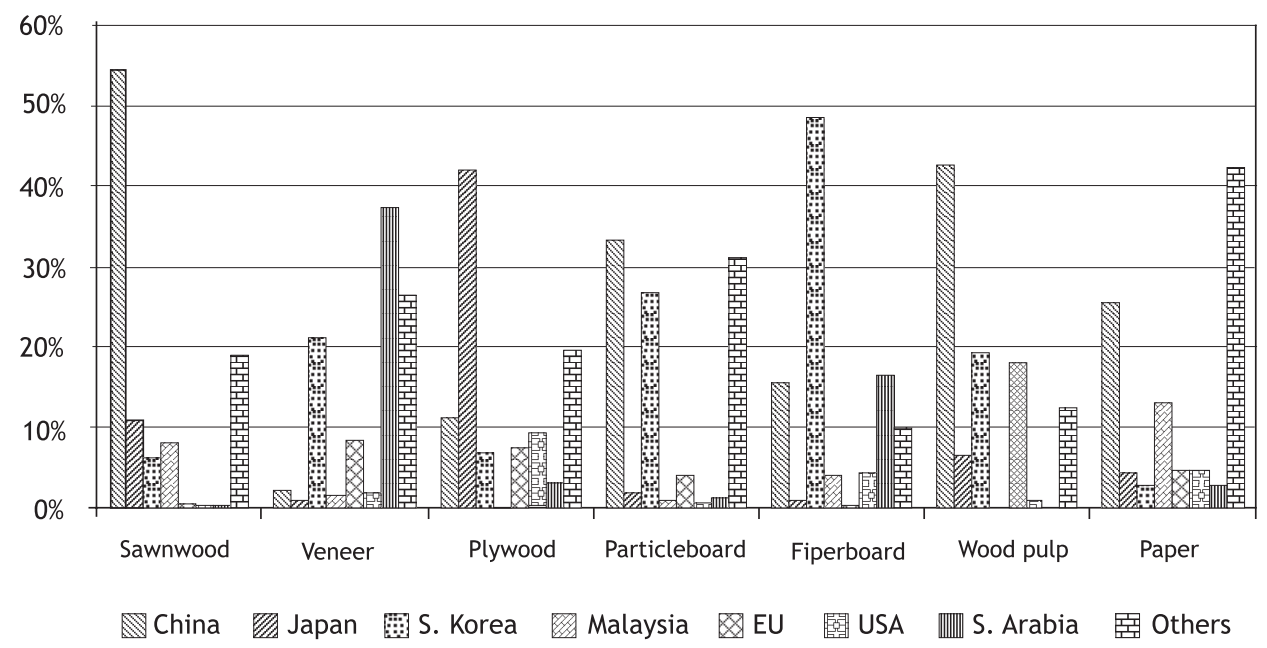

Source: Forestry Data. 2004. FAO Statistic. http://apps.fao.org/default.jsp

Table 2. Market share of certified forest products (CFPs) in key importing countries

\begin{tabular}{ll}
\hline Countries & Market share of CFPs \\
\hline United Kingdom & $10 \%$ wood \\
& $1 \%$ paper \\
Switzerland & $5 \%-10 \%$ \\
Netherlands & $7 \%$ \\
Belgium & $5 \%$ \\
Canada & $5 \%$ \\
Denmark & $5 \%$ \\
United States & $2 \%$ \\
Germany & $1 \%$ \\
Japan & $0.02 \%$ \\
\hline
\end{tabular}

Source: Rametsteiner 2002.

End consumers are not an active force driving an eco-sensitive market. Trading companies' marketing objectives drive the demand for CFPs (Rametsteiner 2002). The major factors that may determine the supply of certified products are (CCIF 2002, pp. 7-12):

1. Revenue enhancement: certification can identify for the buyer a product feature that justifies:

i) a significant price premium, or at least

ii) a strong brand preference 
2. Risk reduction: certification can serve to reduce four types of risk for the producers:

i) market risk, e.g., foreign market or major buyers may demand certification

ii) regulatory risk: voluntary certification may avoid regulatory intervention

iii) image risk, e.g., dominant companies may fear environmental campaigns

iv) natural resource risk, e.g., a species may become extinct if the market is not controlled

3. Cost reductions: certification schemes claim increases in efficiency for the certified industry:

i) improved economies of scale, e.g., greater economies of scale in production, marketing, or distribution

ii) cost-effective access to new technology and/ or processes, e.g., introduction of entirely new processes, such as quality control and waste minimization, which lead to greater efficiency

iii) lowered operational complexity, e.g., general efficiency of operations can be improved after the close scrutiny and analysis performed as part of the certification effort

CCIF (2002) notes that there is a need to assess the significance of the factors noted above. These factors are often cited in support of certification schemes, but detailed evidence substantiating their importance is lacking.

The potential annual supply from certified forests is about 234 million cubic metres. Most of this production is traded without certified status, however, because of the lack of chain of custody certificates, especially in areas that are certified through schemes known as Programme for the Endorsement of Forest Certification Schemes (formerly the Pan European Forest Certification), Sustainable Forest Initiative, and the Canadian Standard Association (Rametsteiner 2002).

Criteria to define 'legally verified timber products' are still being developed. Definitions are expected to focus on compliance with existing national legislation. They will not include reference to the sustainability of forest management.

The market for legally verified timber is practically untested. It could develop rather rapidly if the European Union introduces a regulation facilitating access to legally certified products and producing countries decided to enter into voluntary bilateral agreements with the European Union.

\section{Threats to the forest and causes of illegal logging}

In Indonesia in 1950, forests covered some 162.3 million hectares, or $84 \%$ of the land. Estimates by the $\mathrm{J}$ oint Research Centre of the European Commission put forest cover at around 105 million hectares in 2000. The deforestation rate was estimated at about 2 million hectare per year in the late 1990s (FWI/ GFW 2002; Holmes 2002).

The forest area affected by illegal logging is unknown, but a rough approximation is possible. In 2001, given an illegal harvest of about 50 million cubic metres and assuming a harvest rate of 20 cubic metres per hectare, ${ }^{4}$ illegal logging affected at least 2.5 million hectare of forest.

The relative contributions of various direct causes of deforestation are under debate because of the uncertain nature of the available data. Existing information does, however, provide an indication of the significance of the various causes. Holmes (2002) finds that the following direct causes contributed to forest loss in 
Sumatra, Kalimantan, and Sulawesi over the period 1985-1997, which totalled 17.4 million hectare (out of the total forest loss of 20 million hectare):

- Timber plantations, 1.9 million hectare (11\%)

- Estate crops, 2.4 million hectare (14\%)

- Forest fires, 1.74 million hectare (10\%)

- Small investors, 2.4 million hectare (10\%)

- Pioneer farmers, 1.22 million hectare (7\%)

As noted by Holmes, these figures account for only 9.7 million hectare. Therefore, he concludes, between one-quarter and one-half of the cleared land lay idle. According to him, this may be the result of large areas cleared with the stated intent of establishing timber plantations that, however, resulted in the planting of only $25 \%$ of the area. The timber industry has caused further forest loss, but its contribution is a matter of speculation. The pulp industry may have contributed some 900,000 ha to the loss of natural forest cover over the period 1988-2000 (Barr 2001). The 1997/ 98 fires affected some 6 million hectares of forest but the degree to which this resulted in deforestation is unknown (Tacconi 2003).

Knowledge about the underlying causes of illegal logging, necessary to develop coherent and effective measuresfor its reduction, is still relatively limited.

Illegal activities are by definition associated with infringement of the law. The illegal logging problem may, therefore, be constructed solely as a problem of difficult law enforcement (e.g., forest areas are remote and difficult to access) or weak law enforcement, possibly caused by lack of enforcement capacity or corruption.

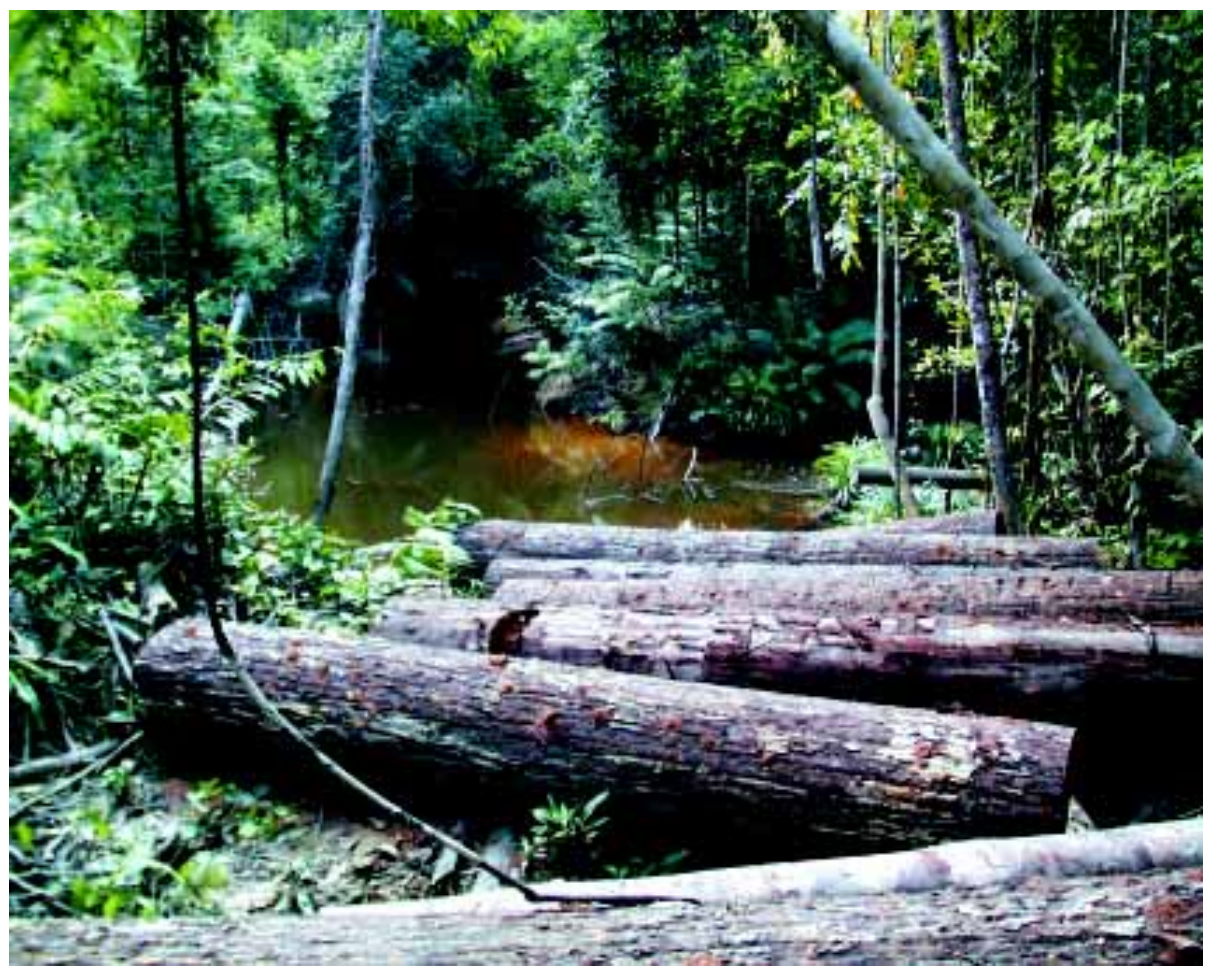

Illegal logs ready to be transported through the river. (Photo by Ferdinandus Agung) 
The issue of illegal logging in Indonesia, however, is a problem significantly more complex than just law enforcement, as demonstrated by the sheer amount of timber harvested illegally. Illegal logging is the manifestation of a problematic structural situation of the forest sector, including the policy and regulatory frameworks, economic and financial policies, the operations of the timber industry, and certainly corruption.

\section{Governance causes}

Illegal logging has been an institutionalized practice in Indonesia for decades. The Suharto regime was interested in the economic benefits generated by forest exploitation, but it also used the allocation of forest concessions to gain political support and to fund off-the-books projects (Ascher 1999). The degree to which the political establishment and the public administration (including national and local governments, the Armed Forces, and the political parties) in the post-Suharto era still rely on revenues from illegal forest activities is uncertain, but there is evidence indicating that these forces are still one of the causes of illegal logging in Indonesia (Casson and Obidzinski 2002; McCarthy 2002; Obidzinski 2003; Smith et al. 2003; Tacconi et al. forthcoming).

Processes to incorporate societal preferences about forest managementincluding concerns about the potential environmental harm of illegal logging-are not well developed. If citizens and administrators regard logging, even illegal logging, as beneficial to the community, they may not seek the enforcement of legislation. At an institutional level, there is evidence that local government officials in many cases are supportive of logging activities to increase local revenues and even 'legalize' illegal timber in order to capture revenues (Casson 2001). The introduction of a process to allocate forests to alternative land uses that is more participatory and accountable than the existing one would improve land use allocation, contribute to better forest management in areas designated as forests, and possibly reduce social conflict.

Uncertainty surrounds the policy and legal framework for forest management in Indonesia. This problem is mainly the result of the range of social and economic interests brought to the fore by the fall of the Suharto regime and the ongoing transition process. A lack of clarity and conflicting provisions in the legislation also contribute to the problem. Government Regulation 34/2002, which provides the details for the implementation of Forestry Law 41/1999, has in effect brought about, at least on paper, a recentralisation of decision making over forests by clearly stating that the central government has sole authority over them and that permits issued at the regional level are no longer valid. This status is being contested by local administrations, however. In relation to the legislation itself, it is possible to define areas of 'absolute legality' and 'absolute illegality', as well as 'grey areas' in between (Patlis 2003a). The existence in positive law of the definition of legality and illegality needs to be the starting point for the definition of what may be considered as legal timber and legal forestry operations. Lack of full social acceptance of positive law should not be confused with a lack of positive law.

Corruption is widespread. In 2003, Transparency International ranked Indonesia as the 11th most corrupt country in the world, jointly with Kenya. ${ }^{5}$ Out of 35 Indonesian public institutions, the ones most relevant to this study were ranked 
as follows, from least to most corrupt (Partnership for Governance Reform in Indonesia 2001): Armed Forces 6th, provincial governments 18th, municipal governments 19th, political parties 23rd, Ministry of Forestry 25th, police 30th, judiciary 33rd, and Customs Authority 34th. Corruption does appear to be an underlying cause of illegal logging in Indonesia (Smith et al. 2003), but whether it is the leading cause, and how it may be related to other causes, is unclear.

\section{Economic and market causes}

The financial benefits derived from illegal logging are superior to those from legal logging. This statement is a simple truth that cannot be escaped, and one that without some degree of law enforcement is always valid. In Indonesia, the estimated cost to a large forest concessionaire to deliver legal wood (including 'informal' taxes of $20 \%$ ) to the mill door is US\$85/ $\mathrm{m}^{3}$, whereas the cost of illegal timber is US $\$ 32 / \mathrm{m}^{3}$. A small concessionaire holder faces a cost of US $\$ 46 / \mathrm{m}^{3}$ to deliver wood to the mill. It costs a small-scale illegal harvesting operation just US $\$ 5 / \mathrm{m}^{3}$ to deliver wood to the roadside (URS Forestry 2002).

A market for timber that does not discern between legal and illegal products allows, even forces, timber producers and traders to produce and market the cheapest products, those derived from illegal timber. The factors that influence the supply of legally verified and/ or certified timber are revenue enhancement, cost minimization and risk reduction, as noted above. The price of illegal timber is lower than legal timber, if there is limited or absent law enforcement. In the absence of immediate and significant benefits, buyers do not seem to tolerate a price premium of more than $5 \%$ for certified products, a margin not sufficient to pay for certification costs (CCIF 2002). In some cases, buyers may be unable to pay price premiums at all, as is often the case for 'industrial customers in high-volume, low-margin manufacturing industries such as building, paper..' (CCIF 2002). Therefore, for the supply of legal products to increase, suppliers need to derive significant benefits in terms of risk reduction and/ or cost reduction, given the significant difference in price between legal and illegal timber.

In some instances, forest land yields private and social benefits, including the value of environmental benefits, lower than alternative land uses. This circumstance can lead government officials, individuals, communities, or companies to log and change the land use against the existing legislation (Tacconi et al. 2003). In other situations, the social benefits of forest conservation or sustainable forest management are higher than the benefits of conversion or unsustainable harvesting. If private benefits from illegal and unsustainable use are higher than those from legal and sustainable use, however, and compensation and compliance mechanisms are unsuitable, illegal logging results.

Existing policies and the large supply of cheap and largely illegal logs limit the financial attractiveness of timber plantations. This fact can result in a vicious circle in which, given the lack of legal timber, illegal logging continues and possibly increases over time to satisfy the demand for timber products. Only when illegally harvested timber becomes sufficiently scarce, or 'stigmatised', in the market and the log prices surpass the cost of production of plantation timber, plantation establishment would be attractive from a financial point of view. Policies that depress the domestic price of logs should be removed. This measure is a necessary 


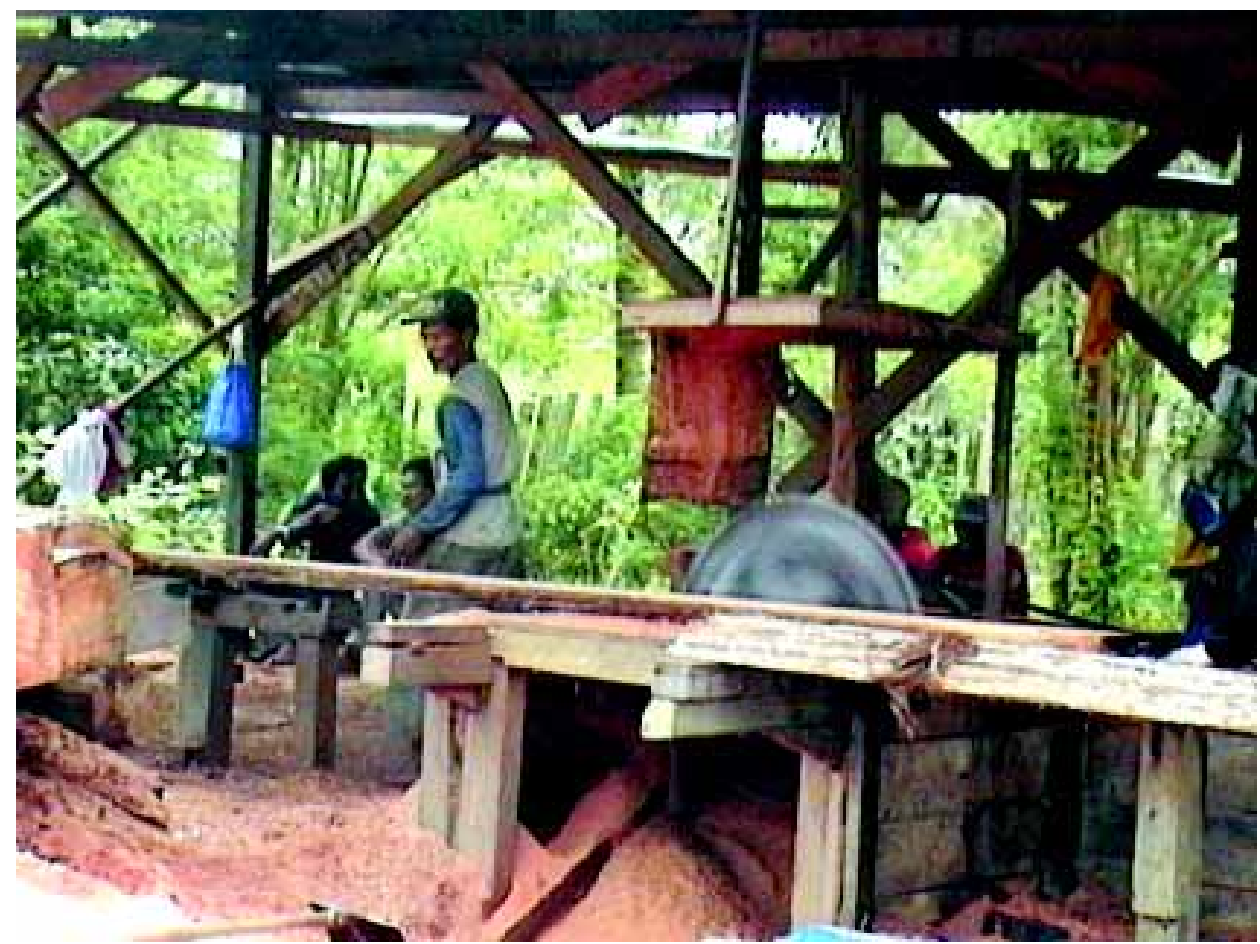

Portable sawmill, processing illegal logs into sawnwood for local market. (Photo by Agus Andrianto)

but insufficient one. Law enforcement or near blanket market rejection of wood not verified as legal would have to take place to reduce the supply of cheap illegal logs.

\section{National and International Policies and Illegal Logging}

\section{Transition from the Suharto period}

Shortly after the introduction of decentralisation legislation in 1999, legislation was also introduced that devolved elements of authority to manage forests from J akarta to the provincial and district authorities. ${ }^{6}$ This legislation gave governors and regents the authority to issue forest concessions for small-scale logging for, respectively, 10,000 ha and 100 ha.

The initial popular response in the regions to these changes was euphoric. Local entrepreneurs, timber brokers, and community elites voiced the opinion that largescale concession holders had never had legitimate claims to the areas they had logged. The expectation was that districts and provinces would finally be able to retain the benefits from the resources extracted from their territory. Those who were anticipated to benefit the most in this context were local residents. The large-scale concession holders were expected to either comply with local demands or be expelled.

The initial euphoria resulted in the proliferation of small logging permits within large forest concessions (Casson and Obidzinski 2002). District and provincial governments granted these licenses mainly with the political objective of appeasing local communities and gaining their electoral support (Obidzinski 2003). The smallscale logging licenses were also used to exert pressure on large-scale concession 
holders to make them more responsive to the districts' and provinces' demands and to extract greater financial contributions, including 'informal' payments.

The growth of small logging concessions continued after the implementation of the regional autonomy policy in Indonesia in J anuary 2001 as districts began drafting their own regulations on community land/forest rights as well as exploitation and use of timber. By 2002, these concessions already covered hundreds of thousands of hectares of forest (Casson and Obidzinski 2002).

\section{Recent policy changes: log export ban, 'soft landing', certification, and money laundering}

The export of logs became profitable again in Indonesia in 1998 following the removal of prohibitive export duties. As a result there was an upsurge in the shipments of logs out of the country. The Indonesian Association of Timber Concessionaires (APHI) and the Indonesian Association of Plywood Producers (APKINDO) saw in this development a threat to the supply of raw material for woodworking industries in Indonesia. They also considered log export as a factor contributing to the eroding competitiveness of Indonesian plywood industries on the international market. As a result, both exerted pressure on forest policy makers in Indonesia to stem the export of logs. Their efforts resulted in the re-imposition of the log export ban in early 2002.

The main argument for the imposition of the log export ban was that it would benefit domestic timber concessionaires and woodworking industries because it would stem the smuggling of logs, thus increasing international timber prices. For a number of reasons, this expectation never materialized. On the one hand, the volume of Indonesian logs (both legal and smuggled) exported to the Asia-Pacific region, while substantial, has simply not been sufficient to influence regional timber prices. On the other hand, the regulation banning log exports from Indonesia has been ineffective in stopping the export of logs. Time and again, press reports have shown that, in direct contradiction to the log export ban, the export of logs from Indonesia continued both 'legally' (i.e., with the use of official documents) and without any documentation at all (Asia Pulse 2003; Kompas 2003b).

Despite the apparent failure of the government policy banning the export of logs, APHI remained adamant about the need to persevere with this policy (Bisnis Indonesia 2003c). It appears, however, that APHI no longer represents a unified stance of forest concessionaires on this issue. Forest concessionaires, particularly in the eastern part of Indonesia, have voiced support for the removal of the log export ban (Bisnis Indonesia 2003d, 2003e).

The most recent, and perhaps most fundamental, policy initiative aimed at bringing the annual harvest in harmony with sustainable yield is the so-called 'soft landing' policy, which involves gradually reducing the national annual allowable cut and distributing this reduction across all provinces and concessionaires. The annual allowable cut (AAC) went from 21 million cubic metres in 2001, to 12 million cubic metres in 2002, to 6.89 million cubic metres in 2003, and to 5.74 million cubic metres in 2004. It is unclear how the new and dramatically reduced AAC quotas proposed by the policy have been calculated. (See Box 1).

Both government and private sector widely accept the probability that the soft landing policy will be extremely difficult to enforce (Bisnis Indonesia 2003a; Kompas 2003a). District and provincial government officials in East Kalimantan, for 
instance, openly state that they will ignore AAC limitations in order to sustain the operations of logging and woodworking industries both for economic (tax revenue, employment) and political (social stability) purposes.

In relation to certification it is notable that companies that hold certification from Lembaga Ekolabel Indonesia (LEI) will receive exemptions from reductions in AAC (Decree of Director General Forest Production No. 02/ KPTS/ VI-PHA/ 2003). The Indonesian government is looking for ways to address the illegal logging issue in the country. It has been supportive of innovative initiatives such as targeting forestry crimes with the newly revised anti-money laundering law (Bisnis Indonesia 2003b; J akarta Post 2003). This matter will be further discussed below.

Box 1. Indonesian policies relevant to forest certification and illegal logging

1. Standard and criteria of SFM (Indonesian Ministry of Forestry decrees No. 252/ Kpts-II/ 1993 and No. 576/ Kpts-II/ 1993 Regulation of Sustainable Forest Management).

As a response to the Earth Summit and the Bali ITTO meeting in 2002, implemented regulations that include the basic principle of sustainable forest management. The decrees do not, however, incorporate social standards as part of the criteria for sustainable forest management.

2. Extraction and trade of ramin (Ministry of Forestry decree No. 168/ Kpts-IV/ 2001).

Permission to harvest and trade ramin will be given to companies having a Sustainable Forest Management Certificate from the Indonesian Ecolabeling Institute, LEl. Ramin is listed in CITES Appendix III, which includes species protected in at least one country that has asked other CITES parties for assistance in controlling the trade.

3. Reduction of the national annual allowable cut (AAC) (Ministry of Forestry decree No. 156/ Kpts-II/ 2003 and Decree of Director General Forest Production No. 02/ KPTS/ VI-PHA/ 2003).

These decrees reduce the total annual allowable harvest to the level of sustainable yield.

4. Illegal logging in the National Parks of Gunung Leuser and Tanj ung Putting (Presidential Instruction No. 5 2001).

It states that the two national parks be protected from illegal logging.

5. Money laundering (Government Law 25, 2003)

The law recognises illegal logging as a predicated crime that can result in money laundering.

6. Forest product administration (Ministry of Forestry decree No. 126/ Kpts-II/ 2003).

This decree establishes administrative procedures to regulate the harvest and transport of logs within Indonesia.

7. Regional forum for SFM certification (Regional Forestry Head decree No. 58/ Kpts/ KWL 4.1/2000, East Kalimantan).

The decree establishes the Regional Forum Certification Working Group to promote forest certification. 


\section{International initiatives against illegal logging and illegal timber trade}

Widespread international concern about illegal logging has resulted in several multilateral and bilateral initiatives aimed at controlling illegal logging. They are reviewed in this section.

\section{Forest law enforcement and governance process}

In September 2001, countries from East Asia and other regions (including Europe and the United States) participated in the Forest Law Enforcement Government (FLEG) ministerial conference in Bali, an initiative designed to establish a framework through which producer country governments could work with one another and with governments of consumer countries to tackle illegal activities in the region. The conference acted partly as a forum for the exchange of views and the dissemination of technical knowledge on a wide range of governance and enforcement issues. Participants included senior officials from forest and related ministries, nongovernmental organizations (NGOs), and industry representatives.

The Bali conference concluded with a ministerial declaration stating that participating countries would, inter alia, 'take immediate action to intensify national efforts, and to strengthen bilateral, regional and multilateral collaboration to address violations of forest law and forest crime, in particular illegal logging, associated illegal trade and corruption, and their negative effects on the rule of law' ${ }^{7}$ The declaration also dealt with the topic of trade in illegally logged timber, including a commitment to 'explore ways in which the export and import of illegally harvested timber can be eliminated, including the possibility of a prior notification system for commercially traded timber' ${ }^{8}$

The conference established a regional taskforce to 'advance the objectives' of the declaration and formed an advisory group of NGOs and industry. Ministers agreed to meet again in 2003 to review progress. Both taskforce and advisory group had initial preparatory meetings in May 2002, and fuller meetings in J anuary 2003. The process has slowed since the J anuary 2003 meeting, which delivered no visible outcomes. To reinvigorate this process, a taskforce and a ministerial meeting are being discussed for 2004 .

\section{China}

China and Indonesia signed a Memorandum of Understanding Concerning Cooperation in Combatting Illegal Trade of Forest Products in December 2002. Co-operation between the two countries may include, but is not limited to

- identification of illegally harvested products and illegal trade;

- support for the involvement of civil society in accordance with respective laws, particularly in monitoring the implementation of compliance verification;

- the joint development of systems for the timely collection and exchange of data on timber trade, related forest laws and regulations, endangered wild fauna and flora, and wood products;

- joint development of effective collaboration between enforcement agencies, and co-operation on training of law enforcement officers;

- enhancement of economic co-operation in the forest sector and facilitation of normal forest trade; and 
- criteria of sustainable forest development and forest certification.

Since stipulation of the memorandum, concrete follow-up does not seem to have taken place.

\section{European Union}

The European Union (EU) has developed an Action Plan on Forest Law Enforcement, Governance, and Trade. One of the proposed components of the action plan is the establishment of a 'legality licensing scheme'. Producer countries that join the scheme will issue legality licenses for wood products, which will be validated by the proposed EU Forest Partnership Agency. Producer countries joining the scheme will benefit from a legality label and promotional actions for their products in the EU.

The EU action plan also includes measures to improve corporate responsibility through voluntary codes of conduct, calls on public procurement agencies to take measures to avoid purchasing illegal timber products, and encourages banks and financial institutions, including export credit agencies, to exercise due diligence when making loans to wood-producing operations, including an assessment of their legality.

\section{Japan}

In J une 2003, J apan and Indonesia issued a J oint Announcement on Cooperation in Combating Illegal Logging and Trade in Illegally Logged Timber and Wood Products. The announcement states that co-operation will focus on the following areas.

- Development, testing, and implementation of systems for verification of legal compliance, to be applied throughout Indonesia and J apan in due course

- Encouraging the involvement of civil society in the effort to combat illegal trade and illegally harvested timber and wood products, and particularly in monitoring the implementation of systems for verification of legal compliance

- J oint development of systems for the timely collection and exchange of data on trade of timber and wood products

- Effective collaboration between law enforcement agencies in the two countries

- Human resource development

\section{Malaysia}

Although Malaysia was involved in the preparatory work for the FLEG conference in Bali in 2001, it decided not to attend the conference and has not participated in the follow-up meetings. Nevertheless, as a result of public pressure from overseas, especially NGOs in Europe, the Minister of Primary Industries, Malaysia, banned the import of round logs from Indonesia on $25 \mathrm{~J}$ une 2002. This action was to complement the log export ban from Indonesia as round logs were being imported into Malaysia at designated timber landing sites. As a result of loopholes in the ministerial declaration, after one year of implementation, the minister on $1 \mathrm{~J}$ une 2003 banned the import of squared logs (large scantlings and squares) larger than 60 square inches. ${ }^{9}$

\section{United Kingdom}

The United Kingdom was the first timber importing country to develop a comprehensive policy on illegal logging and trade in illegal timber products in the 


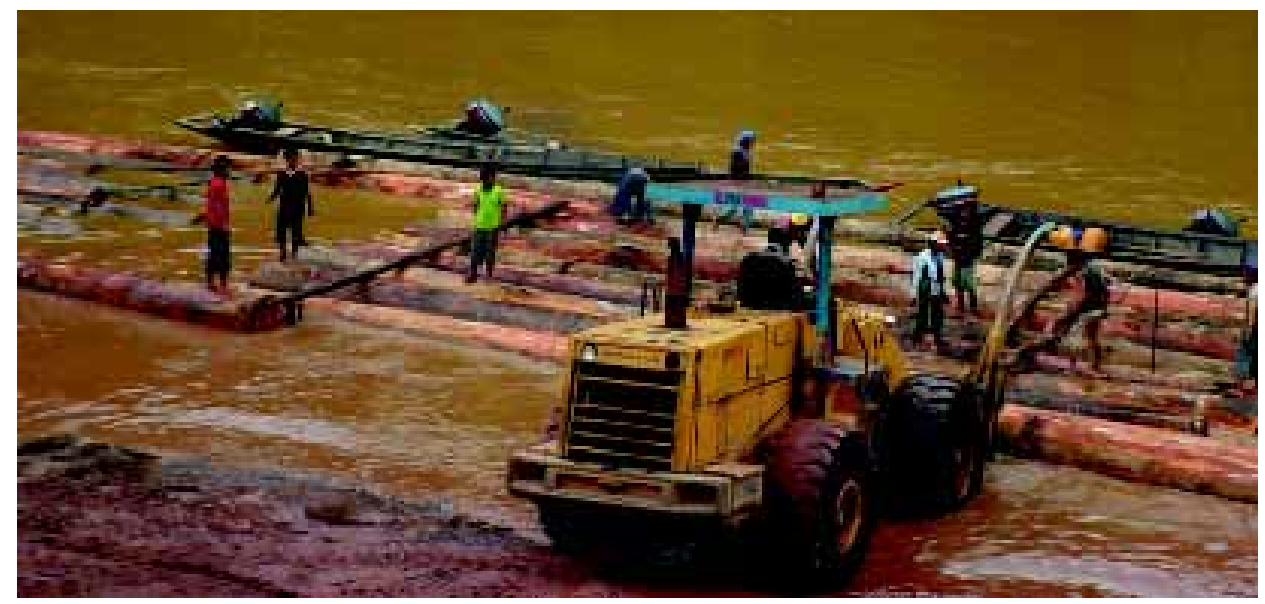

Log rafting and transporting to Plywood mills. (Photo by Yudi Iskandarsyah)

post-Bali Declaration period. The policy includes a domestic procurement policy, support for the EU action plan, support for regional FLEG processes, and a Memorandum of Understanding and an Action Plan on Illegal Logging with Indonesia. The national government procurement guidelines aim to ensure that illegal timber products are not purchased. The procurement policy has three timber product categories: legal and sustainable (preferred), legal and progressing towards sustainability (acceptable), and legal (if others not available).

The Action Plan on Illegal Logging between the United Kingdom and Indonesia is aimed at supporting (i) the involvement of civil society, (ii) the review of forest and forest related legislation, and (iii) the development of capacity to verify legality. The support for civil society includes involvement in the preparation of a work program, identifying civil society's roles in implementation and monitoring of the plan, monitoring of illegal logging, building civil society's capacity, and establishing an independent web site on illegal logging. The review of forest and forest related legislation includes consultation work to arrive at a definition of legality in Indonesia and reviews of decentralisation regulations, customary law, constitution, forest law, rules, regulations and decrees, and trade and transport regulations. In order to develop capacity to verify legality, support is provided for the establishment of a system for independent verification and a chain of custody and tracking system, and the Alliance receives funding for its work in this area. This component also supports the deployment of improved security equipment for forest protection and the clarification of the role of customs departments in Indonesia and the United Kingdom.

\section{United States}

The United States provides funding to the Alliance and has launched a presidential initiative to address illegal logging. The stated goal of the initiative is 'to assist developing countries to combat illegal logging, the sale (including for export) of illegally harvested timber products, and corruption in the forest sector'. ${ }^{10}$ The initiative emphasizes the identification and reduction of threats to protected forest areas and other high value conservation forests from illegal logging. It has four key strategies: 
- Good governance-building country capacity to establish and strengthen legal regimes and enforcement of laws affecting forest management, especially those aimed at illegal logging

- Community-based actions-enhancing community involvement in forest governance and related wildlife issues

- Technology transfer-developing integrated monitoring systems and building incountry capacity to monitor forest activity and compliance with laws, including using remote-sensing and ground-based technologies to monitor changes in forest conditions

- Harnessing market forces-promoting good business practices, transparent markets and legal trade, including in-country capacity to implement obligations under the Convention on the International Trade in Endangered Species of Flora and Fauna (CITES).

Actions in South and Southeast Asia will focus on:

- Community-based forest management and protection

- Promoting eco-governance, transparency, and accountability in the forest sector

- Addressing illegal logging threatening orang-utan habitat

- Follow-up to the East Asia Ministerial Conference on Forest Law Enforcement and Governance held in Bali in 2001.

Some global actions particularly relevant to the present context include:

- Identifying possible actions domestically and in co-operation with timber exporting and importing countries and interested stakeholders to reinforce efforts to eliminate illegal logging consistent with international obligations and administration trade and environmental policies

- Assessing international timber markets to better understand financial investments, supply routes, and transhipment methods

- Addressing forest law enforcement in bilateral agreements, including, where appropriate, within the framework of free trade agreements.

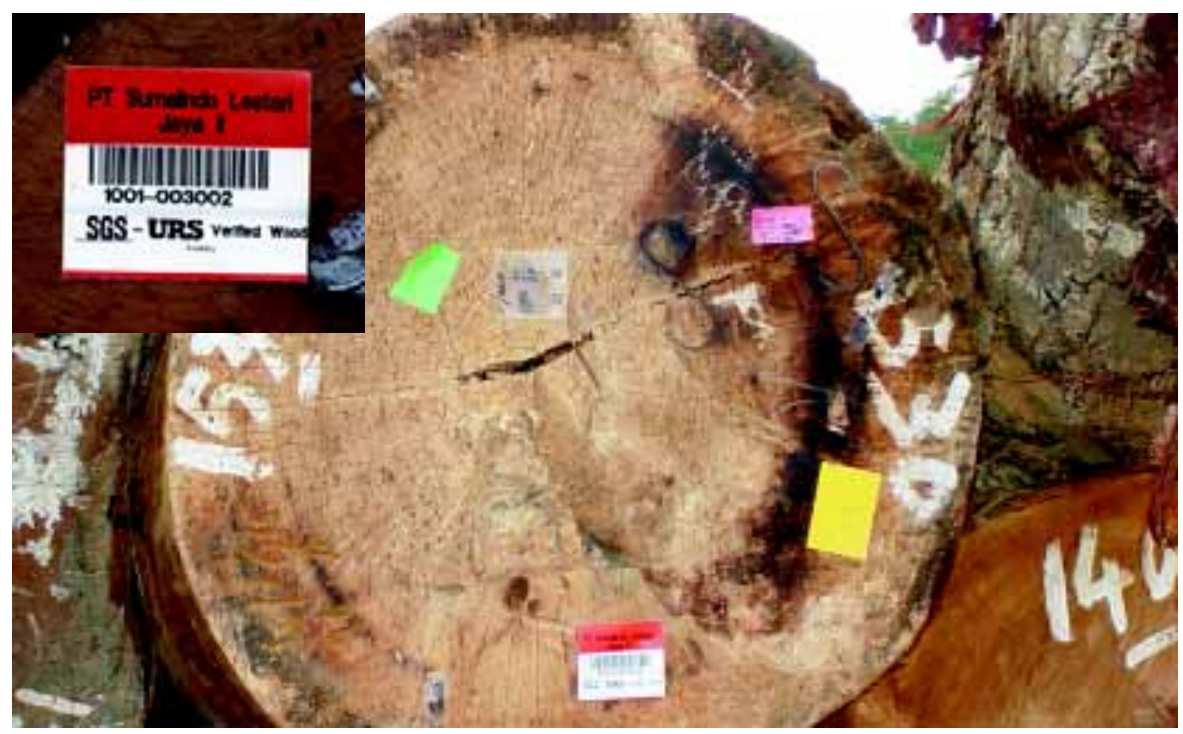

Bar coding used to test the chain of custody $(\mathrm{CoC})$ of logs from forest concessions to wood processing industry. (Photo by Yudi Iskandarsyah) 


\section{Part 2. Taking Action}

\section{The Alliance's Rationale and Strategy}

East Asian markets are the major importers of Indonesian timber products, and they have been largely indifferent to the impacts of their purchases. As a consequence, suppliers exploit weak governance in countries like Indonesia to mine wood through migratory logging and reckless clearing. ${ }^{11}$

The Alliance, therefore, seeks to transform this trade by supporting an expansion of the market for legally verified and certified products in China and J apan. Complementary to the focus on importing countries are the objectives of building the capacity of Indonesian stakeholders to produce verified and certified timber and to improve forest management by promoting the adoption of the concept of high conservation value forests (HCVFs). Investment guidelines to be adopted by financial institutions will also be developed and promoted with the objective of reducing the financial resources available to companies involved in illegal logging and unsustainable forest management.

The strategy of the Alliance and its rationale are summarised schematically in Figure 2, provided by the Alliance.

In summary, the Alliance seeks to:

1. Strengthen market signals to expand certification

2. Increase supply of certified Indonesian wood products

3. Maintain high conservation value forest

4. Reduce investment in companies engaged in destructive or illegal logging in Indonesia

5. Increase industry actors' ability to implement practical solutions to combat illegal logging and achieve sustainable forest management

6. Share the lessons it learned

Part 2 of the report, as well as the logical framework, is organized around these six headings.

The logic of the Alliance is stated in the logical framework (Annex I), which provides a detailed account of the goal, the purposes, and the assumptions of the Alliance. In this framework, after the problem is identified (in this case, illegal logging and destruction of HCVFs), the goal is set and specific program purposes contributing to the achievement of the goal are defined. The delivery of specific outputs contributes to the achievement of each purpose. Assumptions are also made 


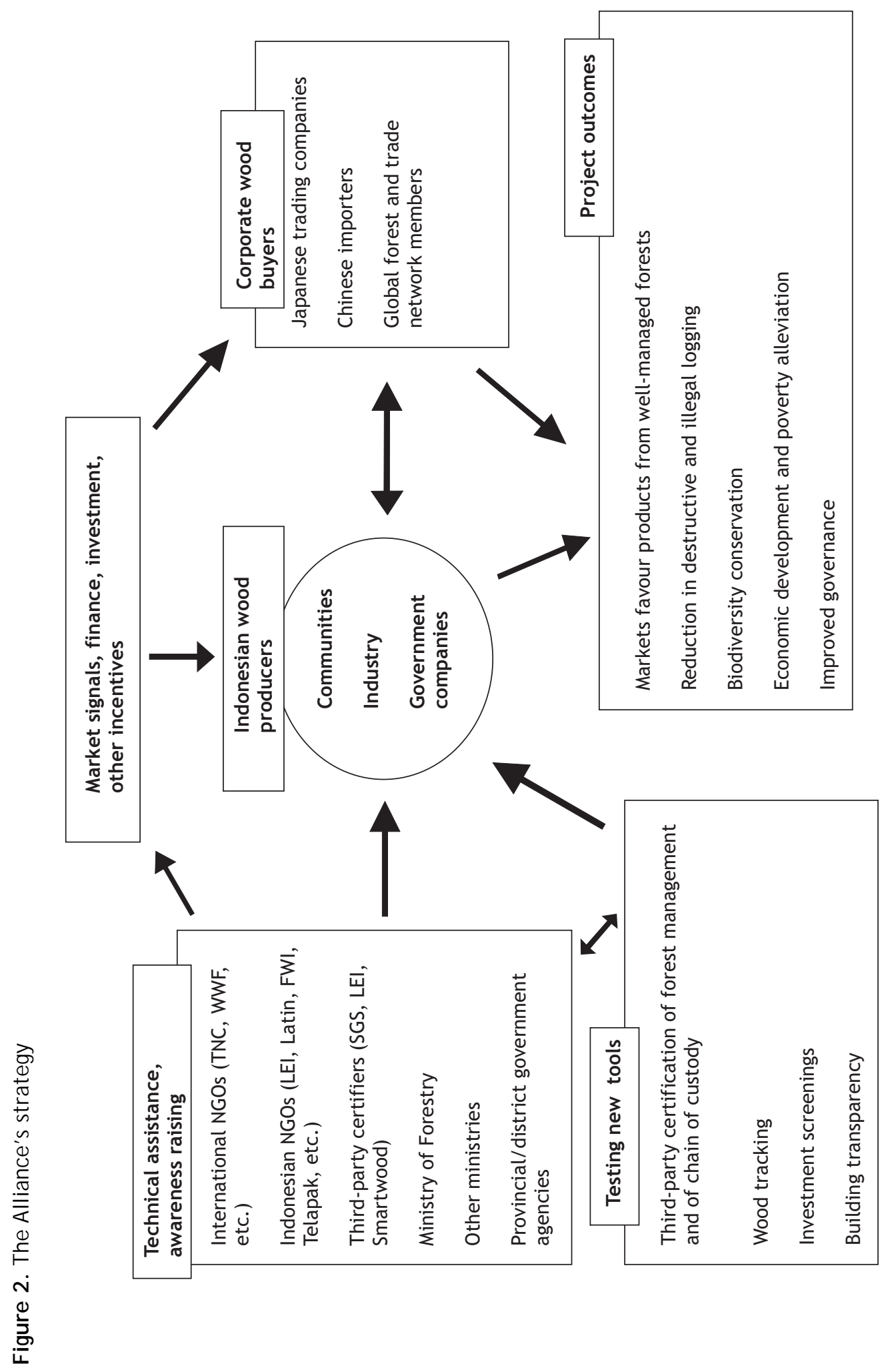


about factors and events affecting the chain between delivery of outputs and achievement of the goal.

The goal of the Alliance, as stated in the logical framework, is to 'promote environmentally appropriate, socially beneficial and economically viable use of production forests and mitigation of threats to high conservation value forests in Indonesia'. Achievement of the goal, in quantitative terms, is defined by the following indicators to be achieved by the end of the third year of activities: ${ }^{12}$

- Timber imports from Indonesia by Global Forest and Trade Network members will be $30 \%$ of total imports in J apan and $15 \%$ in China.

- The volume of exported timber with third party verification of legality in Indonesia will be $30 \%$ of total export volume.

- The volume of third party certified wood will be $10 \%$ of total export volume.

- Four hundred thousand hectares of forests will be managed as HCVF and threats to those values removed, while 1,000,000 hectares will be in the process of zoning.

\section{Strengthening Market Signals to Produce Certified and Verified Legal Timber, and Increasing Its Supply from Indonesia}

\section{Increasing market signals and the stepwise approach to certification}

The purposes of the Alliance is to strengthen market signals to produce certified and verified legal timber, and to increase the supply of certified and verified timber from Indonesia. The Alliance views the transition in international market demand from noncertified to certified timber products as an essential step for eliminating exploitative operations and bringing about a widespread adoption of sustainable management practices in Indonesia, as well as in other countries where TNC and WWF operate. Coaxing a change in unsustainable forestry practices though rising market demand for certified timber products and shrinking demand for noncertified ones is viewed as more effective than simply waiting for the support and co-operation of governments in individual countries. The Alliance therefore seeks to increase the size of the market for certified products by increasing the awareness of the environmental benefits of certification and by 'enticing' producers and traders to join the Global Forest and Trade Network (discussed in more detail below).

Recognition of the difficulties encountered by wood producers to reach the high standards required for certification, together with the potential expansion of the market for legally verified timber, has resulted in increased attention given to a stepwise approach to certification. A stepwise approach means that producers improve forest management practices step by step, starting with the establishment of the origin of the timber and ending with the certification of sustainably managed forest (e.g., ProForest 2003).

Strengthening market signals and increasing the production of verified and certified timber are two components of the Alliance's approach (see Logical Framework, Annex II) that, given the interconnections, this chapter addresses together. 


\section{The Global Forest and Trade Network}

The Global Forest and Trade Network (GFTN) is a WWF initiative seeking to support a stepwise approach to certification and to promote international trade in certified forest products as a means to achieving an improvement in forest management practices. The GFTN is given particular prominence here because it accounts for $53 \%$ of the global demand for certified forest products, while the remainder is traded by non-GFTN companies (32\%), public bodies (14\%), and other entities (1\%) (Asian Timber 2002). Obviously, a company or other organization interested in verified or certified timber does not necessarily need to be part of GFTN, but it may benefit from its recognized 'green' reputation.

GFTN acts as an umbrella organization for forest and trade networks (FTNs) that serve particular regions of the world. The aim of the networks is to raise private sector awareness of the impacts of poor forestry practices and influence polices that govern forest product procurement. Currently, 18 buyer networks of this kind are active mainly in Europe and North America. There are also buyer networks in J apan and Hong Kong. Members are required to develop action plans for the elimination of illegally sourced wood from their supply chains and to increase the proportion of certified wood.

A number of producer groups are in various stages of development in Latin America, West and Central Africa, Eastern Europe, and Southeast Asia. At present, about 500 companies participate in these networks. Increasing attention is being paid to the establishment of FTNs of producers to ensure that supply of verified and certified timber matches demand. Producer FTNs use a stepwise approach to supporting producers in achieving forest certification. Being a member of a producer FTN has the potential benefit of easier access to the international market while the company is preparing to achieve certification.

\section{Promoting certification in China and J apan}

The volume of certified timber products traded in China and J apan is as yet extremely small, as already noted above. However, a few major companies are taking the lead in prioritizing certified timber products. The Alliance hopes other timber trading firms will follow the example set by major companies. In China, the leaders in the purchase and use of certified timber are IKEA, Kingfisher, and Carrefour. These international companies account for about $1 \%$ of the processing and trading of furniture products in China. More importantly, the brands are popular with young Chinese end users of timber products. By working with these and other target companies in China, the Alliance seeks to develop end user awareness of the importance of responsible purchasing of timber products, i.e., certified timber products. Such awareness is seen as a key step in generating a shift towards certification.

In J apan, the Alliance has an additional strategy of working closely with the buyers of Indonesian pulp and paper (particularly from Riau province) in order to exert pressure on the producer companies to follow responsible forestry practices, i.e., cease the conversion of natural forest to pulp and paper plantations. The underlying idea is that such a shift in their business philosophy would cause other companies to follow. One major pulp and paper buyer in J apan-Ricoh-has signalled 
it will take steps to ensure that the products it buys originate from responsible pulp and paper operations.

The Alliance pursues the objective of strengthening the awareness of certification in the Asia-Pacific region through establishment and promotion of GFTNs in China and Japan. By late 2003, 26 companies were engaged for this purpose in J apan, while the membership in Hong Kong's group (which covers mainland China as well) rose to 10 (TNC Fourth Quarter Report 2003; WWF Fourth Quarter Report 2003).

The WWF Programme Office in Beijing is facilitating the formation of a national working group on Forest Stewardship CouncilFSC) certification to develop certification standards in China. So far, two forest management units, one in the northeast and one in the south, have applied for FSC certification. In addition, there are nearly 30 wood processing companies that are FSC chain-of-custody certified. The government strongly supports the process of forest certification in China and is actively promoting it. The National Working Group has received official support from the State Forestry Administration. It held its first meeting in May 2001 and two workshops in November and December 2001.

\section{Certification in Indonesia and Malaysia}

To support producers to achieve certification in South East Asia, WWF launched the FTN producer groups Nusa Hijau (Green Archipelago) in Indonesia and Kumpulan Kazahnah Hijau (Green Heritage Group) in Malaysia in 2003. The goal of these groups is to expand the membership in order to increase the supply of certified and legally verified timber in Indonesia and Malaysia. Both groups and WWF are engaged in a sensitive process of establishing appropriate entry standards for prospective member companies (see below). TNC, on the other hand, has been assisting a number of forest concessionaires in East Kalimantan interested in taking concrete steps towards certification. The effort of the Alliance to promote certification in Indonesia builds on the limited existing base of interest among forestry industry and even NGOs.

Malaysia has developed its own certification system, the Malaysia Criteria \& Indicators (MC\&I), which follows the International Tropical Timber Organization (ITTO) Criteria and Indicators for sustainable forest management. The MC\&I system has struggled to get international acceptance. Therefore, efforts are being made to improve it and bring it in compliance with the FSC system. Some forest concessionaires have chosen to seek FSC certification to gain full access to the certified timber market. Malaysian companies seem interested in certification as a way to maintain long-term access to markets in Europe, the United States, and J apan. Low-cost and noncertified producers in countries such as Indonesia and Cambodia are undercutting the markets in the less green-sensitive markets of China, Taiwan, and South Korea (Mohd Shahwahid 2004). NGO criticism has focused on some Malaysian forestry companies that export noncertified and presumably illegally sourced timber products. Log harvesting in Malaysia is strictly monitored and, therefore, considered mostly to take place legally. Yet, there is a strong suspicion that the timber processed by certain companies is sourced illegally from Indonesia. These supposedly illegal activities are starting to create an image problem for Malaysian timber in general. 
In Indonesia, LEI and FSC signed a J oint Certification Program in 2000. The program is intended to ensure international credibility of the LEI certification scheme. Forest concessions that pass both LEI and FSC requirements will be certified and may use both logos.

Currently, only one forest management company in Indonesia has full LEI-FSC certification: PT Diamond Raya Timber logging concession in the province of Riau. In addition, 24 companies have gained chain of custody $(\mathrm{CoC})$ certificates from FSC, 21 of them teak furniture manufacturers and traders in Java, the others plywood producers in East Kalimantan (PT Intracawood Plywood and PT Tunggal Yudi Sawmill Plywood). Finally, there are eight companies (mostly forest concessions in Kalimantan, Sulawesi, and Papua) that have initiated the process towards certification.

In East Kalimantan, an early certification initiative was initiated by Gesellschaft für Technische Zusammenarbeit (GTZ) in 2000 (Hinrichs and Agung 2000). At the request of the Provincial Forestry Service in Samarinda, GTZ helped set up the East Kalimantan Certification Working Group. By doing so, provincial forestry officials hoped to interest local logging concessionaires in certification. They even issued a regulation to strengthen the working group's legal basis. ${ }^{13}$

Initially, there was substantial interest among forest concessionaires. Working group membership increased from 12 in 2000 to 29 in 2001. As member companies began the required internal self-assessment in preparation for possible future certification procedures, however, it became clear that the gap between their current operations and the standards required by FSC was indeed great. Consequently, many members were of the opinion that, in the unstable political and economic situation of the time, gaining certification was not a priority. Only three have gone forward with the process of certification: PT Sumalindo Lestari J aya II, PT Inhutani I Labanan, and PT Intracawood Manufacturing. The recent dispute between the Ministry of Forestry and PT Intracawood, resulting in the temporary suspension of Intraca's concession permit, has been a serious disincentive for other forest concessionaires considering certification in East Kalimantan.

LEI has introduced forest certification activities in the province of Riau in Indonesia. FSC and LEI auditors granted certification to PT Diamond Raya Timber in 2001. As a result of certification, the Ministry of Forestry granted the company the privilege to self-approve the annual work plan and to harvest ramin (Gonystylus bancanus), which is listed as protected species in Appendix 3 of CITES. ${ }^{14}$ Particularly significant for the company is also the fact that it is not subject to reductions in annual allowable cut required by the national soft landing policy mentioned above.

Certification and verification of the legality of timber are issues hotly debated by a range of stakeholders. Amongst environmental NGOs and certification practitioners, there is an ongoing debate whether the entry requirements for prospective member companies should be strict to ensure seriousness and quality or whether capacity building should be the main objective.

Some Indonesian NGOs are highly suspicious of stepwise approaches to certification. They fear that continuing lack of transparency in Indonesia's timber sector will result in the misuse of even the most well-intentioned programs. These NGOs would like to see companies accountable for past and present violations before they are allowed to produce verified or certified timber. NGOs oppose certification especially because they fear it will legitimise the disregard for customary rights 
under Indonesia's forestry laws. They would like land reform implemented before certification.

\section{Promoting responsible sourcing of timber in Riau}

WWF has so far undertaken a number of concrete activities seeking to promote responsible sourcing of timber in the province. It has held workshops and provided training for local NGOs, government institutions, local universities, and the private sector on issues such as maintaining HCVF, combating illegal logging, advantages of certification, and environmentally responsible regional land use planning. The concept of retaining HCVF is the cornerstone of this initiative, as discussed in a later section. Achievements and baseline in Riau, see Box 2.

Box 2. Achievements and baseline in Riau

\section{Achievements}

- $\quad$ Letter of intent between WWF and APP concerning high conservation value forest, $\mathrm{CoC}$, and resolution of social conflict.

- $\quad$ Riau Andalan Pulp and Paper introduced system to ensure only legal wood is used.

- $\quad$ Promotion of producers' forest trade network. The recruitment process of members has commenced. Workshops have been held to raise awareness and promote certification.

\section{Baseline situation}

- Illegal logging widespread.

- One forest concessionaire holds FSC/ LEl certificate.

- Political uncertainty (conflicting government regulations in land use planning) contributes to forest concessionaires' reluctance to move ahead with certification.

- Most forest concessionaires rely on traditional markets (domestic and China, Japan, Korea, Taiwan).

Representatives of the following companies were interviewed: PT Diamond Raya Timber, Riau Andalan Pulp and Paper (RAPP), and Indah Kiat/ Asia Pulp and Paper (APP). PT Diamond Raya Timber has derived its understanding about certification from its own specialised market orientation. PT Diamond Raya Timber sells most of its timber products to Europe and North America. It has entered these high-end markets for certified timber products on its own initiative and, as such, it is far ahead of any other forest concessionaire in Riau (or in Indonesia as a whole) in meeting international standards for sustainable forest management practices.

The other logging and woodworking companies in Riau know little about certification and feel no particular urge to find out because of their dependence on the Asia-Pacific market, which does not yet have extensive certification requirements in place. They are also discouraged by reports that 'green premiums' are minimal, if available at all. 
RAPP and APP producers in Riau are aware that they cannot meet the FSC requirement stating 1994 as the cut-off date for the conversion of natural forest. As a result, they will not be able to partake in the developments surrounding GFTN. However, for corporate image and for long-term market access (at least to developed markets), responsible sourcing of timber has become an increasingly important issue for the companies. WWF is engaged in a dialogue with RAPP and APP on this issue. (See Table 3.)

RAPP has developed a timber tracking system aimed at ensuring that only legally sourced wood is used in its pulp mill. Societe Generale de Surveillance (SGS) carries out annual audits. WWF and APP signed a letter of intent pertaining to high conservation value forest, chain of custody, and resolution of social conflict. The letter states that APP will

- place an area of 58,500 ha of peat swamp forest near Bukit Batu and Giam Siak Kecil under permanent protection (discussed in a later chapter);

Table 3. Summary of discussions with Riau forestry companies on the issues of certification and illegal logging

\begin{tabular}{|c|c|c|c|}
\hline & & Companies & \\
\hline Main Issue & $\begin{array}{l}\text { Diamond Raya } \\
\text { Timber }\end{array}$ & $\begin{array}{l}\text { Riau Andalan } \\
\text { Pulp and Paper }\end{array}$ & $\begin{array}{l}\text { Indah Kiat/ } \\
\text { Arara Abadi }\end{array}$ \\
\hline $\begin{array}{l}\text { Presence of } \\
\text { Global Forest } \\
\text { Trade } \\
\text { Network } \\
\text { (GFTN). }\end{array}$ & $\begin{array}{l}\text { Important issue } \\
\text { because of } \\
\text { international } \\
\text { marketing } \\
\text { opportunities. } \\
\text { Company not yet } \\
\text { registered as } \\
\text { GFTN member; it } \\
\text { has its own } \\
\text { market. }\end{array}$ & $\begin{array}{l}\text { Large forestry } \\
\text { company is } \\
\text { dependent on } \\
\text { global market for } \\
\text { sales. } \\
\text { Currently, } 22 \% \text { of } \\
\text { pulp and } 23 \% \text { of } \\
\text { paper production } \\
\text { is exported to USA } \\
\text { and Europe. }\end{array}$ & $\begin{array}{l}\text { Has its own market } \\
\text { network. } \\
\text { Company is aware } \\
\text { that GFTN is an } \\
\text { important venue to } \\
\text { increase } \\
\text { opportunities in the } \\
\text { international timber } \\
\text { market. } \\
\text { Geographic } \\
\text { distribution of sales } \\
\text { similar to RAPP's. }\end{array}$ \\
\hline
\end{tabular}

Certification/ Holds certificate responsible from FSC and LEI. sourcing of Costs to meet timber.
Responsible sourcing of raw material/timber has become an important tool in improving corporate image.

Focuses on reducing illegal logging in its concession areas, seeking to avoid purchasing illegal timber and maintaining HCVF.
Price premium is not high-only up to $5 \%$

\begin{tabular}{|c|c|c|c|}
\hline $\begin{array}{l}\text { Obstacles to } \\
\text { achieving and } \\
\text { maintaining } \\
\text { certification } \\
\text { standard. }\end{array}$ & $\begin{array}{l}\text { Social problems, } \\
\text { customary } \\
\text { rights. } \\
\text { Illegal logging, } \\
\text { lack of law } \\
\text { enforcement. }\end{array}$ & $\begin{array}{l}\text { Faces difficulty in } \\
\text { getting certified } \\
\text { because of FSC } \\
\text { principle that forest } \\
\text { plantations shall not } \\
\text { use forest } \\
\text { converted after } \\
\text { 1994. }\end{array}$ & $\begin{array}{l}\text { May be unable to } \\
\text { certify plantations, } \\
\text { as they seem to be } \\
\text { in ex-forest areas } \\
\text { converted after } \\
1994 \text {. }\end{array}$ \\
\hline
\end{tabular}




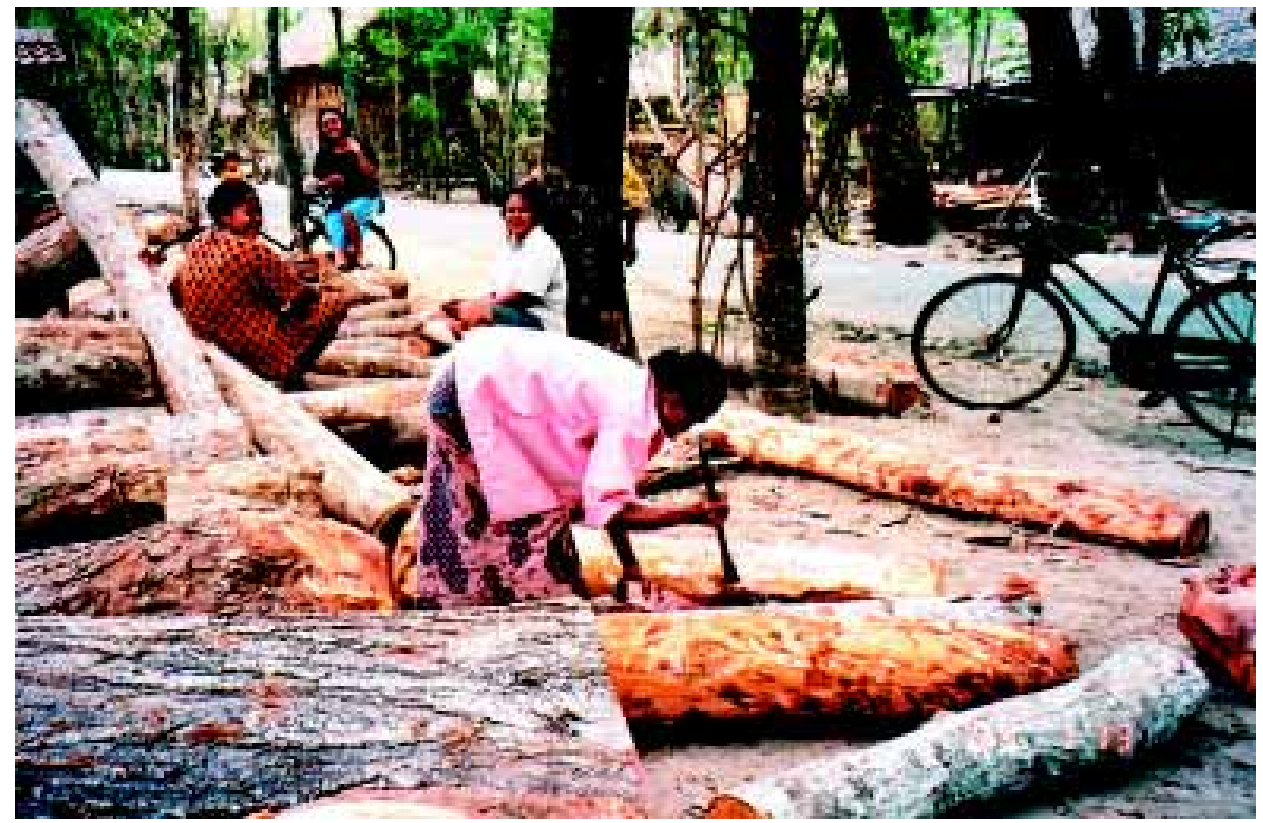

Women removing teak-bark for small furniture industries in Central J ava. (Photo by Ferdinandus Agung)

- fully comply with national laws relating to forests, plantations, and the pulp and paper industry, and it will implement a wood sourcing system to reject any wood not coming from legal harvesting and transport operations;

- resolve land disputes with communities where those land disputes have legal merit, such as because of overlapping permits, or are based on customary law.

\section{Certification and GFTN-community-based forest management in Central J ava and Yogyakarta}

WWF works in the region with a number of NGOs to prepare the ground for more widespread certification activities. The emphasis has been on

- assessing the gap between current teak agroforestry activities by village communities and FSC certification requirements (WWF, Volunteers Alliance for Saving the Nature [ARUPA], district government of Gunung Kidul, Giri Sekar village);

- establishing mutual understanding among stakeholders in the timber trade network (WWF, Association for Study and Social Economic Development [PERSEPSI], district government of Gunung Kidul, Selopuro and Sumberejo village communities, timber traders); and

- performing gap analyses in timber industries for CoC (e.g., ARUPA's study of PT Kontrika Klanten furniture producer and trader).

These initiatives are complemented by training and dissemination activities aimed at building the institutional and operational capacity for certification. ARUPA, LEI, and Gaj ah Mada University have organized workshops and training on communitybased forest management (CBFM). LEI and Gajah Mada University have provided training on $\mathrm{CoC}$. 
Two pilot CBFM areas for smallholder teak growers are active in Wonogiri and Gunung Kidul near J ogj akarta. This baseline study aimed to gather information relating to the following issues: (i) establishment process for community forestry schemes; (ii) organisational arrangements; (iii) CBFM certification; (iv) identification of problems associated with CBFM; (v) origin of raw timber supplies for the smallscale wood-based industry; and (vi) illegal logging.

The communities have been planting teak and mahogany since 1960 in an effort to rehabilitate marginal land in both locations. They managed the plantations in a traditional way without any modern management practices. The furniture companies purchase their raw material from CBFM areas because the price is low, even though the quality of the teak is not as good as that from Perhutani (State Forestry Enterprise). Because the furniture companies involved are small and widely scattered, CoC procedures could be time-consuming and relatively costly.

ARUPA and PERSEPSI, two NGOs supported by WWF Indonesia, are working closely with the communities to disseminate information relating to certification and capacity building. However, the level of understanding about certification is relatively limited. More effort is needed to improve the communities' understanding of the practical aspects of certification and to keep their expectation realistic. The community forest is fragmented in small plots and many farmers worry about the costs of improving their internal performance and securing certification. Achievemetns and baseline in Central Java, see Box 3.

\section{Local government}

The goal of the district forestry administration in Wonosari (J ogjakarta) is to replant more than 15,000 ha of currently bare and marginal land. In this context, forest certification can be seen as an additional incentive to encourage communities to plant trees. Until now, the role of local government has been to form forest farmer groups in order to facilitate communication in the field. The government supports the idea of simplifying the process of marketing the timber from community forests. There are still no specific local government policies recognizing the existence of community forests, however. The local government's actions are limited to providing technical assistance and material support for farmer groups seeking to participate in the National Movement for the Rehabilitation of Land and Forest.

\section{NGOs' perceptions}

NGOs express strong support for CBFM because teak forests are the result of hard work by local communities. They admit, however, that improvements in local institutional capacity will be difficult to achieve in the short or medium term. Still, NGOs think, the process toward certification can be useful as a vehicle for policy reform that eventually will strengthen $\mathrm{CBFM}$, reduce illegal forest activities, and help solve tenure problems.

\section{Researchers' perceptions}

Some academics and independent researchers have a different view of CBFM. They do not support certification for CBFM because, in its current form, certification is a financial and operational burden to the communities. According to the 
Box 3. Achievements and baseline in Central J ava

\section{Achievements}

- $\quad$ NGOs' engagement to support teak planting communities in J ogjakarta and Central Java.

- $\quad$ ARUPA and PERSEPSI deal with the local teak grower community as a support from WWF. They support institutional arrangements as a basic requirement for CBFM certification.

- WWF, LEI, and a local NGO have tested a CoC system for the local furniture industry. The critical links in the wood trade chain have been identified as part of the program. The Alliance has used this activity to increase local communities' understanding of the meaning of $\mathrm{COC}$ and certification, as well as to collect the information required to apply for certification of the $\mathrm{CoC}$ system in community forests and small-scale furniture production.

\section{Baseline situation}

- $\quad$ Sixty-three blocks (292.6 ha) of CBFM teak community forest have been established in Central Java (Faisal 2003).

- Teak farmers' level of understanding of certification is relatively limited.

- The local wood product industry is relatively well informed about the importance of $\mathrm{CoC}$ certification

- Illegal logging on state forest land is rampant but is rather uncommon in CBFM areas.

- The local government is willing to support CBFM. It realises that CBFM provides ecological as well as economic benefits to the region.

respondents, CBFM should be either certified automatically, by virtue of the fact that they are CBFM initiatives, or have financial and other certification burdens reduced.

\section{Certification and GFTN in East Kalimantan}

Awareness and understanding of certification in East Kalimantan are relatively well established but progress has been limited. TNC co-operates closely with the East Kalimantan Working Group on Certification. It supports LATIN and Smartwood for the provision of training. TNC is also working closely with Units II and IV of PT Sumalindo Lestari J aya and PT Gunung Gaj ah Abadi to help them achieve certification. TNC has facilitated market links for PT Sumalindo Lestari J aya in the USA. TNC has also facilitated a number of gap assessment studies by Smartwood and Tropical Forest Trust (TFT) as a preliminary step towards certification.

In addition, TNC has been engaged in a capacity-building effort by providing Geographic Information System (GIS) training for foresters and planners at both provincial and district level. It has conducted workshops on sustainable forest management, benefits of certification, and social aspects of certification for a diverse audience including the private sector, government institutions, and NGOs. Achievements and baseline in East Kalimantan, see Box 4. 
Box 4. Achievements and baseline in East Kalimantan

\section{Achievements}

- Producer FTN outreach in the province has taken shape.

- Collaboration with the Certification Working Group, TFT, and NGOs may be providing some momentum to the process of certification.

- Several memorandums of understanding and letters of cooperation have been signed with partner concessionaires to support forest certification and HCVF initiatives.

- Held multistakeholder forums to discuss problems impeding the process of sustainable forest management and certification.

- Memorandums of understanding with the local government to enhance environmental awareness through eco-regional planning.

- $\quad$ Capacity building by assisting local governments in preparing land use plans based on eco-regional planning.

\section{Baseline situation}

- Provincial authorities are relatively well informed about certification.

- Three forest concessionaires are in the process of certification. In the midst of uncertainty, a number of HPHs believe that, with the support of an international organisation, certification will help them penetrate international markets and they hope government will pay them special attention.

- There are several national and local policies encouraging sustainable forest management but they remain to be implemented.

- $\quad$ lllegal logging remains widespread.

- Political uncertainty (conflicting government regulations) is a major reason for concessionaires' reluctance to go ahead with certification.

- Most forest concessionaires continue to rely on their traditional markets.

\section{Forest concessionaires' perceptions}

Despite a comparatively high level of awareness about certification in East Kalimantan, there is also a sense of scepticism about the practicalities of its implementation. There are several reasons for such doubts. First, about $70 \%$ of timber products from East Kalimantan are destined to J apan and China. As long as there is no tangible sign that these markets are introducing significant changes to their procurement policies in favour of verified and certified timber products, forest concessionaires and woodworking industries in East Kalimantan will probably continue to show reluctance towards certification.

Second, there is legal and political instability in the province, which gives rise to conflicts among various levels of the government bureaucracy and results in business uncertainty. In this kind of environment, forestry companies struggle to maintain basic operations and have a difficult time planning for the long term.

Forest concessionaires also point to the apparent unwillingness of international buyers to pay substantial premiums for certified timber as a factor that is hindering 


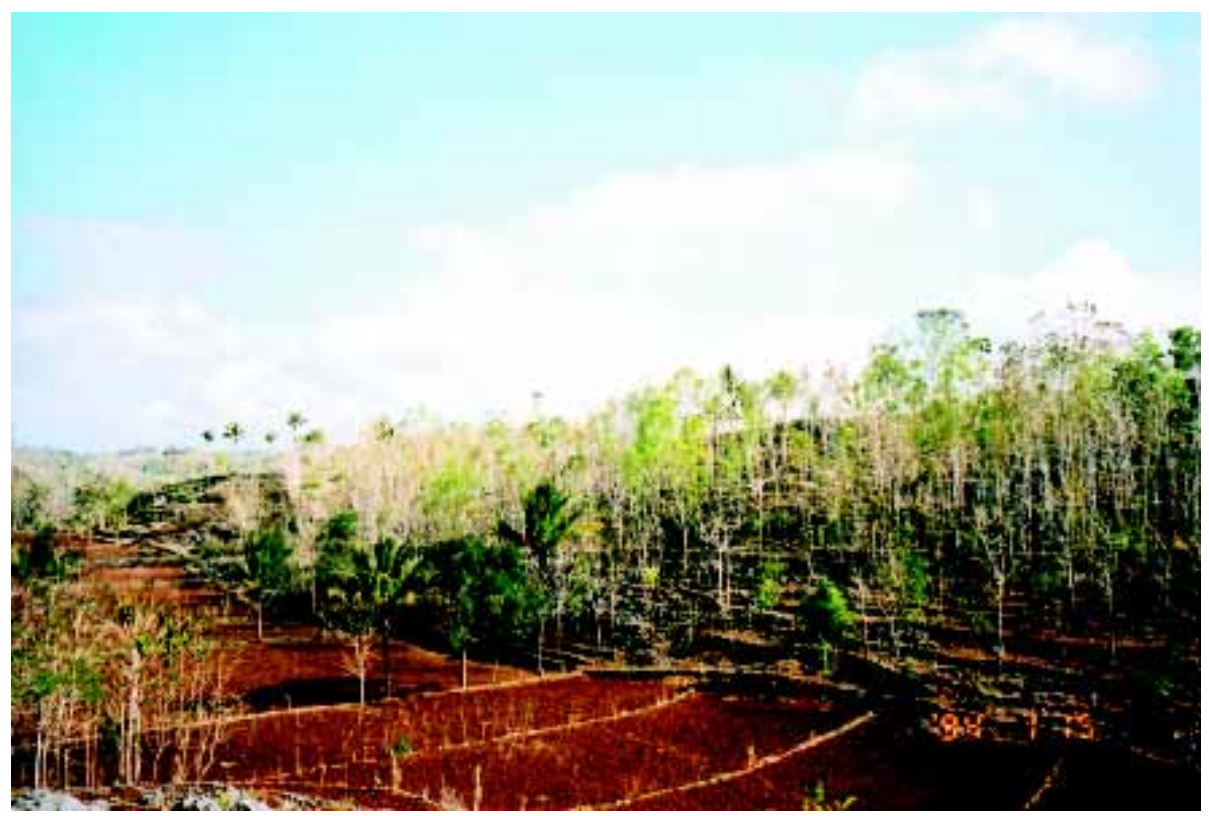

Teak forests belonging to local communities are found on marginal and degraded land in Yogyakarta. (Photo by Ferdinandus Agung)

certification efforts in East Kalimantan. Interestingly, many concessionaires say they are not as interested in obtaining 'green premiums' as they are in having the bureaucratic red tape reduced. Indeed, the Indonesian government has put forth a number of administrative incentives to this effect. For example, companies in the process of being certified may maintain their original annual allowable cut instead of having it reduced as the government planned with its soft landing policy; they also have their annual work plans approved automatically. If maintained, such measures would indeed constitute a significant incentive in favour of certification, but government inconsistency in this and other areas is counterproductive. Despite the promises, companies seriously pursuing certification, such as PT Sumalindo Lestari J aya, still face difficulties and lengthy delays in arranging their annual work plans.

Forest concessionaires view the latest decree concerning AAC reductions as a difficult challenge, but they can see the logic behind the government's pledge to provide exemptions from AAC reductions to companies making progress towards certification. However, the AAC policy and the preferential treatment of companies perceived as being serious about certification have been criticized by the Association of Indonesian Forest Concessionaires. APHI is preparing a study on the volume of timber that can be extracted sustainably from Indonesia's forests. The association hopes the government is willing to increase the AAC for East Kalimantan.

\section{Local government}

Since 1997, the local government has increasingly been exposed to the issue of certification. Since the onset of the process of decentralisation and regional autonomy, however, local government officials have been more interested in struggles for power over forest resources. This resulted in all-pervasive legal and political uncertainty hampering the forestry business. Inconsistencies among 
decentralisation laws No. 22/ 1999 and No. 25/2000 and deconcentration law No. $34 / 2002$ led to widespread administrative overlaps and communication gaps. The conflict of interest behind these conflicting regulations led to a significant increase in the issuance of logging permits.

\section{NGOs' perspective}

NGOs generally do not trust forest concessionaires because of their past poor performance in forest management. Some NGOs believe that a log tracking system needs to be imposed on forest concessionaires prior to any certification process. Such a system, they believe, would help reduce illegal logging, for which concessionaires are considered responsible. NGOs also want to know more about the potential of certification as a tool to solve social problems, especially those stemming from the relationship between forest-dependent communities and logging concessionaires.

Local NGOs generally did not have information about GFTN. When they learned about it, they seemed sceptical as they saw it (as well as certification in general) as a reward to corporations that, according to them, have ravaged the forest and exploited local communities. NGOs would benefit by receiving information on certification and its role in sustainable forest management.

\section{Researchers' perspective}

University researchers expressed the opinion that the prospects of certification remain unclear because forest concessionaires face a multitude of social, political, and regulatory problems. They added there were many NGOs not supportive of forest certification as they feel that certification is just 'forestry business as usual' . Researchers note that to gain greater acceptance of certification by NGOs the NGOs need to be convinced that certification can provide practical solutions to issues such as tenure and indigenous property rights.

\section{Do the assumptions hold?}

In this section, and in similar sections in the following chapters, we consider the assumptions stated in the logical framework. These assumptions are critical to the achievement of the goal and the purposes of the Alliance. An assessment of whether they hold is required in order to manage the program in an adaptive way. If the assumptions did not hold, new activities would be required and/or changes to the purposes would have to be made. The activities of the Alliance have been running for just one year. Therefore, only preliminary observations are possible. Reports for the following years will consider the assumptions in greater detail.

The greatest challenge involved in the market approach adopted by the Alliance is how to significantly increase market demand for certified timber. Two complementary options are available:

1. Self-regulation: the industry undertakes to produce and trade only certified timber.

2. Government intervention: regulations are put in place requiring all timber to be legally verified. 
The approach adopted by GFTN is clearly in the sphere of self-regulation. To result in widespread adoption, self-regulation needs to bring benefits to the companies adopting it. If market demand for the certified product is limited, it is likely that only a small percentage of companies-those seeking access to that market-will adopt self-regulation. The final demand for certified products needs to increase as a result of consumer demand, other social pressures (e.g., from NGOs), or through government intervention. The potential for consumer demand for certified products to increase significantly (especially in Asian countries, but also in other countries) is yet to be demonstrated. The potential for NGOs to affect a large share of the market is yet a matter of speculation, to be tested in part through the work of the Alliance. Government intervention is the third source of potential pressure on the market to embrace verified products. This is the approach taken by the European Union, which is working on a regulation that would stop the import of timber not legally verified through voluntary partnership agreements with producing countries. Obviously, a market-based approach is not completely independent of government regulation, and the next assumption deals with this aspect.

Social and international pressure will lead governments to adopt improved procurement policies.

In Europe, only the United Kingdom and Denmark have a public policy on the procurement of legal and certified timber products. The United States does not have such a policy (FERN 2004). Asian countries do not have public procurement policies. European governments face domestic environmental lobbies stronger than those present in Asian countries. Yet, only two European countries have public procurement policies. This seems to imply that the widespread adoption of public procurement policies by Asian countries may not be readily achievable. However, it should be noted that Hong Kong has introduced architectural specifications for timber. However, it is yet unclear whether these guidelines have implications for the sourcing of verified legal or certified timber.

Buyers assess that it is possible to procure wood from Indonesia responsibly and do not boycott Indonesian products entirely.

Buyers do not seem to be boycotting Indonesian timber products on a large scale. Exceptions appear to be initial pressures from large customers purchasing paper and from timber merchants from the UK and USA, e. g. , International Paper. Procurement of certified wood from Indonesian producers is still very small, perhaps because of lack of supply, given that there appears to be unsatisfied demand for legally verified and certified timber. The size of the demand is unknown, however.

\section{Do the assumptions about increasing the supply of certified products hold?}

Producers that respond to market incentives will be able to achieve certifiable standards of forest management in Indonesia.

All forest concessionaires complain about the initial high costs associated with achieving a certifiable standard of forest management. Certification is unlikely to become a widespread practice as long as green premiums are low (or nonexistent), costs of certification are high, the business environment in Indonesia remains 
unpredictable, and non-eco-sensitive markets are readily available. The latter factor, availability of markets for nonverified and noncertified timber products, is particularly significant. It will determine to a great extent whether a significant number of timber companies will adopt certification. The factors that may contribute to the reduction in the size of non-eco-sensitive markets need to be considered.

Production of verified and certified timber brings better financial returns and market share than doing business as usual.

Currently, this is not the case. Part 1 of the report noted that the financial benefits derived from illegal activities are currently superior to those from legal logging. Verified timber would be more expensive to produce than timber harvested legally but not verified. Buyers in China and Japan do not require verification yet. A pulp company representative noted, however, that the firm was interested in showing the legality of its product because Europe accounts for a relatively significant share of exports. Company officials think that the European market will soon require verification of legality. Therefore, the financial and market access incentives that would lead to an increase in the production of verified and certified timber have yet to eventuate for Asia, but they may be starting to take effect in relation to Europe. To be noted also, some forest concession companies are interested in pursuing forest certification because of a possible reduction in regulatory requirements that would reduce costs.

Medium and small operators seem more interested in price premiums than large companies. The smaller firms face higher per unit costs of certification and international market access. The cost of certification will probably have to be reduced to attract these companies, unless their market access is seriously threatened and they do not have alternative markets. It is obvious that the introduction of public procurement policies and regulations requiring the legal verification of timber products would significantly increase interest in verification and certification.

Voluntary agreements between forest concession holders and local communities can satisfy certification principles on tenure and indigenous peoples' rights.

One factor in determining whether this assumption holds is depth of commitment on the companies' part to address tenure and rights issues. The companies' commitment to resolving this issue, however, hinges on government policy on land tenure and the extent to which the companies see respect for customary forest use and access rights as central to maintaining good relations with local communities and avoiding disruption because of social conflicts and disputes. Some, particularly representatives of NGOs, are of the opinion that certification actually endangers indigenous peoples' rights because voluntary agreements are 'quick fixes' whereby the companies gain from certification while the communities remain disenfranchised.

In East Kalimantan, PT Sumalindo Lestari J aya and TNC have established a stakeholder forum to resolve the conflicts between local people and the company. This experience will be useful in testing whether voluntary agreements can be developed that satisfy certification principles on land tenure and indigenous peoples' rights. 


\section{Financial Measures to Promote Responsible Forestry and to Reduce Illegal Logging}

\section{Can financial tools help?}

The Alliance proposes to reduce the financial services available to companies engaged in the destruction of forests. Activities, as currently planned, focus on developing a set of 'forest-friendly' tools to screen investments and on promoting the adoption of forest-friendly investment policies and screening tools by the East Asian financial sector.

Companies rely on banks for loans and other financial services to finance and operate their business. Financial services may also be used to launder money derived from illegal activities. Some companies investing in the forestry and agricultural sectors rely on credit provided by export credit agencies (ECAs), mainly from developed countries.

It may be hypothesized that if financial institutions did not provide credit and other financial services to companies involved in forest conversion or illegal activities, these firms would not be viable. Therefore, they would either fold or stop forest conversion, unsustainable forest management, and illegal activities.

Let us consider these hypotheses in relation to illegal logging from the perspectives of customers and financial institutions. The arguments discussed below apply equally to companies involved in forest conversion affecting HCVF.

Because large companies make significant use of financial services, we start by considering their case. A large company involved in illegal forest activities may be expected to engage in this behaviour because the business is profitable and it does not carry a reputation risk, i.e., the company is unconcerned. ${ }^{15}$ The denial of financial services could affect the company's profitability and certainly its capacity to operate. Hence, we can expect the spurned company to seek financial services from another financial institution. Whether the company will be successful in developing alternative arrangements with financial institutions depends on the financial services sector. For large investment projects, such as in pulp and palm oil production, most financial arrangements involve syndicated revolving loans, where one or two international banks do the screening and set the standards. Some large international financial institutions have adopted investment guidelines that take into account environmental impacts (such as those developed by WWF and the Equator Principles ${ }^{16}$ ), and if more leading banks followed suit, it would become difficult for a large company to arrange alternative sources of financing. Therefore, the company would have three alternatives: (i) source capital and services through its conglomerate structure, ${ }^{17}$ (ii) stop illegal activities, or (iii) close down its business. ${ }^{18}$ If the company modified its operations to become legal, ${ }^{19}$ illegal logging would decrease, assuming other companies did not increase illegal logging. The latter would also decrease if the company stopped operations and its illegal logging activities and sourcing of illegal timber were not replaced by other companies.

Small companies are most likely to make limited or no use of financial services. If they do use financial services, their behaviour and options can be expected to be similar to those described above. If small companies are numerous, they are also 
difficult to monitor because of the large number of operations to be assessed and the related transaction costs.

This analysis indicates the following.

1. Large companies, especially those in pulp and paper and palm oil production, are more likely to be affected by financial screening initiatives. The Alliance correctly focuses on large businesses.

2. A reduction in the availability of credit for unsustainable and/or illegal forest activities may reduce the occurrence of these activities. However, the extent to which this leads to an overall reduction in deforestation depends on whether other (smaller) companies, or other land clearing activities, take over activities or areas abandoned by the companies that have been 'screened out'.

Let us now consider the perspective of the financial services industry. It would implement voluntary screening if that reduced financial risk (i.e., increased profits) and/ or reduced reputation risk (i.e., it would maintain or improve market share). Several large international financial institutions are obviously concerned about financial and reputation risks, as demonstrated by the international institutions adopting the Equator Principles. Large financial institutions are likely to do business with large forestry and plantation operators, possibly for loans and other services. The adoption by large financial institutions of environmental investment screening would depend on the benefits associated with the practice. For example, if the screening is costly and the reputation risk high, they might stop providing services, such as loans, to forestry operations. Obviously, an alternative situation is one in which it is difficult to monitor the services financial institutions provide, resulting in limited reputation risk. Lack of adoption of screening procedures results in limited image risk (but possibly increased financial risk) unless there is outside pressure for companies to adhere to industry standards. Indeed most screening processes involve an audit, commitments from the borrower, and periodic monitoring.

It can be expected that international financial institutions are more concerned about reputation risk than their national counterparts in countries where stakeholders' and clients' sensitivity to environmental issues is lower, such as Indonesia. Institutions with better corporate governance can be expected to be more averse to financial risk. Firms with better corporate governance may also be expected to be in countries with more developed regulation of corporate governance.

Institutions from countries with weak environmental constituencies appear to provide a relatively significant amount of credit for forestry and palm oil plantation projects. For example, funding has been made available from China for a new pulp mill in South Kalimantan, and Malaysian banks are the second largest providers of credit to palm oil development in Indonesia. The Alliance should consider establishing a dialogue with relevant financial institutions in Asian countries and assessing their interest in developing environmental screening tools.

\section{Indonesian forestry and finance}

Plywood, pulp and paper production accounted for about $68 \%$ of total use of roundwood equivalent in 2001. The quantity of illegal timber used by these producers is uncertain but it can be expected to be significant given the high ratio of illegal to legal timber production in the country. It has been estimated that about $40 \%$ of the timber used for pulp production was from 'undocumented' sources (Barr 2001). 
Obviously, influencing the plywood, pulp and paper companies, as attempted for example by WWF through its dialogue with the creditors of Asia Pulp and Paper, could have a significant impact on the levels of illegally harvested timber.

J ust four conglomerates control pulp and paper production. The firms involved in plywood production are considerably more numerous. In 1996, there were 120 large firms, most located in Kalimantan, according to Statistics Indonesia (BPS) data analyzed by the USAID programs Environmental Policy and Institutional Strengthening Indefinite Quantity and Natural Resources Management. Currently, there are about 100 firms. ${ }^{20}$ Independent monitoring of the legal log intake and financing operations, including the names of institutions providing financial services to plywood, pulp and paper firms would be a viable, albeit complex, endeavour, particularly with regard to plywood. A similar monitoring arrangement could be considered for conversion projects with potential impacts on HCVFs.

\section{Export credit agencies and money laundering}

ECAs are public institutions that provide credit and financial guarantees to national companies to support their overseas trade and investment activities. Currently ECAs are not subject to any binding environmental, human rights, or development guidelines, except for the USA's Ex-Im Bank and Australia's Export Finance and Insurance Corporation (FERN 2002). ECAs operate in all 15 EU member states ${ }^{21}$ and have been involved in a number of projects with environmental impacts including in forestry.

A coalition of NGOs, the ECA Reform Campaign, has been active since 1996. The Alliance should consider whether it has a comparative advantage to carry out activities relating to ECA reform. Its involvement in issues relating to ECAs may strengthen the existing NGO campaign. The Alliance should also consider starting to monitor large-scale forestry investments in Indonesia, and the role ECAs play in funding them, given that a large-scale project can impact on hundreds of thousands of hectares of forest.

The implementation of money-laundering legislation is one way to create a financial disincentive for illegal logging, that is, to increase the cost of noncompliance. Money laundering is any transaction that involves criminal proceeds and seeks to disguise their illegal origin. Money laundering entails three distinct stages: (a) displacement of funds into a business; (b) layering of funds through various transactions in order to conceal their origin; and (c) integration, in which the funds are integrated into legitimate businesses (Patlis 2003b).

In 2003, CIFOR successfully worked with the Financial Transaction and Report Analysis Centre of Indonesia to have illegal logging included as a predicate offence in Indonesia's revised anti-money-laundering legislation. Whether the law can be implemented effectively remains to be tested. Limited information is available about the chain of financial transactions that parallel the log chain from forest to market and about the points along the log chain where illegality occurs. Financial enforcement authorities need an increased understanding of these aspects to enforce money-laundering legislation, given that money laundering follows from the commission of a previously predicated crime.

As noted in the previous section, small forestry operations make limited use of financial services. This circumstance, and the high costs associated with monitoring a large number of small transactions, makes it likely that money-laundering legislation 
could be used effectively only in relation to the operations of large companies. These are the same companies that are likely to come under the scrutiny of the environmental screenings discussed above.

The Alliance may wish to assess whether supporting the implementation of money-laundering legislation would strengthen the incentives for large companies to use legal timber.

\section{Do the assumptions hold?}

Reduction in loan availability and access to financial services is a deterrent against illegal logging and unsustainable forest management.

In theory, reduced availability of financial services is a deterrent against illegal logging and forest conversion with regard to large companies, and especially those involved in milling operations. The deterrence may not be as strong for smaller companies and forest concessionaires without mills, which rely on financial services to a much smaller extent. A focus on large companies, as adopted by the Alliance, has a significant effect as large firms account for a considerable share of the market.

It remains to be assessed whether financial screening is better suited to shaping proposed plantation expansion, and preventing clearance of HCVFs, than dealing with illegal logging. In relation to illegal logging, financial screening could be coupled with the implementation of anti-money-laundering legislation. Debt restructuring, such as those done by APP and Asia Pacific Resources International Holdings Limited (APRIL), also present opportunities to introduce environmental covenants.

A critical mass of institutions will be persuaded to adopt such screenings, so that projects cannot simply be switched to financiers without such procedures.

This assumption remains to be tested. Particular attention needs to be devoted to the potential relevance of achieving a critical mass of international and domestic institutions, particularly those in countries such as China and Malaysia.

Lack of investment screening tools is the main reason for indiscriminate financial support for forest-based companies.

Financial screening guidelines provide a tool to institutions concerned about the implications of forestry lending operations. Some financial institutions have sought WWF support in operationalising their own forest sector investment screening policies. Considerable work needs to be done to interpret and apply the broad statements of principle in these policies to the specific circumstances of Indonesia. A second issue is how to increase the concern of other financial institutions about forestry problems to ensure widespread adoption and implementation of forest friendly investment guidelines.

Projects that involve illegal or reckless logging or the clearing of HCVFs carry higher financial and image risk to financial institutions than projects employing best practices.

Financial institutions have become more aware of the potential risks involved in forestry lending as a result of several NGO campaigns and initiatives such as the development of the Equator Principles, as well as the much publicized debt restructuring process involving APP. Increased awareness, however, does not 


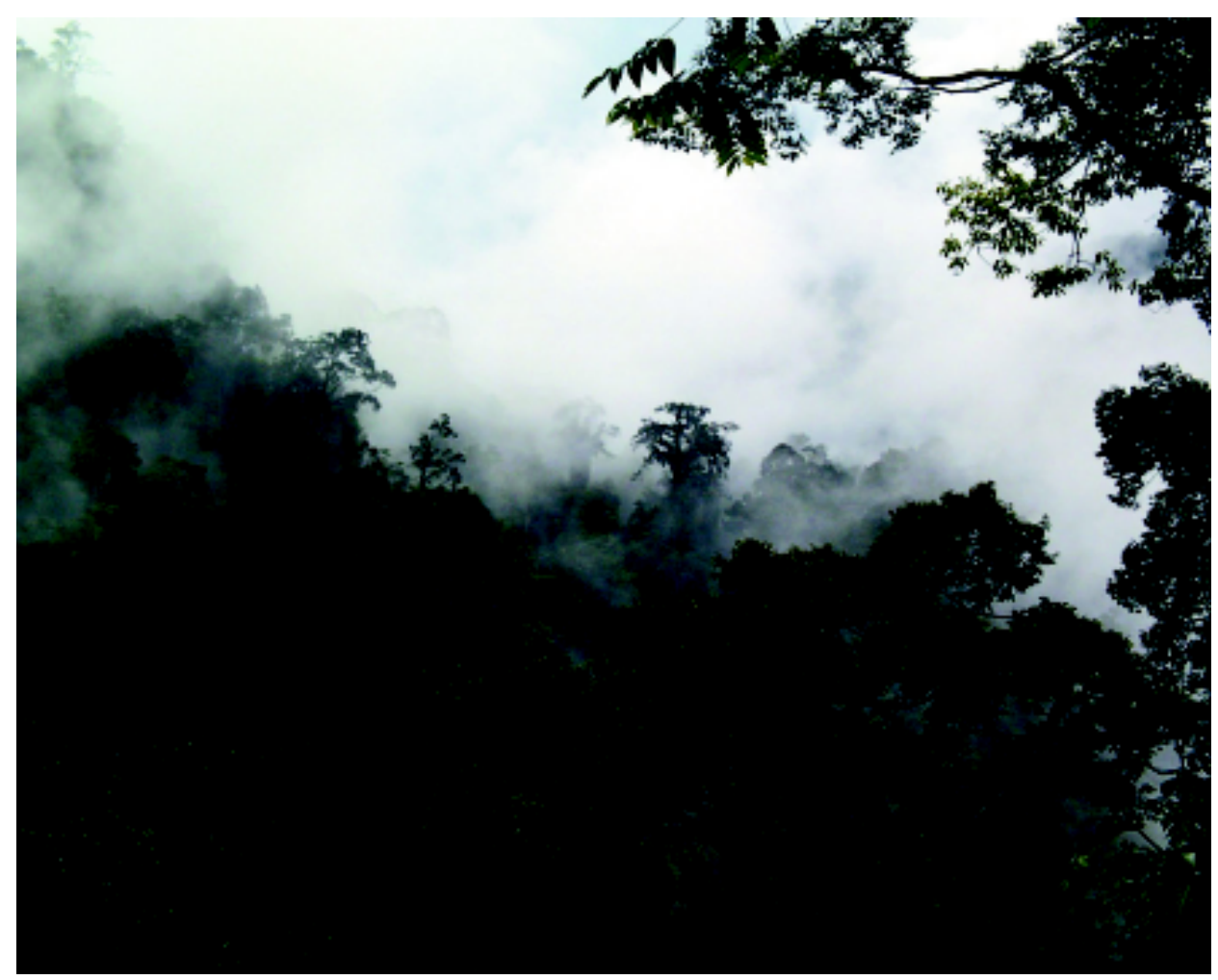

Tropical lowland dipterocarpacae with high biodiversity require carefuly management to avoid destruction. (Photo by Ferdinandus Agung)

necessarily mean increased concern about the potential environmental impacts of forestry related financial operations. Concern may be determined by the following factors: (i) awareness and understanding of a problem, and (ii) realisation that the problem will impact negatively on the company itself. For the assumption to hold, there needs to be continued scrutiny, and eventual exposure, of the operations of forestry and plantation companies and their sources of financial capital.

\section{Maintaining High Conservation Value Forests}

\section{What are HCVFs?}

The Alliance seeks to mitigate threats to HCVFs in Indonesia. FSC Principle 9 defines HCVFs as forests with environmental, biodiversity, landscape, and socio-economic values of critical importance. The same principle identifies six general features characterizing HCVFs. According to these principles, HCVFs are

- forest areas that contain globally, regionally, or nationally significant concentrations of biodiversity values;

- forest areas that contain globally, regionally, or nationally significant, large landscape-level forests or that contain management units where viable populations of most, if not all, naturally occurring species exist in natural patterns of distribution and abundance; 


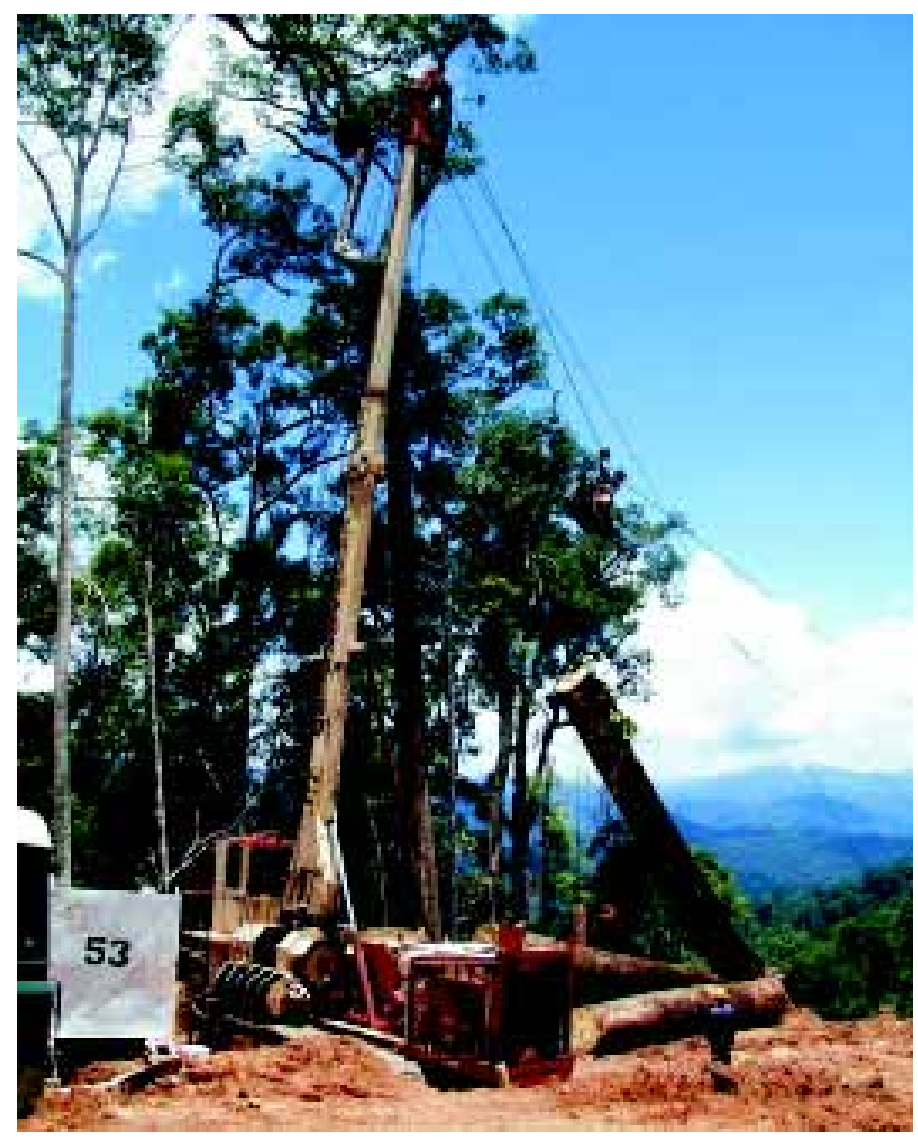

Reduced Impact Logging with skyline system to avoid destruction of High Conservation Value Forest. (Photo by Ferdinandus Agung)

- forest areas that are in or contain rare, threatened, or endangered ecosystems;

- forest areas that provide basic services of nature in critical situations;

- forest areas fundamental to meeting basic needs of local communities; or

- forest areas critical to local communities' traditional cultural identity.

Any forest matching any one of the above characteristics can be considered a HCVF (J arvie et al. 2002; J arvie and J eyaraj 2002).

\section{HCVFs in Indonesia}

Not all natural forest is HCVF. The increasing scarcity of primary lowland forests, however, makes it more likely that primary forests will qualify as HCVFs. Secondary forests, even those subjected to several logging cycles and thus partly degraded, may still be classified as HCVF because they may continue to harbour a significant level of biodiversity and perform important ecological and other functions. Swamps are also high on the list of potential HCVF sites.

ProForest, with a contract from the Alliance, has developed a toolkit for the identification and management of HCVF for use by forest products companies. The challenge now is to identify HCVFs and especially to ensure that they are maintained as HCVF. 


\section{Riau}

In Riau, WWF has focused on the Tesso Nilo Landscape as the backbone for HCVF efforts in the province. The landscape plan envisions the establishment of a set of interconnected conservation areas covering key HCVF locations, including Tesso Nilo proper, which contains the largest compact area $(150,000$ ha) of lowland rainforest in Sumatra, submountain and mountain forests in Bukit Tigapuluh and Rimbang Baling, and peat swamp forests in Giam Siak Kecil, Bukit Batu, and Kerumutan. In addition, PT Diamond Raya claims that an Institut Pertanian Bogor study has concluded the entire area of Diamond Raya's forest concession is HCVF.

WWF is engaged in negotiations with the private sector and government institutions to secure the conservation of the Tesso Nilo forest area. Forest concessions cover most of this lowland forest and there are plans for timber and oil palm plantations once logging concessions expire. Therefore, WWF is trying to develop a compromise acceptable to all stakeholders. The key stakeholder here is the pulp and paper producer RAPP.

WWF continues to monitor closely the situation in Bukit Tigapuluh and Rimbang Baling, officially recognized protection areas in the Tessonilo complex. WWF has completed finer scale analysis of high conservation values in one forest block in Giam Siak Kecil and Bukit Batu protected areas. The block is within the timber plantation concession of PT Arara Abadi/Indah Kiat/ APP. Giam Siak Kecil has an area of 50,000 ha, whereas Bukit Batu covers 21,500 ha of the same peat swamp forest ecosystem. Having this block of HCVF retained as natural forest, rather than converted to acacia plantations, has been among key strategic objectives of WWF in Riau. In August 2003, WWF succeeded in convincing APP to sign a memorandum of understanding in which the company committed itself to conserving the protected areas and a temporary logging moratorium on an additional 8,500 ha of forest adjacent to Giam Siak Kecil and Gunung Batu. As compensation, Iand swap arrangements are under consideration. Following the relative success of working out an agreement for Giam Siak Kecil and Gunung Batu, WWF has initiated discussions with APP for a similar arrangement for a Kerumutan peat swamp forest area in southern Riau province (Purwo 2003).

As work to identify forests with high conservation values proceeds, WWF has undertaken steps to prepare the ground for the incorporation of these areas into the framework of spatial planning in Riau and its districts. WWF has held workshops on HCVFs for an audience comprising members of the private sector, provincial planning board, NGOs, and local universities. In co-ordination with a local NGO framework and by providing assistance to the working group at the provincial planning board, WWF has made progress in advancing the agenda of turning Tesso Nilo from production into conservation forest.

\section{East Kalimantan}

In East Kalimantan TNC has undertaken eco-regional planning that identifies priority conservation areas. Using a scoring system that accounts for an array of values, TNC has developed a province-wide network of eco-regional units to be targeted for conservation. The resultant eco-regional program was presented through a 'road show' to both provincial and district audiences. There is interest among 
forestry officials and government planning bodies and potential to advance the HCVF program through capacity building and technical (GIS) assistance.

While there is potential for HCVF development in East Kalimantan, the issue is new in the area. Currently, there is only one officially established HCVF in the province. With TNC'S assistance, PT Sumalindo Lestari Jaya Unit II set aside as HCVF 50,000 ha of its forest concession on the upper Mahakam. TNC has also signed a letter of intent with PT Intracawood to help the company identify and establish HCVFs in its concession tract.

In addition to these two areas, two other locations can be described as being in advanced stages of progress towards HCVF designation. One is in the north-central part of the PT Gunung Gajah Abadi forest concession, where TNC discovered a large population of orang-utans in late 2001. Discussions and negotiations about introducing conservation measures in this region are taking place. The other area, known as Lesan, covers about 12,000 ha northeast of the PT Gunung Gaj ah Abadi concession. Similarly to the PT Gunung Gaj ah Abadi concession, Lesan is a prime orang-utan habitat. Provincial planning maps, however, showed Lesan as part of the conversion forest. TNC has succeeded in having the status of the area changed from conversion to conservation by working closely with the district planning board in Berau. Once approved, the district spatial plan of 2003 will have to be incorporated into the provincial spatial plan.

TNC has made significant progress in advancing HCVF planning in Berau. By maintaining close working relations with the district planning board (initiated by the EU Berau Forest Management Project), the district has the data and skills to prepare arguably the best district development maps and plans in the province. Perhaps most significantly, the new 2003 district spatial plan features a 10\%increase in Berau's conservation area to the total of 616,000 ha.

\section{Views on HCVFs of government officials, NGOs, and the private sector}

In Riau, the private sector (particularly APP and RAPP/APRIL) has shown interest in HCVF, hoping that it may lead to some compromise formula that would allow the companies to retain their international markets and gain certification by demonstrating responsible forest practices. In fact, RAPP claims that most of HCVF requirements are routinely fulfilled by standard conservation practices in its timber plantation concessions. For both companies the main motivation for co-operation on the issue of HCVF is a positive corporate image. The companies appear to think that consumer pressure for environmentally responsible pulp and paper operations will continue to rise. The companies are automatically disqualified from FSC certification because they engaged in the clearing of natural forest after 1994.

Provincial forestry officials in Riau have only recently heard about the concept of HCVF. While they support WWF activities promoting HCVFs, they point to the fact that such activities lack a legal basis in Riau and indicate that this issue needs to be addressed urgently. WWF has made some progress in linking the development of HCVFs with the spatial planning in the province. Planners in Pekanbaru, however, think that district planning boards need to be involved in the process more actively.

NGOs are generally supportive of WWF's HCVF initiative, although they voice concerns over the transparency of the process leading to the agreement with APP. 
They look forward to seeing the practical implementation of this memorandum of understanding. They also wish to be more involved in the discussions on HCVF.

As in Riau, the HCFV initiative in East Kalimantan is new. As a result, the knowledge about HCVF is still limited. Most forest concessionaires co-operating with TNC and its partners have heard about the concept and tend to assume that it stands for a form of 'protection forest' (hutan lindung). Awareness about HCVF among province and district forestry and spatial planning institutions still needs to be developed. Likewise, the majority of NGOs both in Samarinda and in the districts, do not understand the concept of HCVF. If it is explained, some reject HCVF designation as a tool to legitimize the operations of forest concessions that, in their view, must be completely overhauled. TNC has developed a communication strategy that includes a web site, a monthly bulletin, a monthly section in the main daily, Kaltim Pos, and co-operation with a radio station in Samarinda. These efforts may build greater awareness in the province about HCVF.

\section{Do the assumptions hold?}

Policy wins (adoption of policy by key players) can lead to management and maintenance of HCVF.

This scenario appears to be valid. The governor of East Kalimantan recently established a commission on orang-utans in the province. The head of Berau district is expected to issue an instruction protecting the Lesan area as orang-utan habitat. This and other changes in Berau's 2003 district land use plan will increase the district's protected area by 10\% Once the 2003 district spatial plan is approved, this will be the first instance in East Kalimantan of a HCVF area being incorporated into district level plans. It will send a decidedly positive signal across the province. As always, however, the key issue is practical implementation and enforcement of these decisions. While the $10 \%$ increase in Berau's conservation area between 1997 and 2003 is a good achievement, it will be difficult and time consuming to impose the conservation status on new areas designated for conservation. Currently, most of them are under forest concessions. In Riau, it also remains to be seen how APP implements the commitments it made in its memorandum of understanding with WWF.

In East Kalimantan, an area of HCVF amounting to 50,000 ha has been established in the concession area PT Sumalindo Lestari J aya II. The forest concessionaire PT Intracawood is in the process of identifying a HCVF area. Areas of HCVF have been identified in the Tesso Nilo area (Riau) and in East Kalimantan.

Use of the toolkit for HCVF will improve conservation.

The PT Sumalindo Lestari J aya II forest concession in East Kalimantan, where the HCVF toolkit is in use, has arguably the best-maintained forest in the province. The main constraint in evaluating this assumption is that the above answer is based on a single forest concession case where HCVF conservation has been adopted. Most HPHs have scarcely heard of HCVF, not to mention having or adopting the HCVF toolkit. 
Explicit public commitment from the local government to good management of HCVF will result in better management of HCVF.

The aforementioned road show has generated interest in eco-regional planning among district and provincial administrations. No direct adoption has yet taken place. Berau is closest to incorporating HCVF (Lesan) into its land use plan. The implementation of a similar plan in East Kutai (orang-utan area in PT Gunung Gaj ah Abadi concession) is further behind. Other districts are likely to follow, especially if the interest is sustained by quick provision of technical assistance. Local governments' support for HCVF is still to be developed in Riau.

Plantation and processing companies that maintain HCVFs can obtain alternative plantation land or sources of fibre.

This is the assumption behind the memorandum of understanding signed by WWF and APP in April. APP has set aside 58,500 ha of peat swamp forest for HCVF and it is hoping to get an equivalent area from the provincial government in other locations or purchase fibre at affordable prices from elsewhere. WWF is expected to facilitate this land swap process. It is too early to say how successful and effective this process can be.

\section{Building Capacity to Reduce Illegal Logging}

\section{Timber tracking and verification in perspective}

The Alliance seeks to support forest industry actors in the implementation of practical solutions to combat illegal logging and achieve good forest management. Although forest concessionaires generally understand the requirements of Indonesia's log administration system, ${ }^{22}$ the fact that significant amounts of timber are extracted and processed illegally all over Indonesia has resulted in a lack of credibility of that system in the market place.

Forest concessionaires that sell to eco-sensitive markets need to have a thirdparty-verified log tracking system to maintain market access. About 25 processing companies already hold $\mathrm{CoC}$ certificates. Two are connected to forest concessionaires, namely, PT Diamond Raya Timber and PT Intracawood. The others are not. ${ }^{23}$ To increase the number of concessionaires producing legally verified timber and adopting a CoC system, a clear definition of legality needs to be developed and the costs of legal verification and timber tracking have to be minimized. This is the task the Alliance is seeking to undertake. The component is still in its preliminary phase, therefore only limited observations can be made at this stage.

\section{Testing a new system in East Kalimantan}

TNC is testing a system to verify the legality of timber in a pilot area in East Kalimantan. This work involves development of an auditable definition of 'legal timber' and of a cost effective tracking system.

An auditable definition of legal timber, accompanied by a field checklist, is required to allow third parties to verify that forest concessionaires or processing operations comply with the law. The development of an auditable definition of legal timber is a fundamental step required to distinguish between legal and illegal 
timber. The importance of this activity is exemplified by the fact the European Commission is seeking to stop imports of illegal timber and will introduce a regulation aimed at facilitating the import into the Union of legal timber. Implementation of the regulation, however, is possible only if legal timber can be clearly identified.

The definition of legal timber being developed by TNC and its subcontractors SGS and URS Forestry, an environmental and engineering consultant firm, includes principles of existing Indonesian law and additional social aspects. These principles relate to:

- land tenure and use rights and responsibilities,

- environmental impact,

- community relations and workers rights,

- timber harvesting laws and regulations,

- forest taxes,

- log identification transfer and delivery, and

- timber processing, sales, and shipping.

Strictly speaking, it is therefore a definition that goes beyond pure legality. This approach presents an important opportunity as well as a significant challenge.

In Indonesia, several NGOs oppose the application of existing national legislation to develop a definition of legality of timber because the existing legislation does not recognize the rights of customary owners. This opposition is clearly exemplified by a review concerning the implementation of FSC certification. The review noted that:

Free and informed consent is a central principle for FSC. Effective exercise of this right is a key safeguard that communities and indigenous people need to ensure that certified logging and plantation schemes do not violate their rights. Moreover, since in Indonesia legislative protections of land rights and customary rights are weak, absent or insufficiently enforced, then free and informed consent becomes the central safeguard for these communities. (Colchester et al. 2003, p. 9)

The review went on to conclude that a national dialogue was needed to decide whether and how to promote voluntary certification in Indonesia using international standards. It concluded that until such dialogue occurred and national consensus was achieved, FSC certification in Indonesia should be suspended.

The approach adopted by TNC to include additional social aspects in the definition of legal timber is a good opportunity to further the abovementioned national dialogue on certification. Indeed, it is likely that several national NGOs would not accept a definition of legal timber that excluded social aspects. The challenge is to develop a legal definition that includes social aspects and is acceptable to both NGOs and a large group of forest concessionaires.

With regard to chain of custody, TNC aims to deliver an innovative, costeffective, and efficient system. It will be based on data management and tracking technology to make the process more efficient, accurate, and transparent for auditors. Existing less reliable paper-based systems will not be used. A simple software package to store and retrieve data will be developed. It will manage data on forest inventory, log production, sales, and delivery information. It will comply with government reporting needs. 


\section{Do the assumptions hold?}

Producers can achieve certifiable standard of forest management in Indonesia.

Only one forest company is certified in Indonesia. Two other operations had their certificates suspended because of failure to maintain compliance with certification standards. Another two HPHs are close to certification in East Kalimantan. This shows that Indonesian producers can achieve certifiable standard of forest management, although the fact that only one concession has retained its certificate suggests that certification is difficult to maintain. Some producers note that progress towards certification is slow because of the high costs of certification, low (or nonexistent) green premiums, and an unpredictable forestry business environment in Indonesia. The major factor holding back widespread certification, however, is the lack of significant markets for certified products.

Producers that put effort into getting certified will receive commercial benefits above what they would from business as usual.

This scenario may hold true for a small number of companies, but it is yet unclear whether it applies to a significant group of producers. The Chinese and J apanese markets receive the largest share of Indonesian timber products and do not require certification. Some Japanese paper companies, ${ }^{24}$ however, are showing interest in certified products and so do some end-destinations for China's re-exports, which were equivalent to 35 million cubic metres of round-wood equivalent of timber in 2003. Financial incentives (green premiums) are rather limited. This situation may somewhat discourage large log producers and processing companies, but it is not their major problem as they are far more interested in administrative changes that would improve the business environment and reduce transaction costs. Medium and small operators are interested in green premiums to a much greater extent than large companies. In addition to the general lack of such premiums, the main problem smaller timber companies face is the high costs of certification and gaining access to the legal international market.

Affordable and realistic mechanisms can be established to differentiate between products from legal and illegal logging.

Most forest concessionaires and processing operations are familiar with the existing log administration system. The problem is that it is not enforced. The new system being developed by TNC will provide a further mechanism to be used by third parties to certify the legality of timber, as long as a broad range of stakeholders accepts it. On the basis of previous experiences, there is no reason to doubt that it is possible to differentiate legal from illegal products. The cost effectiveness of the system is being tested and it is too early to comment on this aspect. Once the cost implications of the system are assessed, a comparison of its costs and green premiums available to operators will be required to assess if the system can be considered 'affordable'.

\section{Learning with Partners}

The Alliance aims to broaden constituencies in Indonesia and increase awareness and trust among customers in key markets of the processes, mechanisms, and 
tools it develops to promote responsible forest management. This objective is to be achieved through the dissemination of information on the activities and achievements of the Alliance, including the lessons it learns.

The impact of this component should start to become evident in the second and third years of the Alliance's work. For the first year of activities, it is useful to consider the views of some key stakeholders. Their interests and concerns will affect the uptake of the Alliance's recommendations and new systems for certification and conservation of forests.

Stakeholders' views concerning the specific activities of the Alliance were reported in the preceding sections. Here we report on issues of general concern to stakeholders. Many stakeholders were consulted. The complete list is presented in Annex III.

\section{Rural people, civil society, and the private sector}

Rural people often participate in illegal logging activities and benefit from them (Obidzinski 2003). There are situations in which rural people benefit from illegal logging activities which may be regarded by society as harmful to the environment and, as a result, to other people. Often, however, they do not have any alternative livelihood options. Other times, biased laws criminalise legitimate rural livelihood activities. For example, rural people are forced to live as 'squatters' because the forest is state property. The reduction of illegal logging could in some situations negatively affect livelihoods. The interest of rural stakeholders in supporting the mechanisms and processes developed by the Alliance should not be taken as a given.

NGOs stress the risk that certification will simply allow companies that have exploited the forest and the local people to continue doing business as usual. Local NGOs would like to receive more information about the work carried out by the Alliance so that they can better understand its implications. The concern voiced by NGOs about the shipment of timber to the USA organized by the Tropical Forest Foundation as part of its work in West Kalimantan (see Box 5) exemplifies the need to engage a range of NGOs in the debate over verification of legality and certification through the communication program of the Alliance, as well as to carry out specific program activities.

Forest concessionaires stress that the ongoing debate between central and regional governments over the allocation of authority and responsibilities regarding forest management results in a rather uncertain business environment. This climate may affect their interest in investing in certification accreditation.

The forestry industry notes the uncertainties arising from existing land use allocation processes and land tenure and forest resources disputes. There are cases in which government institutions have awarded resource exploitation licenses overlapping with pre-existing licenses. This includes mining licenses overlapping with forest concession areas ${ }^{25}$ and small-scale forest concessions overlapping with large concession areas (HPHs). With regard to land tenure and forest resources disputes, they note that land tenure claims on forest concessions can stall the certification of an area.

Forest concessionaires and processing companies see certification as an opportunity to maintain or increase market share, as certification improves the 
Box 5. Log tracking systems

- $\quad$ PT Diamond Raya holds a CoC certificate issued by SGS Qualifor as part of the forest certification procedure linking the certified forest with manufacturers, retailers, and consumers. The management of PT Diamond Raya reports no significant difficulties in establishing and maintaining the $\mathrm{CoC}$. It also reports that since the company has established the $\mathrm{CoC}$ system the number of monitoring visits by forestry officials has decreased.

- $\quad$ The Tropical Forest Foundation works with PT Suka Jaya Makmur in West Kalimantan on the implementation of reduced-impact logging. The initiative includes the establishment of market links with the United States of America (e.g., Home Depot). A log tracking system provides assurance that the timber is produced legally and by use of reduced impact logging methods. Currently, PT SJ M is being evaluated as prospective member of PFTN (Nusa Hijau).

public image of the company. Unless markets require legally verified or certified products, companies have little incentive to get their products certified.

\section{Government institutions}

District governments would like to resolve the uncertainty over the allocation of authority over forest management and the distribution of responsibilities. They would like to have greater authority. The uncertainty over forest management authority and responsibilities is an issue that goes beyond the scope of work of the Alliance, but it will affect the uptake of its recommendations and innovations.

District governments' capacity to deal with forest management issues varies. Some administrations appear to have good capacity and understanding of the issues. Others are less aware of forest management issues, including the potential benefits derived from forest conservation. Increased availability of information on the implications of verification of legality and certification and the conservation of HCVFs would benefit their decision-making processes.

The central government has adopted several laws, decrees, and regulations related to sustainable forest management. They have not been implemented, however, as demonstrated by the lack of significant forest areas managed according to sustainable forest management (SFM) criteria. Understanding of technical issues relating to SFM seems to be high among forestry officials. Improved access to information on SFM, including verification of legality and certification, may not be the most significant factor in bringing about SFM. Increased co-ordination among government institutions may be required. This may include greater co-ordination with the Ministry of Finance (e.g., to monitor financial operations) and with the Ministry of Industry and Trade to improve regulation of processing operations (e.g. , issuing of licenses for processing operations) and to enhance the business environment so as to stimulate investment in SFM. 


\section{Do the assumptions hold?}

Maintaining open and transparent communications with the stakeholders will give credibility to the mechanisms and processes developed.

Maintaining open and transparent communications with stakeholders is a must for a program engaged in a politically sensitive issue such as illegal logging in order to minimize potential risks arising from misunderstandings concerning the scope of the program. However, the interests of stakeholders are important determinants of whether the mechanisms and processes developed by the Alliance are deemed credible. The previous sections and Part 1 of the report highlight the complex nature of illegal logging. Many stakeholders effect the causes and are affected by illegal logging. Whether they benefit or suffer from illegal logging will determine their interest in supporting the credibility of the mechanisms and processes developed by the Alliance or in discrediting and ignoring them.

National or international campaign groups can be persuaded to recognize the complementary role of other civil society groups that pursue solutions-based engagement with the private sector and not undermine those efforts.

Civil society groups had rather mixed reactions to the shipment of timber (harvested with reduced impact logging methods) to the USA under facilitation of the Tropical Forest Foundation. Some NGOs also have relatively negative views concerning the preconditions for FSC certification in Indonesia. This exemplifies the complex but important task of maintaining open dialogue with other civil society groups. Whether they can be 'persuaded' of the necessity to implement the solutions-based engagement with the private sector will be determined to a significant extent by their capacity, and that of their constituencies, to understand both the benefits and the risks involved in the approach adopted by the Alliance. 


\section{Part 3. \\ Summary of Findings and Recommendations}

\section{Learning Lessons and Adapting}

This part of the report serves as a summary of the findings detailed in Parts 1 and 2. Recommendations are also presented and these are highlighted throughout the text. The authors of this report would like to stress that these recommendations are somewhat tentative given the early stage of implementation of the Alliance's activities. We expect stronger and more detailed conclusions and recommendations to materialise as the Alliance proceeds.

\section{Achievements during the first year: was the Alliance successful?}

\section{Strengthening market signals}

The Alliance has progressed well in some significant areas in its first year. Alliance staff have contributed to international and national policy debates on illegal logging, which could help strengthen market signals. WWF and TNC have maintained extensive contacts with organisations in China such as the Certification and Accreditation Committee and the National Forest Administration. In J apan the partners have built strong relationships with the Ministry of Foreign Affairs and the Forestry Agency, particularly through involvement in the Asia Forests Partnership. These government institutions have expressed interest and intention to explore options for closer co-operation with the Alliance. Strong links, collaboration and information sharing with European and North American policymakers have also been established, especially with the United Kingdom and the European Commission. It is difficult to determine the impact of these activities given that policy changes normally take place over extended periods, but it is a significant aspect of the work of the Alliance in attempting to bring about a shift in public and private timber procurement policies.

At the private sector level, WWF's FTN in J apan and China show good progress having reached 26 members in J apan and 10 members in China against initial targets of 30 and 10 members, respectively. Notably, a major Japanese paper importer, Ricoh, is seeking to ensure that its imports from Riau come from legally harvested timber. Ricoh was among five major paper importing companies from J apan that visited Riau to gain firsthand experience of APP and APRIL pulp and paper operations. 
It seems that this experience of visiting Sumatra was an important factor contributing to Ricoh's decision; it may be an important lesson about how to bring about change in the behaviour of companies. The Alliance should then consider significant expansion of field visits by Asian wood buyers.

WWF and APP have signed a letter of intent. The two organizations committed to collaborate to explore options for the protection of HCVF (see below) and to implement a log tracking system in order to verify the legality of the timber used by APP.

TNC has built and maintained strong engagement with US companies, including The Home Depot, Lowe's, Georgia Pacific, and Boise Cascade. These companies have sought advice from TNC as they developed revised wood buying policies that eliminate wood of illegal or suspicious origin from Indonesia.

\section{Increasing certified wood supply}

The Alliance has also made progress in increasing the future supply of certified Indonesian wood products. Several prospective members of the Indonesia FTN are being evaluated with baseline appraisals and action plans and being prepared to improve their management. The first year target called for five companies and five community group members of the FTN.

In East Kalimantan, TNC has established formal agreement with a large integrated forest products company, Sumalindo Lestari J aya, and made good progress with others, involving providing technical support to improve forest management. Sumalindo has now completed audits for FSC certification.

\section{Developing practical tools to reduce illegal logging}

TNC has completed the definition of legality of timber, guidance notes for auditors, and the design of a log tracking system. These are important milestones toward building capacity to address illegal logging and constitute the first such attempt, as far as we are aware. It is an important contribution in itself. Outcomes of the debate to be generated by the document, and its possible adoption, will deserve further attention. Development of the log tracking system is also progressing and whether, why, and how it will be adopted will need to be considered. Significant obstacles related to cost, technology, and industry interest remain.

\section{High conservation value forest}

The Alliance has made important, quantifiable contributions to the maintenance of HCVF. As of late 2003 this effort included the following:

- In Riau, 58,500 ha of HCVF have been identified in the Arara Abadi timber plantation concession of APP, and Riau Andalan Pulp and Paper is discussing with WWF setting up arrangements to protect 150,000 ha of HCVF in Tesso Nilo.

- In East Kalimantan, PT Sumalindo Lestari J aya has identified 50,000 ha of HCVF within its forest concession. The company proposed in its application for certification that this area be conserved. TNC and the Berau District government have identified 12,000 ha of HCVF in state forest land in the Lesan area. TNC also identified about 20,000 ha in the forest concession of PT Gunung Gajah Abadi, and negotiation to establish the area is ongoing. 
A total of about 300,500 ha were identified against a target of 400,000 ha for year one. Given the complex situation in Indonesia, this is excellent progress. There has also been good progress in development of an HCVF toolkit for use by forest products companies across the country, in collaboration with the Alliance partner ProForest.

\section{Obstacles to progress of the Alliance}

China and Japan have developed agreements with Indonesia to support the latter in reducing illegal logging. The stated political will, however, has yet to translate into concrete measures to restrict trade in illegally harvested logs and their products. Government procurement guidelines for sourcing legally verified or certified timber have yet to be considered in China and J apan, although Hong Kong appears to have started on this path. As a result, there has been no increase in the import of verified and certified timber products into J apan and China from Indonesia, against the year one targets of 10 percent of all J apanese imports from Indonesia and 5 percent for China. These targets were too ambitious. The Alliance should consider adjusting some of its targets to achievable levels.

Production of verified and certified timber products in Indonesia will increase if there is sufficient demand. The size of such demand is not clear. It is clear, however, that demand for certified forest products from Indonesia outstrips supply. Nevertheless, financial incentives for production and use of illegal timber remain high. An improved understanding of the potential benefits of producing legal timber, and how to increase the incentives to do so, is therefore needed to develop policies to stimulate legal production. The Alliance should focus greater attention to improving incentives for production of verified legal or certified wood products.

Consensus on the definition of HCVF is slowly expanding among civil society and business, but the concept does not yet guide the process of selecting the location of new forestry and oil palm plantations. Regulations are needed to incorporate the concept of HCVF into regional spatial planning. A challenge to the establishment of HCVF in existing forest concessions is the availability of land for the establishment of plantations in alternative areas. In addition, the financial costs incurred by forestry companies as a result of reduced timber harvest from the HCVF area presents a significant challenge to the establishment of HCVFs. The Alliance should give greater attention to policy changes that would provide incentives to companies to set aside or reduce wood extraction from forests of high conservation value.

\section{How well is the Alliance moving towards its goal?}

The goal of the Alliance is to bring about environmentally appropriate, socially beneficial, and economically viable use of production forests and to mitigate threats to high conservation value forests in Indonesia. Good progress towards this goal has been made in the first year, as noted above. Yet, the quantitative indicators for benchmarking the success of the program are too ambitious. According to the indicators, at the end of the third year of activities the program is expected to have achieved the following:

1. GFTN members in China and J apan will account for 15 percent and 30 percent, respectively, of timber imports from Indonesia. 
2. Third party verified legal timber will amount to 30 percent of the total volume of timber exported from Indonesia.

3. Third party certified timber will be 10 percent of the total volume of timber exported.

4. Four hundred thousand hectares of forest will be managed as HCVF, and 1 million ha will be in the process of being zoned.

These targets are unrealistic. The Alliance needs to revisit these targets.

Beyond quantitative indicators, the Alliance would achieve significant success if it had a definition of legality of timber adopted by the government and accepted by civil society and third party verification organizations. The impact of this achievement would be difficult to measure but it is nonetheless important given that it is a requirement for the development of a market for legally verified timber. The Alliance is making strong progress in this area. It is advisable to consider the broad acceptance of a definition of legality as one of the major contributions of the program and to allocate sufficient resources to this activity.

An important factor influencing the achievement of the goal of the Alliance is the transformation of political will into practical measures to reduce production of and trade in illegally sourced wood products from Indonesia. This objective entails introducing trade measures and government procurement policies to stimulate trade in legal timber products. This strategy is at the root of the most important assumption underlying the Alliance's work: market incentives will motivate producers to improve forest management practices that will result in forests managed to certifiable standards.

The incentives for such market transformation continue to be limited and it is far from certain that they can achieve the level needed to generate widespread change in corporate practice. Government policies on public and private procurement of timber in China and J apan can be expected to take into account their impacts on government budgets as well as on the private sector. Advocacy can be expected to work if it has the substantive arguments to convince the governments. A detailed assessment of the incentives required to encourage companies to change their practices and how existing ones can be improved is needed and should be a priority for the Alliance.

\section{Learning and adapting}

Indonesian society's preferences in regard to forest management and conservation are not well known, as noted in the section on causes of illegal logging. Yet they contribute to the formation of government policies and will gain importance as democratization and decentralisation expand. They are important because if logging (legal or illegal) is regarded as beneficial to local communities, it is unlikely that strong support for anti-(il)legal logging campaigns will be effective. Social views will also affect the adoption of the concept of HCVFs and stepwise certification. The Alliance should develop a stronger understanding of people's views of logging, as well as the benefits and costs associated with changes in policy.

The number of large forest concessions is declining. They are being replaced by small concessions and by illegal logging activities. A change in the structure of forest concessions affects their financial viability and, hence, the market incentive structure required to produce legal timber. It also affects the viability of certification 
schemes. The Alliance should complete further analysis of the implications of this decline in large logging concessions.

\section{Learning and adapting to expand verified and certified timber demand and supply}

The extent of market demand for legal versus illegal timber products is unclear, though strong signals are now coming from buyers and some governments in Europe and North America, and beginning in J apan. The Alliance should develop estimates of price premiums for legal timber products that would represent an incentive for producers, if the market was found to be substantial.

District and provincial governments and NGOs need to be fully involved in certification-related activities. Government authorities should participate so that, it is hoped, they will gain better understanding of certification and will become more supportive of its implementation. NGOs, on the other hand, need to be continuously engaged in the dialogue regarding the stepwise approach to certification in order to narrow the current differences of opinion on this subject within Indonesia. The Alliance should devote more resources and skilled staff to outreach activities and partnership with national and local government agencies as well as with local NGOs and civil society leaders. The NGO small grants component of the Alliance should be implemented with urgency.

\section{Learning and adapting to improve financial tools and encourage their uptake}

Availability of more information about forest issues in Indonesia could build both the awareness and concern of financial institutions that are involved in servicing the forest products industry. Information about the environmental performance of forestry firms (e.g., percentage of timber sourced from legal sources) would provide valuable data to financial institutions for the assessment of risks they may incur in funding forestry operations. Information made public in the form of a database linking financial institutions and the forestry firms to which they lend would increase the image risk for financial institutions and stimulate the adoption and implementation of appropriate lending guidelines.

A relatively significant amount of credit appears to be provided by institutions from countries with weak environmental constituencies to forest-related projects. The Alliance should consider establishing a dialogue with relevant financial institutions in Asian countries, particularly in China and Malaysia, and assessing their interest in developing environmental screening tools.

A potential area of work to be considered by the Alliance is the monitoring of ECAs. ${ }^{26}$ Involvement of the Alliance in this area could strengthen the existing NGO campaign. Specifically, the Alliance should consider monitoring large-scale forestry investments in Indonesia and the role of ECAs in funding them, given that a large-scale project can affect hundreds of thousands of hectares of forest.

The implementation of money-laundering legislation is one way to create a financial disincentive for illegal logging, although it is likely that money-laundering legislation could be used effectively only in relation to the operations of large companies. The Alliance may wish to assess whether supporting the implementation of money-laundering legislation would strengthen the incentives for large companies to use legal timber. 


\section{Learning and adapting to conserve HCVFs}

Stakeholders' awareness about the HCVF concept is generally low. The limited knowledge about the concept is compounded by stakeholder-specific interpretations of the definition of HCVFs and associated forest management requirements and practices.

Forest concessionaires tend to see HCVF as a new name for an old practice. The law has long required that they set aside portions of their concessions for conservation purposes, though they have often not done so. They claim they have long been protecting environmentally sensitive areas in their concessions and they say these areas are HCVF. The Alliance should seek to instil a comprehensive understanding of HCVF among forest concessionaires. An information/training needs assessment should be carried out to find the most appropriate ways to increase knowledge about HCVF.

The tendency to equate HCVF with effective standard conservation practices is also evident among pulp and paper producers and their plantation managers. They all claim to have been implementing HCVF in plantation areas for years. Pulp and paper companies in Riau appear to co-operate on a more comprehensive adoption of HCVF practices, as evidenced by the letter of intent between APP and WWF that resulted in the creation of over 60,000 ha of HCVF. In return, WWF agreed to facilitate a land swap of equal size for APP. Given legal, administrative, and social complications, the companies doubt that land swaps of this kind can be effectively arranged. In addition, given that FSC certification is unachievable because plantations are in areas cleared after 1994, pulp and paper producers in Riau and elsewhere are considering other types of certification, such as the modular approach developed by ProForest. Even though non-FSC certification schemes have less clout, the pulp and paper companies consider them useful nevertheless. The Alliance should maintain the current engagement with the pulp and paper industry by assisting in finding practical ways to implement land swaps to sustain the sector's interest and co-operation on the HCVF issue.

Among those who know least about HCVF are district and provincial government agencies and NGOs. The lack of understanding of this issue results in unnecessarily suspicious responses. Many government officials (whether at district or provincial level) feel somewhat excluded or bypassed by Alliance activities pertaining to HCVF. (A notable exception is TNC's close partnership with the Berau district government.) The Alliance must ensure that these feelings of exclusion by local governments, which are a potential source of conflict, are minimized through engagement and co-operation with government institutions.

The same is the case with Indonesian activist NGOs. As most are against industrial logging, plantations, and pulp and paper operations, it is important to explain and demonstrate that HCVF initiatives do not compromise social justice and equity issues. The Alliance must expand its effort to engage local NGOs in its activities and support them with small grants and technical input.

\section{Learning and adapting to facilitate verification of legal wood and timber tracking in Indonesia}

The legal framework regulating forest management lacks broad social acceptance in Indonesia, and central and district governments contest institutional authority over 
forest management. These challenges to the development of a definition of legal timber are significant. No matter how big the challenge, however, such a definition and its implementation are urgently needed to enable forest concessionaires and timber-processing operations to access markets requiring proof of legality.

NGOs' scepticism of certification has been noted above. This scepticism will have to be taken into account in the process of developing a definition of legality. This process needs to be transparent and must allow the participation of NGOs and other stakeholders. The Alliance has made good progress in this process. Their participation in the process does not, however, guarantee that a broadly accepted agreement on the definition of legal timber can be reached.

Forest products companies that hold FSC CoC certificates prove that this is technically and institutionally viable in Indonesia. The key question is whether timber tracking will become a practice adopted by a significant number of forestry businesses. The size of the market for verified legal timber and the revenues that can be generated by accessing that market are key factors in determining the uptake of log tracking to produce and market legal timber. The financial viability of the CoC system being tested by TNC and its partners in East Kalimantan will have to be assessed by considering the revenues generated through the sale of verified legal timber and the costs associated with the CoC system.

Finally, it should be noted that WWF has signed letters of intent with APP and PT Diamond Raya Timber (which already holds FSC CoC certification) to strengthen the chain of custody system and ensure the legality of timber supplies. The experience gained through the pilot testing of the system in East Kalimantan should be compared with that of APP and PT Diamond Raya Timber to assess the applicability of the system to a range of timber producers and processing operations.

\section{Learning and adapting with partners}

Illegal logging is a complex problem. Many stakeholders are concerned, involved, and affected, and it can be a very profitable activity with links to Indonesian senior officials and the military. Several causes are at the roots of illegal logging. The Alliance intends to develop practical solutions to the problem of illegal logging. The interests of stakeholders will influence the uptake of these solutions.

A detailed stakeholder analysis would benefit the process of developing solutions, facilitate their uptake, and assist in targeting the dissemination of lessons learnt by the Alliance. A broad, informal understanding of the stakeholders involved in illegal logging is developing in Indonesia.

Stakeholder interests have to be better understood and taken into account in developing specific policies and technical options to combat illegal logging. The Alliance should consider the implications for its activities of the stakeholders and illegal logging analysis to be carried out by the WWF/World Bank Alliance. 


\section{Endnotes}

${ }^{1}$ Different sources cite different figures related to revenue losses. The figure reported here is, to our knowledge, the best documented one. Further research needs to be done to assess this aspect of illegal logging.

2 Upik Djalins, Anwar, Kath Shurcliff 2003. Monitoring and evaluation of impact: a proposed framework to USAID. Alliance draft report.

3 These are preliminary estimates only. Inconsistencies in official records need to be taken into account. For instance, in 2001 about US\$264,871,264 were collected in Reforestation Fund fees (Sarsito presentation). At the maximum rate of US $\$ 16$ per cubic metre, this revenue implies a harvest of about $16,554,454$ cubic metres, which is some $60 \%$ above the official harvest reported in Table 1. Obviously, this latter figure implies a lower level of illegal harvest, which however would still be substantial. The potential loss in Reforestation Fund fees was US\$533, 511, 400 in 2001.

${ }^{4}$ This assumption is based on the following: (i) stocking rates in undisturbed forest in Sumatra and Kalimantan are, respectively, 36.1 and $54.5 \mathrm{~m}^{3} /$ ha (class $>50$ $\mathrm{cm} \mathrm{dbh);} \mathrm{and} \mathrm{(ii)} \mathrm{illegal} \mathrm{logging} \mathrm{normally} \mathrm{takes} \mathrm{place} \mathrm{in} \mathrm{secondary,} \mathrm{degraded} \mathrm{forest}$ and at intensities lower than conventional logging operations.

5http:// www.transparency.org/cpi/2003/ cpi2003. en.html. Accessed November 2003.

${ }^{6}$ PP No. 6 1999, SK Menhutbun No. 310/ Kpts-II/ 1999 and SK Menhutbun No. 317/ KPTS II/ 1999.

${ }^{7}$ Forest Law Enforcement and Governance East Asia Ministerial Conference, Bali, Indonesia, 11-13 September 2001; Ministerial Declaration, p. 1. See: Inweb18. worldbank. org/ ESSD/ essdext. nsf/ 14ByDocName/ Forest Governance ProgramMinisterialProcesses.

${ }^{8}$ Ibid., p. 2.

9 Thanks to Chen Hin Keong, Senior Forest Trade Advisor, TRAFFIC, for providing this information.

10 http:/ / www. whitehouse.gov/ infocus/ illegal-logging/ piail.html.

${ }^{11}$ Derived from the project design document submitted by the Alliance to USAID.

12 These factors are indicative and not contractually binding quantities, given that they were included in the project proposal but not in the contract awarding the funds (Nigel Sizer personal communication). 
13 SK No. 58/ Kpts/ KWL4.1/ 2000.

${ }^{14}$ Ministry of Forestry decree no. 168/ Kpts-IV/ 2001, Utilization \& Distribution of Ramin (Gonystylus spp).

${ }^{15}$ For the time being we assume that a system is in place and implemented to prove the company's involvement in illegal logging and trade as well as to screen companies and deny services.

${ }^{16}$ The Equator Principles is a set of voluntary guidelines developed by banks for managing social and environmental issues related to the financing of development projects. For the text of the principles and the adopting banks see http:// www. equator-principles.com

${ }_{17}$ See Wakker and van Gelder (2003) for a description of how this applies to oil palm development in Indonesia.

18 The company would probably rank these options with regard to their profitability and viability.

${ }^{19}$ This hypothesis assumes financial viability of legal operations and availability of timber to make it possible.

20 David Brown, DFID, personal communication.

${ }^{21}$ I.e., the 15 member states before the expansion of the EU in 2004.

${ }^{22}$ Ministry of Forestry decree no.126/ Kpts-II/2003. Forest Product Administration.

${ }^{23}$ See www. forestandtradeasia.org for a list of companies holding CoC certificate by 15 July 2003.

${ }^{24}$ An example is Mitsubishi Paper Mills, a member of the J apanese buyer group of FTN.

${ }^{25}$ An example is the case of PT Berau Coal Mining and PT Hutan Sanggam Labanan, formerly PT Inhutani I.

${ }^{26}$ ECAs from countries such as Canada, Denmark, Finland, Germany, Japan, Spain and Sweden have been active in forestry-related projects in Indonesia (Fried and Soentoro 2000). 


\section{References}

Ascher, W. 1999 Why governments waste natural resources: policy failures in developing countries. The J ohns Hopkins University Press, Baltimore.

Asia Pulse 2003 Export ban does little to stop log exports from Indonesia. 20 October.

Barr, C. 2001 Banking on sustainability: structural adjustment and forestry reform in post-Suharto Indonesia. Macroeconomics for Sustainable Development Program Office, WWF, and CIFOR, Washington, DC, and Bogor.

Bisnis Indonesia 2003a Pengurangan J atah Tebangan Tingkatkan Kayu Ilegal. 22 May.

Bisnis Indonesia 2003b Mengendalikan illegal logging Melalui Perbankan. $4 \mathrm{~J}$ uly.

Bisnis Indonesia 2003c APHI: Tindak Tegas Eksportir Log. 22 October.

Bisnis Indonesia 2003d Pengusaha HPH Minta Ekspor Log Dilonggarkan. 22 October.

Bisnis Indonesia 2003e Tinjau Ulang Kebijakan Ekspor Log. 23 October.

Casson, A. 2001 Decentralisation of policies affecting forests and estate crops in Kotawaringin Timur District, Central Kalimantan. Center for International Forestry Research, Bogor.

Casson, A. and Obidzinski, K. 2002 From new order to regional autonomy: shifting dynamics of illegal logging in Kalimantan, Indonesia. World Development 30(12):2133-2151.

Colchester, M., Sirait, M. and Wijardjo, B. 2003 Implementation of FSC principles nos. 2 and 3 in Indonesia: obstacles and possibilities. AMAN, WALHI, Rainforest Foundation, Jakarta.

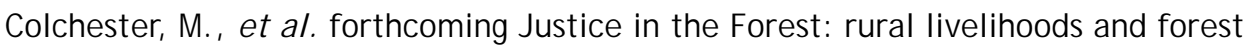
law enforcement. CIFOR Occasional Paper. CIFOR, Bogor.

Conservation and Community Investment Forum (CCIF) 2002 Analysis of the status of current certification schemes in promoting conservation. CCIF, San Francisco.

Dykstra, D.P., Kuru, G., Taylor, R., Nussbaum, R., Magrath, W. B. and Story, J. 2002 Technologies for wood tracking: verifying and monitoring the chain of custody and legal compliance in the timber industry. Environment and Social Development East Asia and Pacific Region Discussion Paper. The World Bank.

Faisal 2003. Picture of community forest. Presentation Paper. Arupa, J ogjakarta.

Forests and European Union Resources Network (FERN) 2002 Cleaning up ECAs: the possibilities for action at the EU Level. FERN, Moreton in Marsh.

Forests and European Union Resources Network (FERN) 2004 To buy or not to buy: timber procurement policies in the EU. FERN, Moreton in Marsh. 
Forest Watch Indonesia/Global Forest Watch (FWI/GFW) 2002 The state of the forest: Indonesia. FWI/ GFW, Bogor and Washington, DC.

Fried, S. and Soentoro, T. 2000 Export credit agency finance in Indonesia. Environmental Defence; Bioforum. http:/ / www.environmentaldefense.org/ documents/631_ACF661.pdf

Hinrichs A. and Agung, F. 2001 Brief about certification working groups in Indonesia. Gesellschaft für Technische Zusammenarbeit, Eschborn, Germany.

Holmes, D. A. 2002 Indonesia: where have all the forests gone? Environment and Social Development, East Asia and Pacific Region, Discussion Paper. The World Bank, Washington.

Jakarta Post 2003 Using anti-money laundering laws to fight forestry crime in Indonesia. $15 \mathrm{~J}$ une.

Jarvie, J., Hiller, M. and Salim, A. 2002 HCVF guidelines for forest managers in Indonesia. TNC/USAID report.

Jarvie, J. and J eyaraj, K. 2002 Inception report: HCVF and Giam Siak Kecil. WWF report.

Kompas 2003a Kuota kayu Bulat Kalsel Habis. 3 J une.

Kompas 2003b Pelarangan Tak Mampu Bendung Ekspor Kayu Bulat. 6 November.

McCarthy, J.F. 2002 Turning in circles: district governance, illegal logging, and environmental decline in Sumatra, Indonesia. Society and Natural Resources 15:867-886.

Obidzinski, K. 2003 Logging in East Kalimantan, Indonesia: the historical expedience of illegality. University of Amsterdam, Amsterdam.

Palmer, C.E. 2001 The extent and causes of illegal logging: an analysis of a major cause of tropical deforestation in Indonesia. University College London and University of East Anglia, London.

Partnership for Governance Reform in Indonesia 2001 A national survey of corruption in Indonesia. Jakarta.

Patlis, J. 2003a Mapping Indonesia's forest estate from the lawyer's perspective: law, legal fictions, illegal activities and the grey area (preliminary assessment). World Bank/ WWF, J akarta.

Patlis, J.M. 2003b Holding the purse strings to illegal forestry activities: engagement with financial institutions and investigation of financial crimes. Draft. Center for International Forestry Research, Bogor.

ProForest 2003 Modular implementation and verification (MIV): a toolkit for the phased application of forest management standards and certification. ProForest, United Kingdom.

Purwo, S. 2003 Proposed HCVF program in Riau by 2004. WWF presentation.

Rametsteiner, E. 2002 Market for certified forest products. ECE/ FAO forest products annual market review 2001-2002. UNECE/ FAO, Geneva, Switzerland.

Mohd Shahwahid, H. O. 2004 Forest certification in Malaysia. Paper presented at the Symposium 'Forest Certification in Developing and Transitioning Societies: Social, Economic, and Ecological Effects', Yale University.

Smith, J., Obidzinski, K., Subarudi and Suramenggala, I. 2003 Illegal logging, collusive corruption and fragmented governments in Kalimantan, Indonesia. International Forestry Review 5(3): 293-302.

Tacconi, L. 2003 Fires in Indonesia: causes, costs and policy implications. Occasional Paper No. 38. Center for International Forestry Research, Bogor. 
Tacconi, L., Boscolo, M. and Brack, D. 2003 National and international policies to control illegal forest activities. Center for International Forestry Research, Bogor.

Tacconi, L., Obidzinski, K., Smith, J., Subarudi and Suramenggala, I. forthcoming Can legalization of illegal forest activities reduce illegal logging? Lessons from East Kalimantan. J ournal of Sustainable Forestry.

URS Forestry 2002 Review of formal and informal costs and revenues related to timber harvesting, transporting and trading in Indonesia. Draft. The World Bank, J akarta.

Wakker, E. and van Gelder, J.W. 2003 Risking the forests: identification and management of Indonesian oil palm plantation risks by financial institutions. Draft report prepared for WWF. 


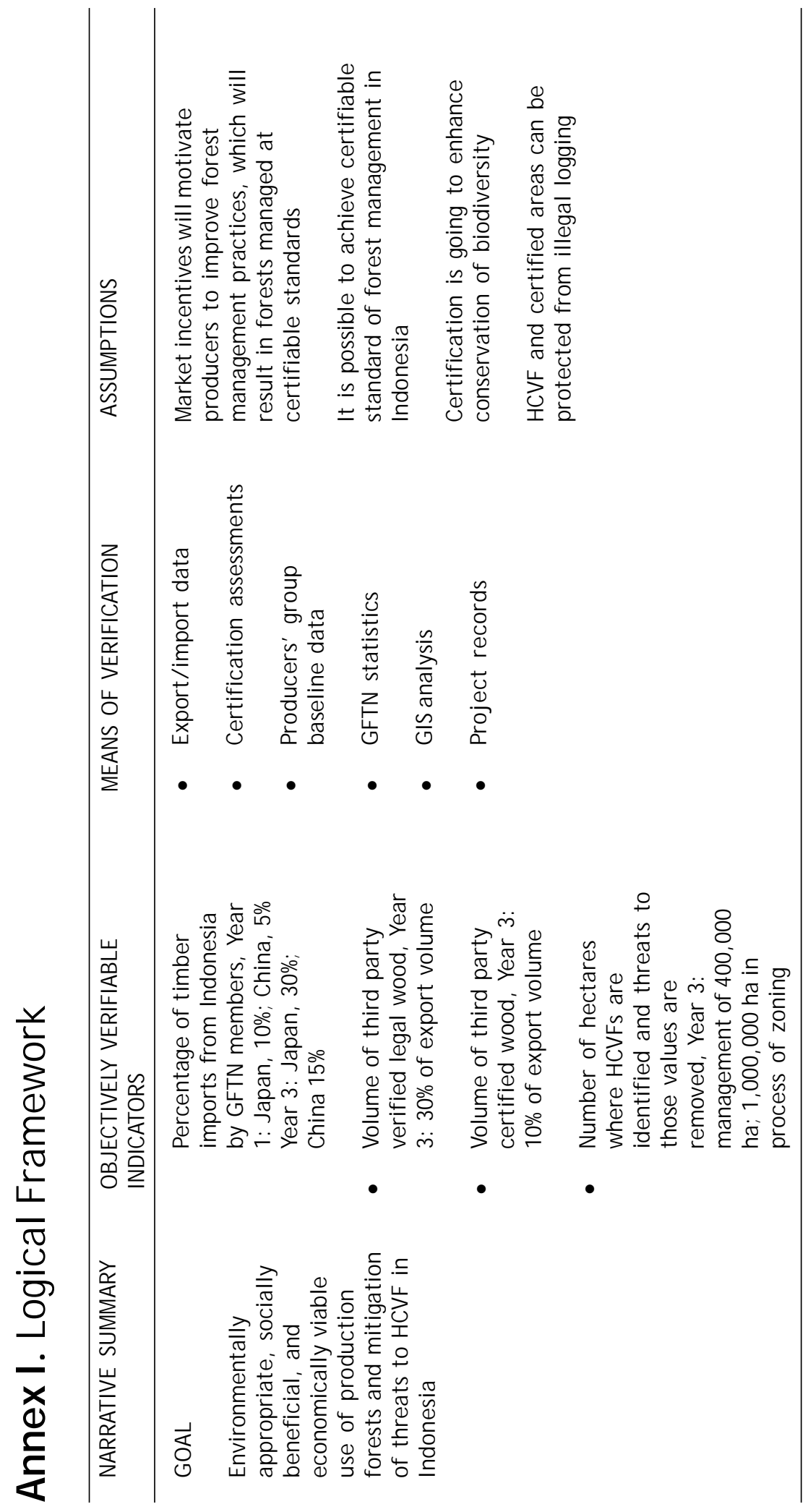




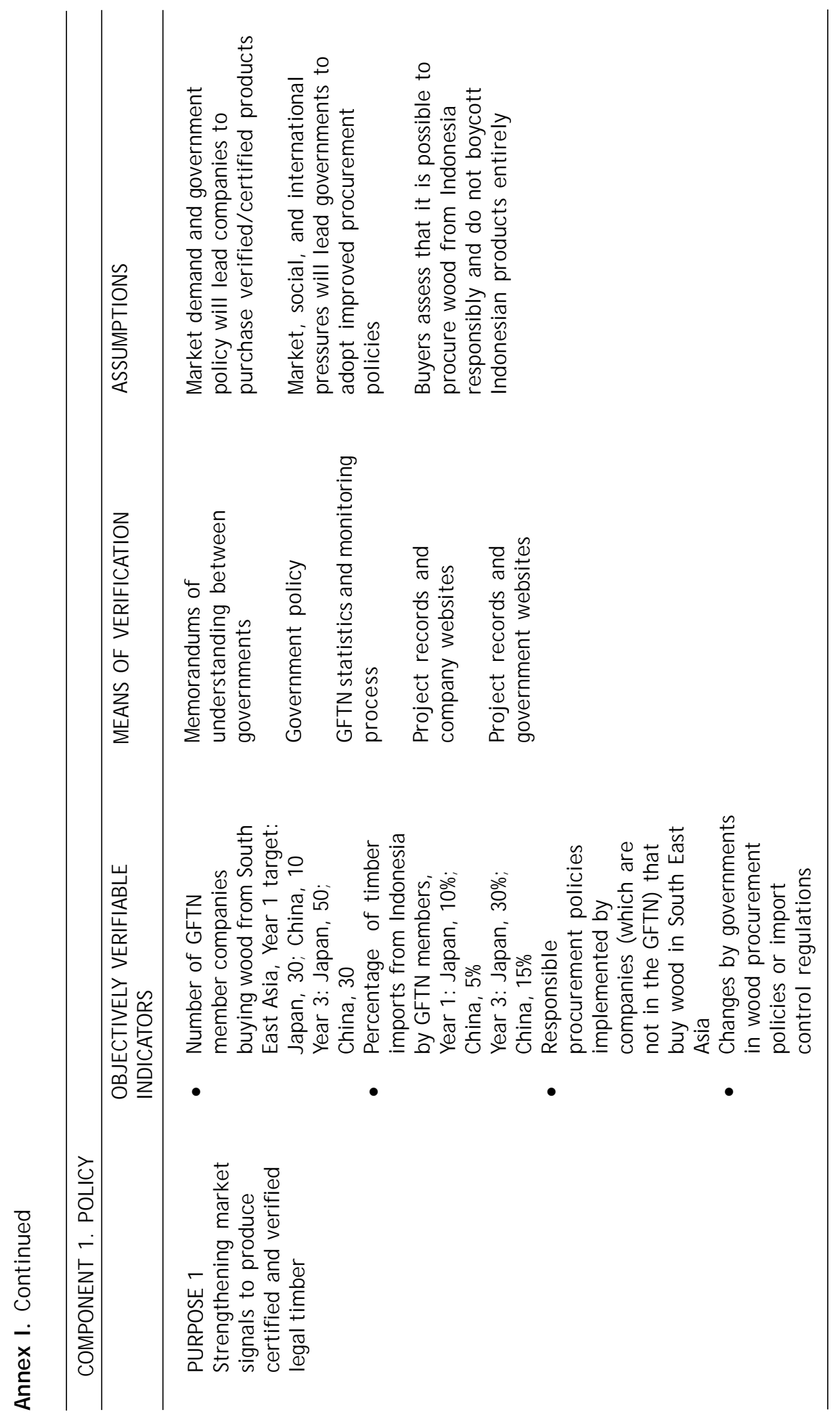




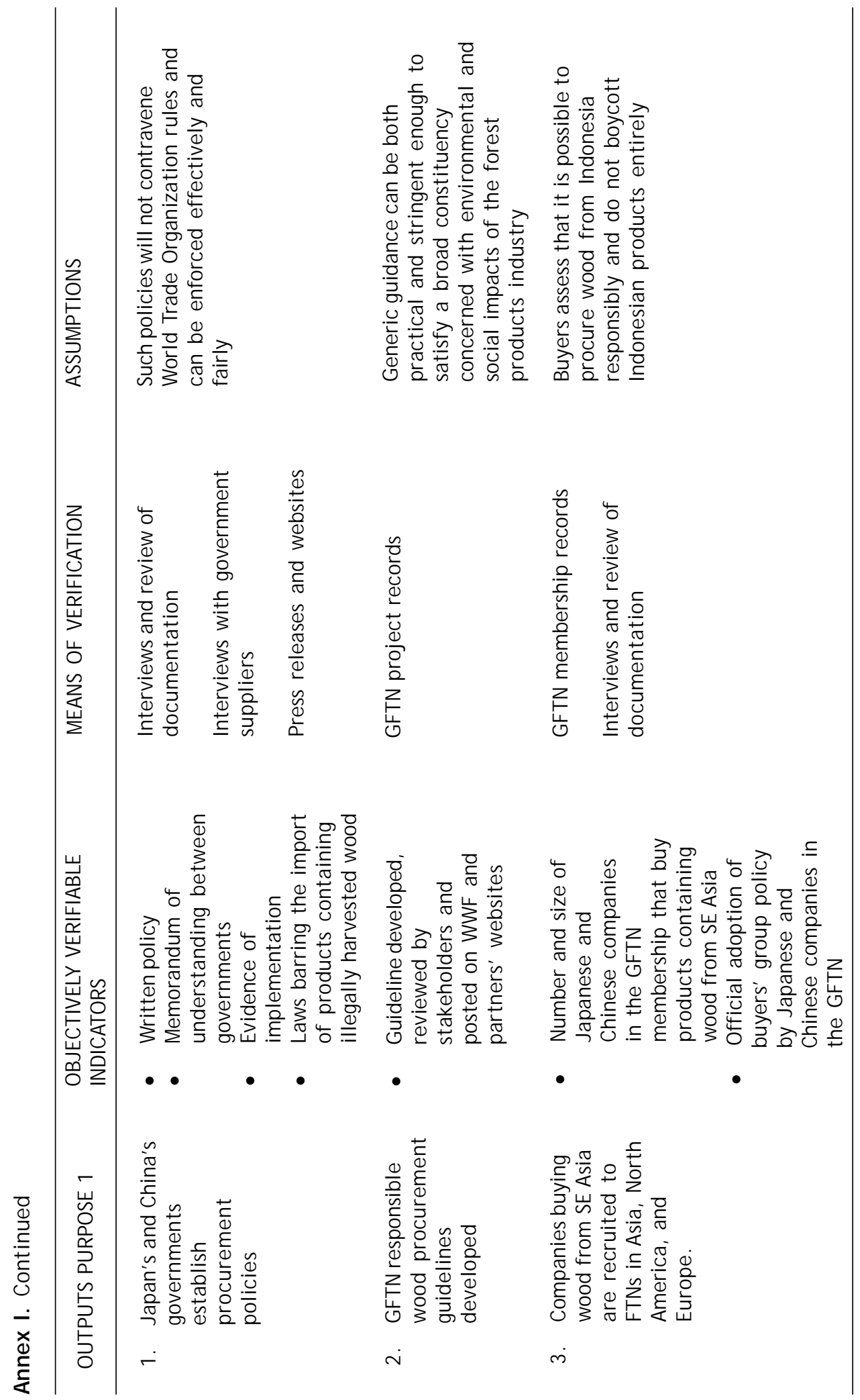




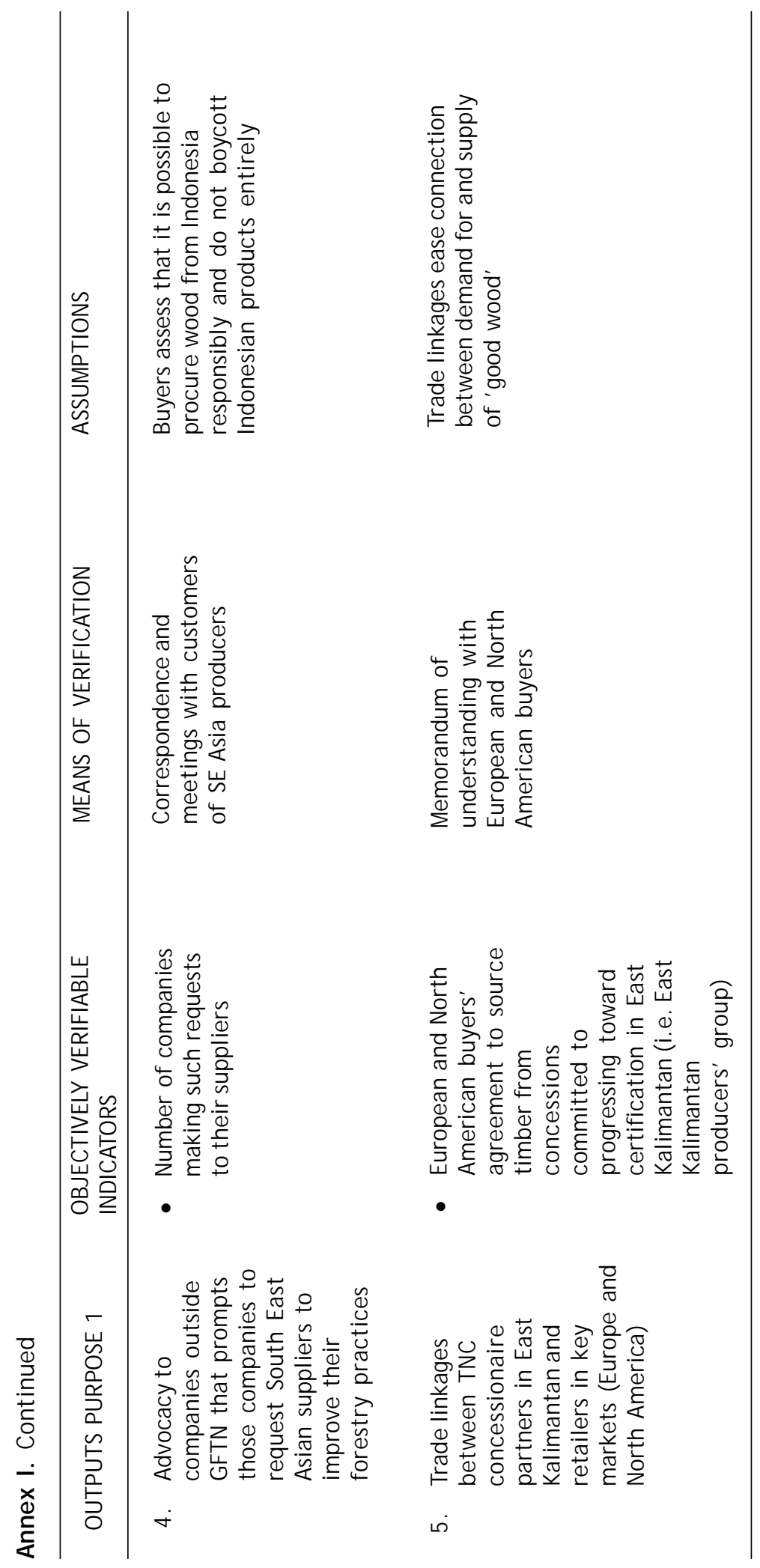




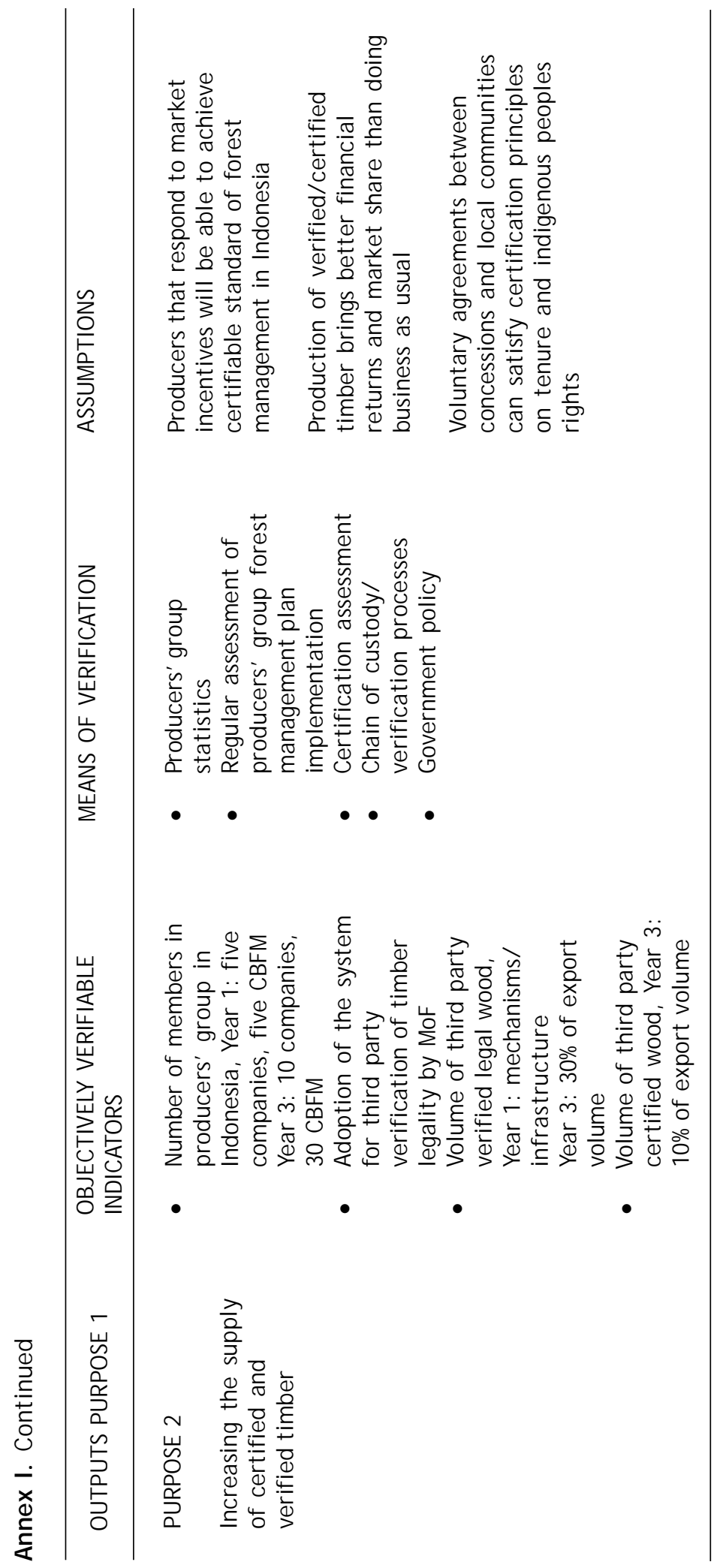




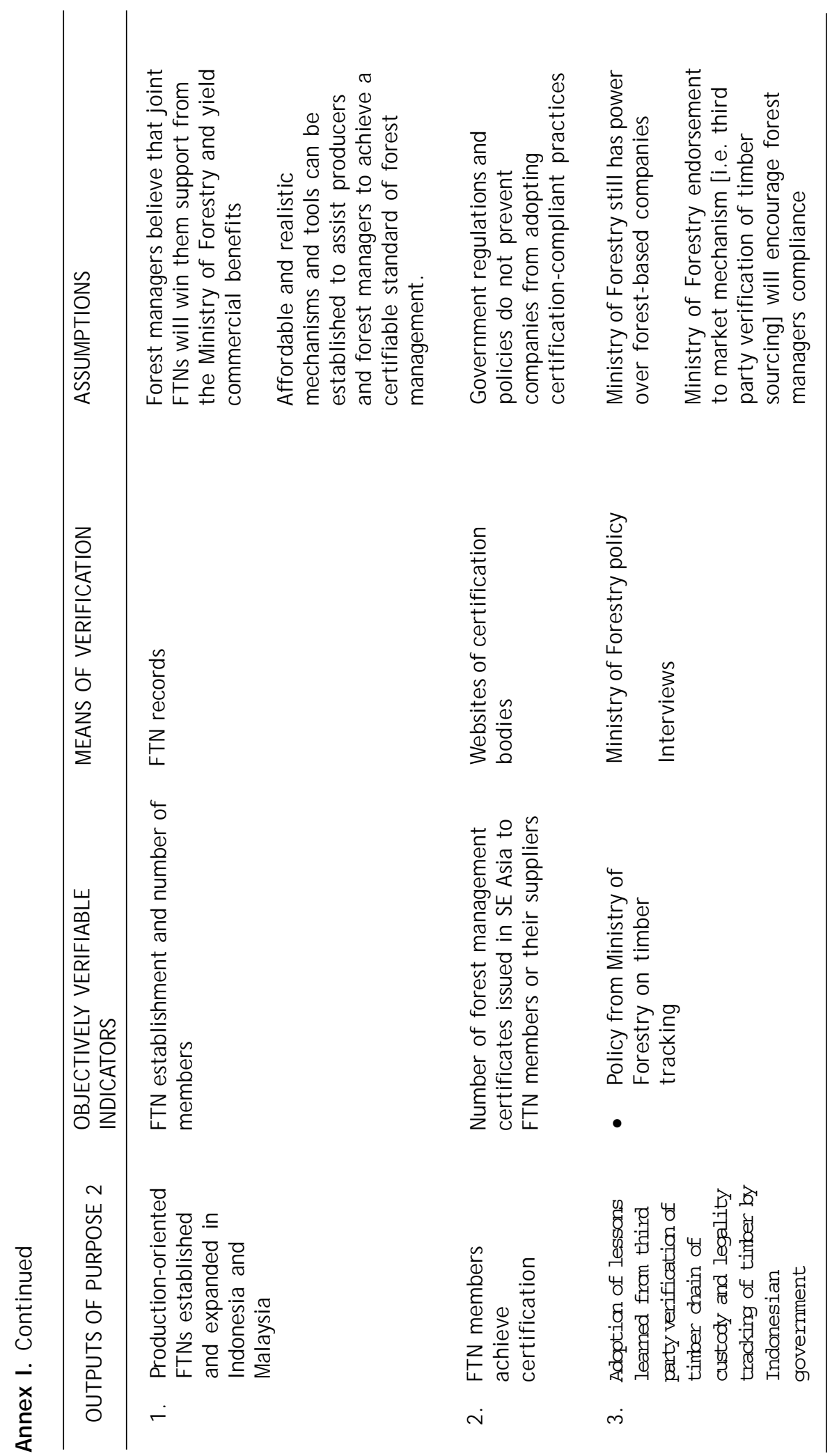




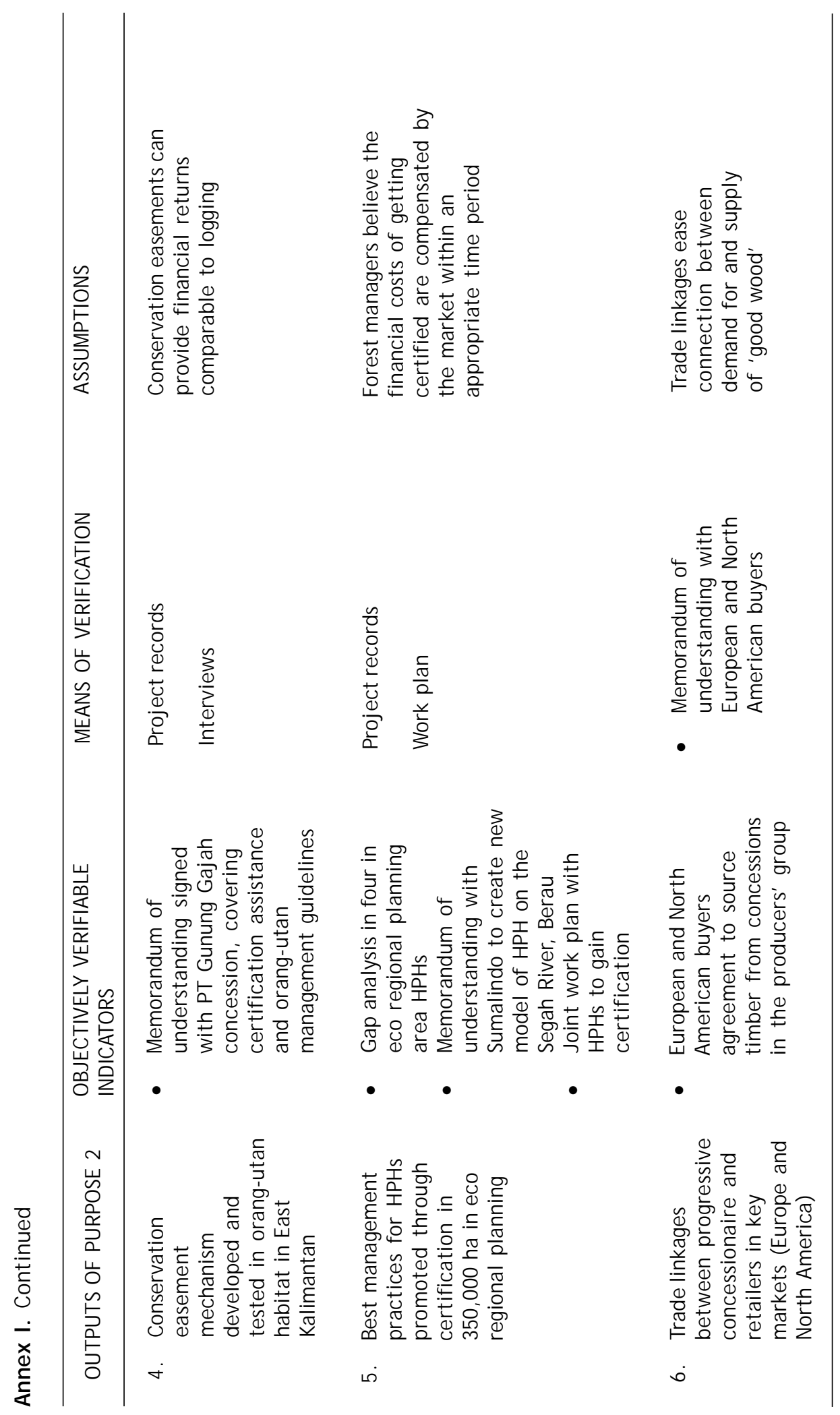




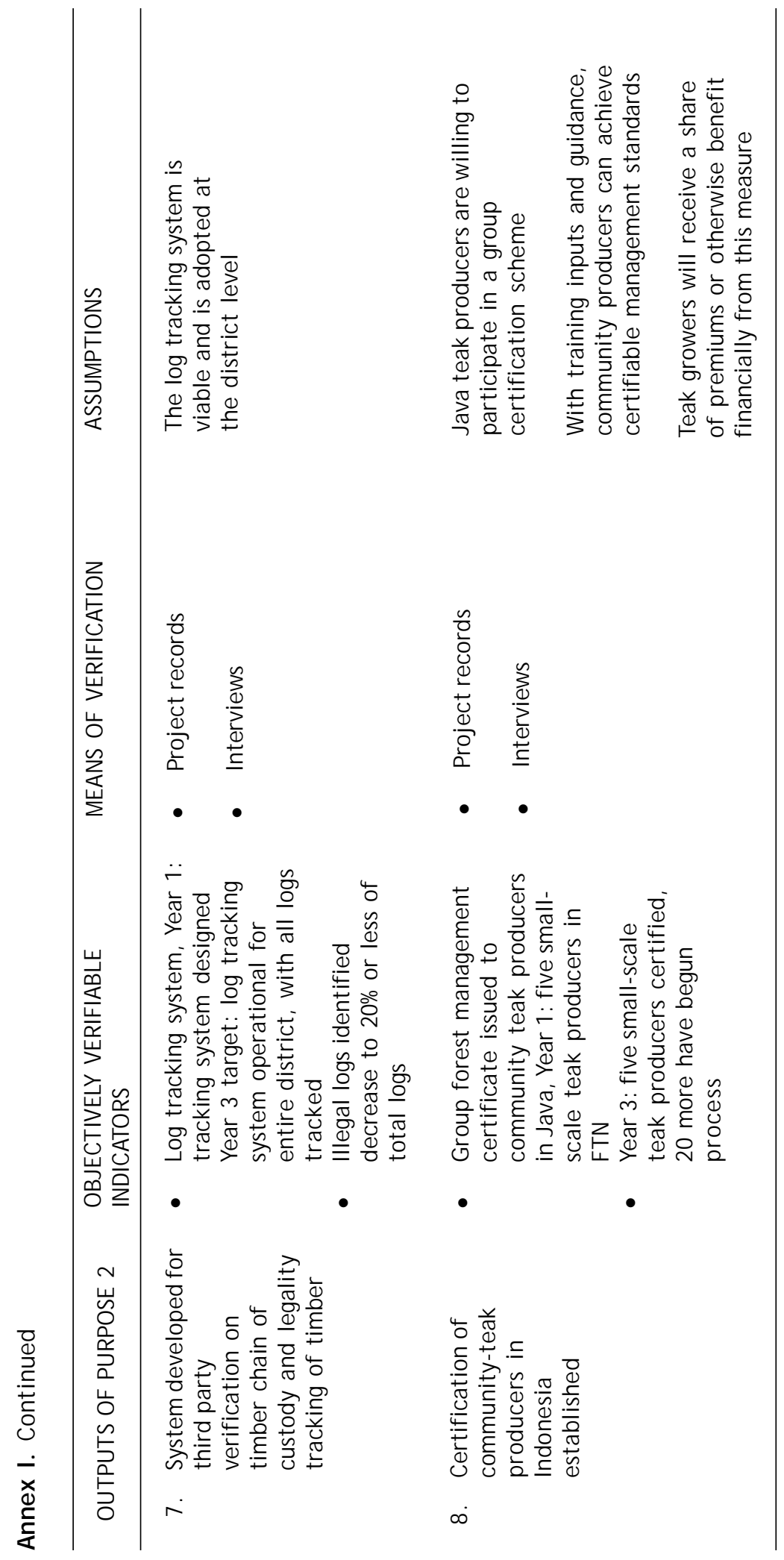




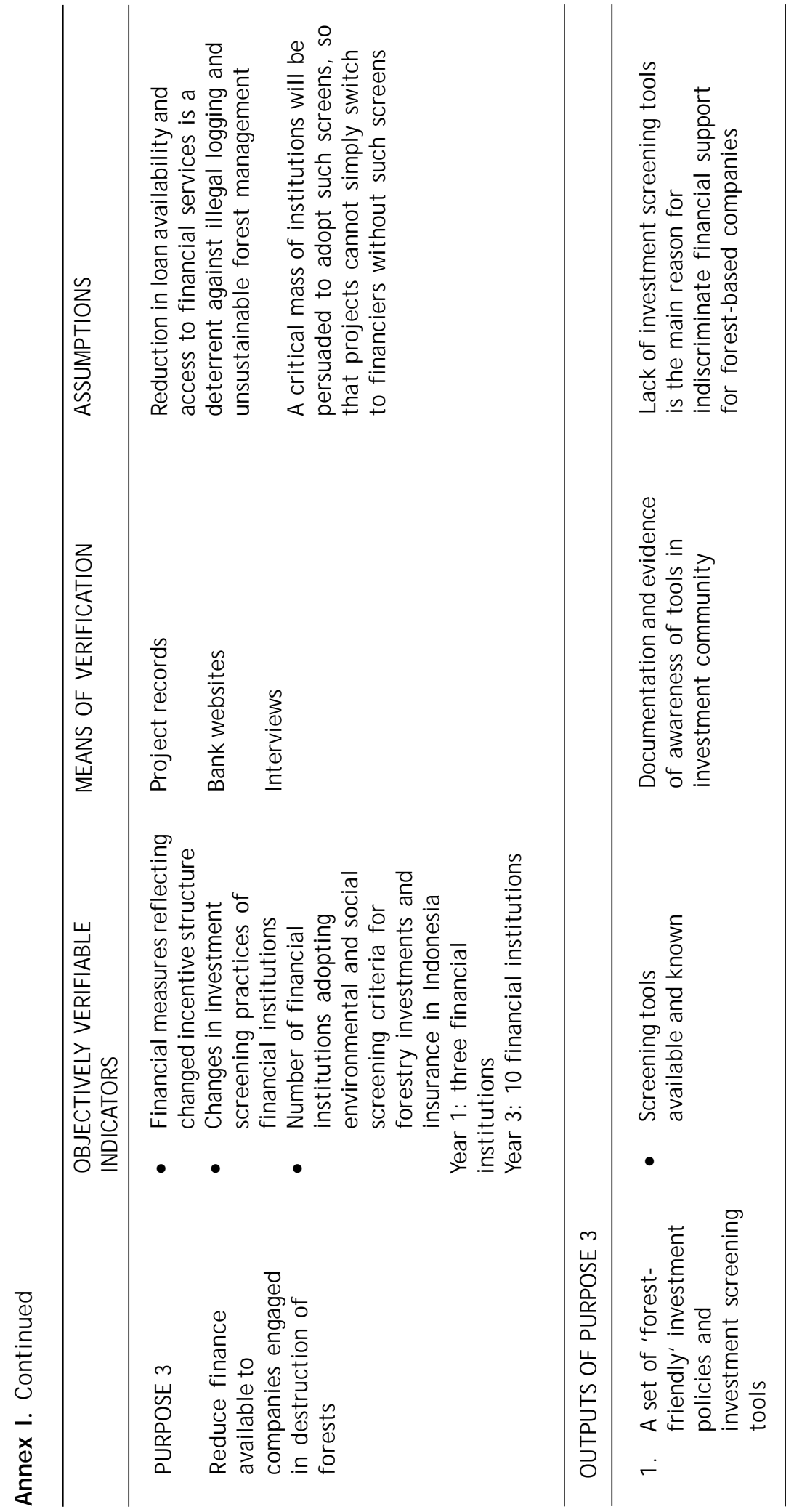




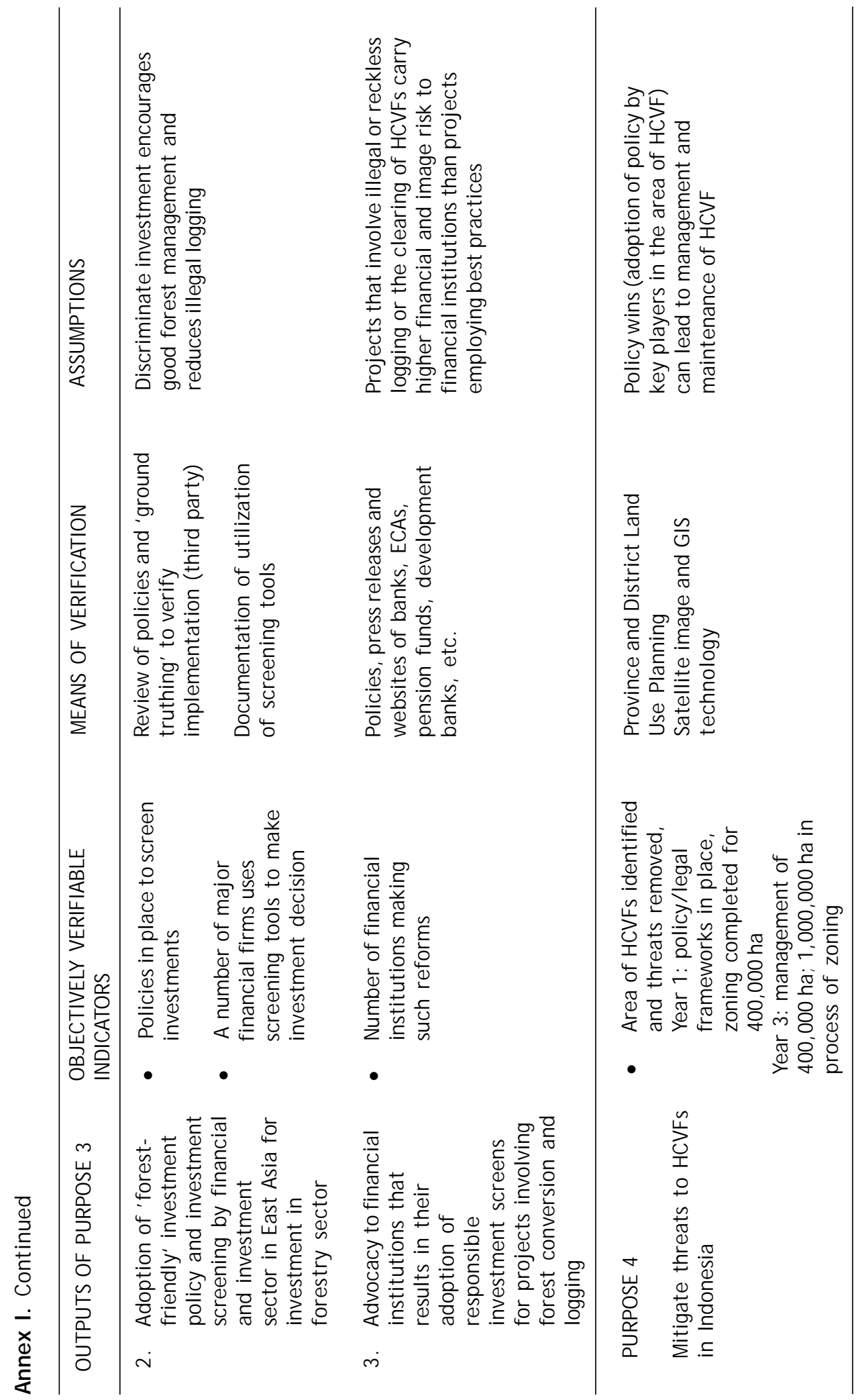




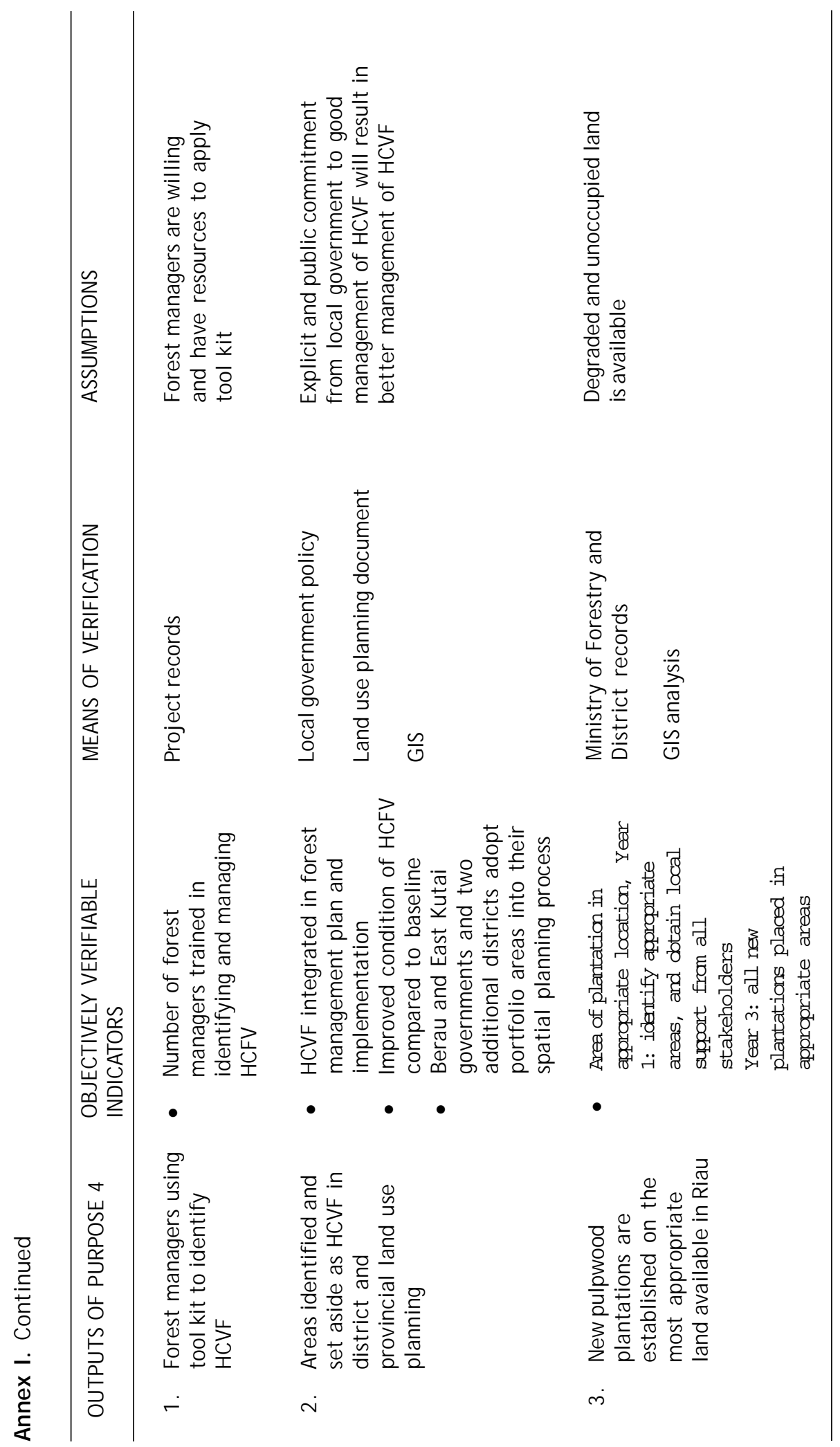




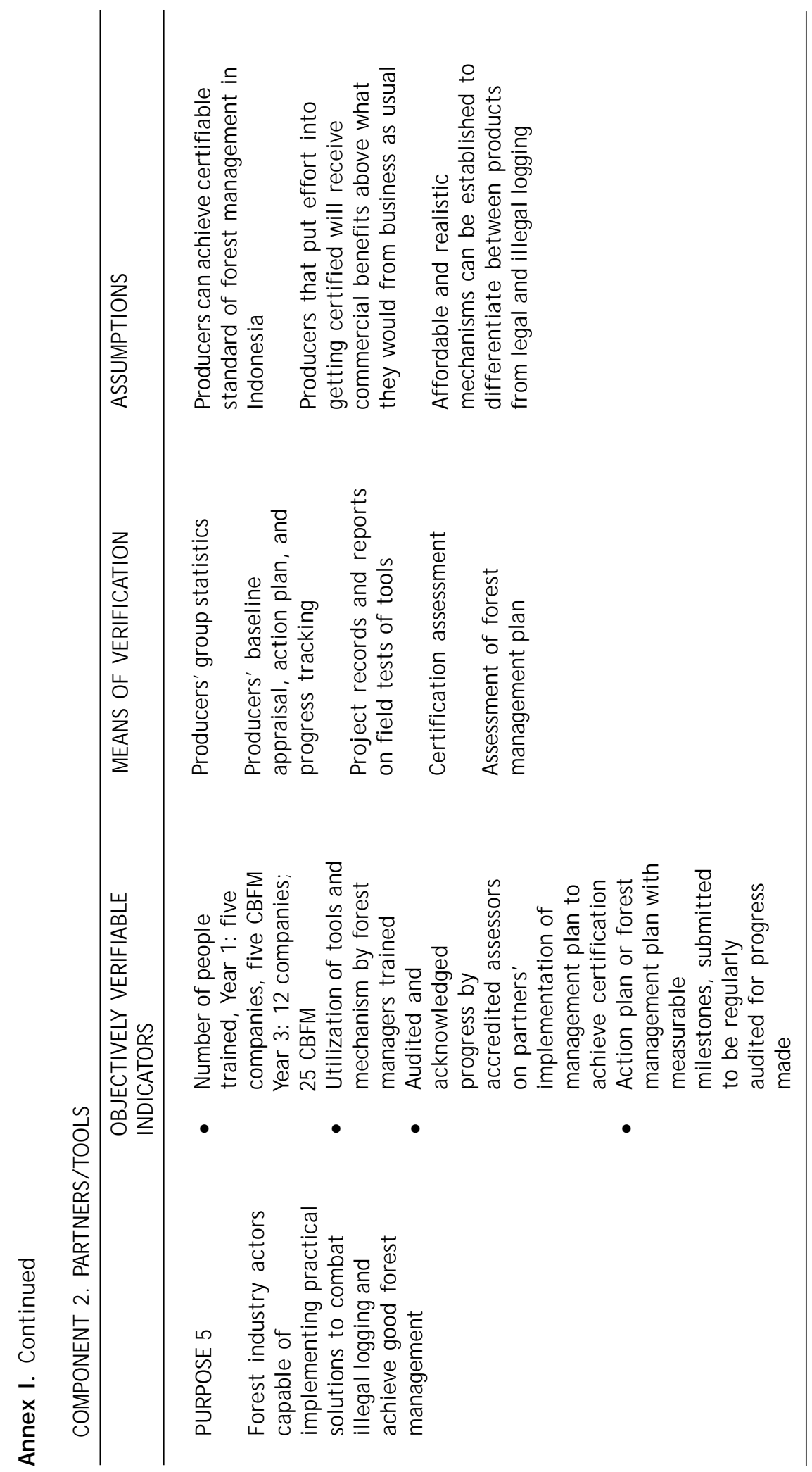




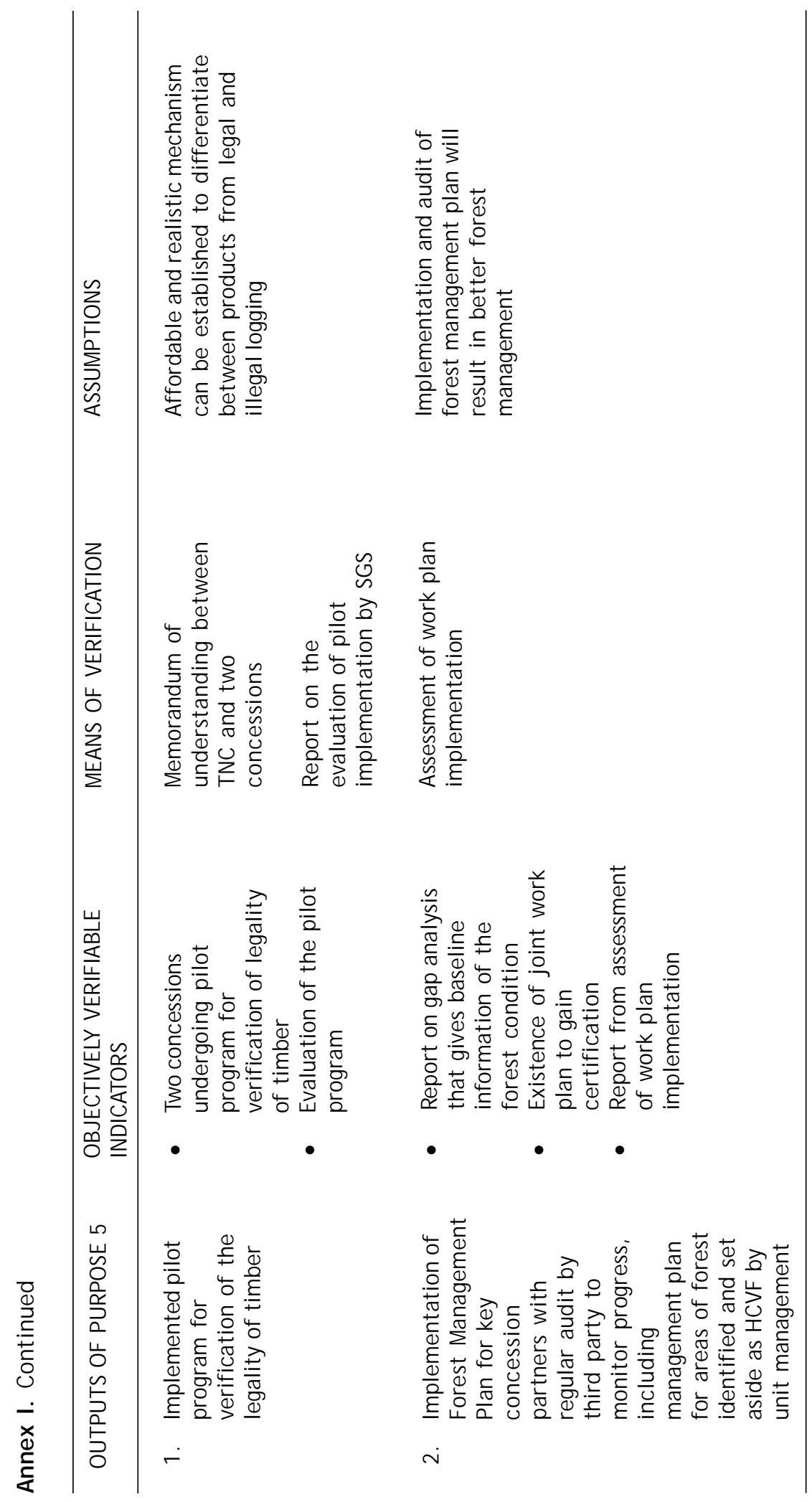




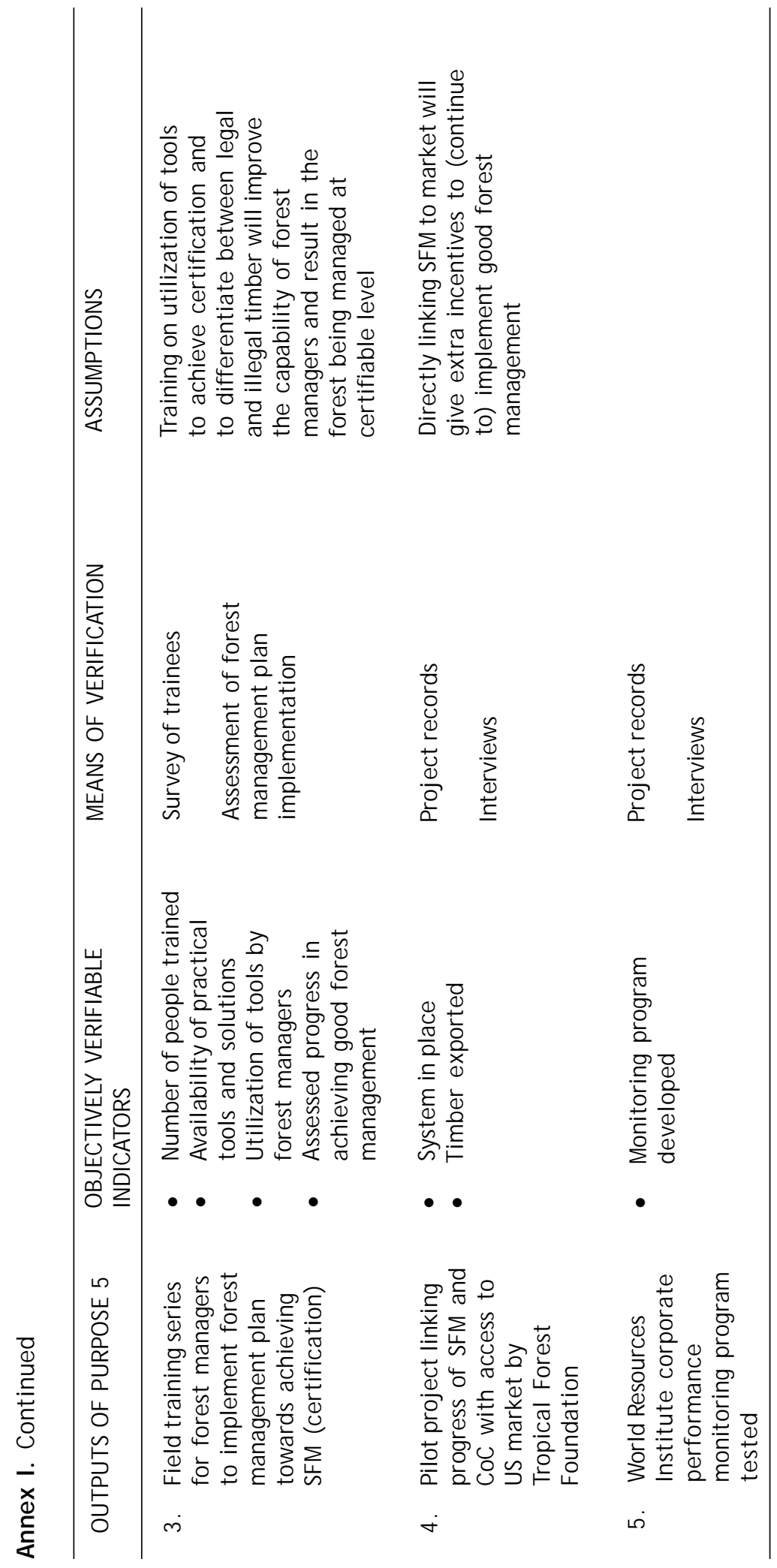




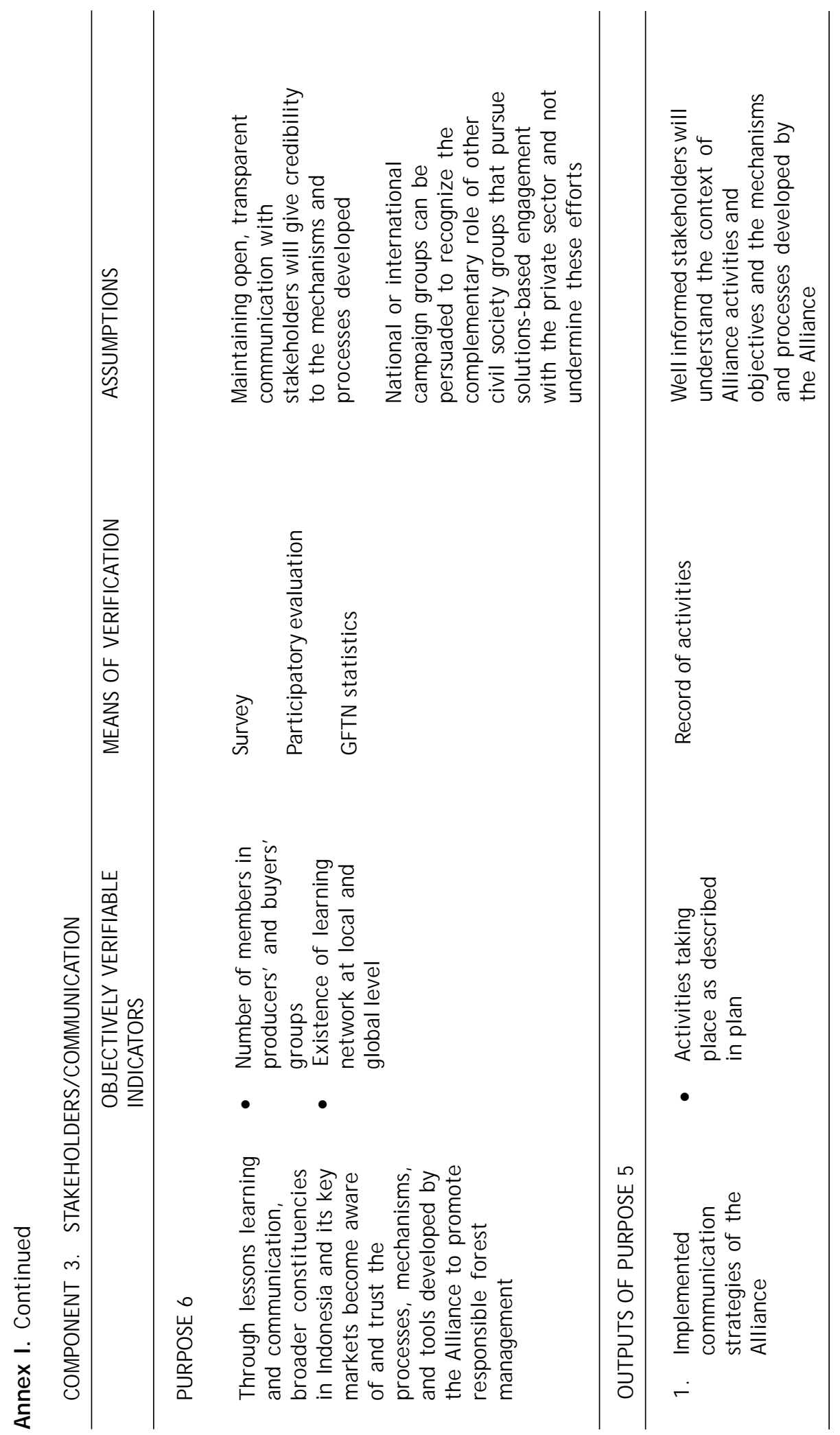




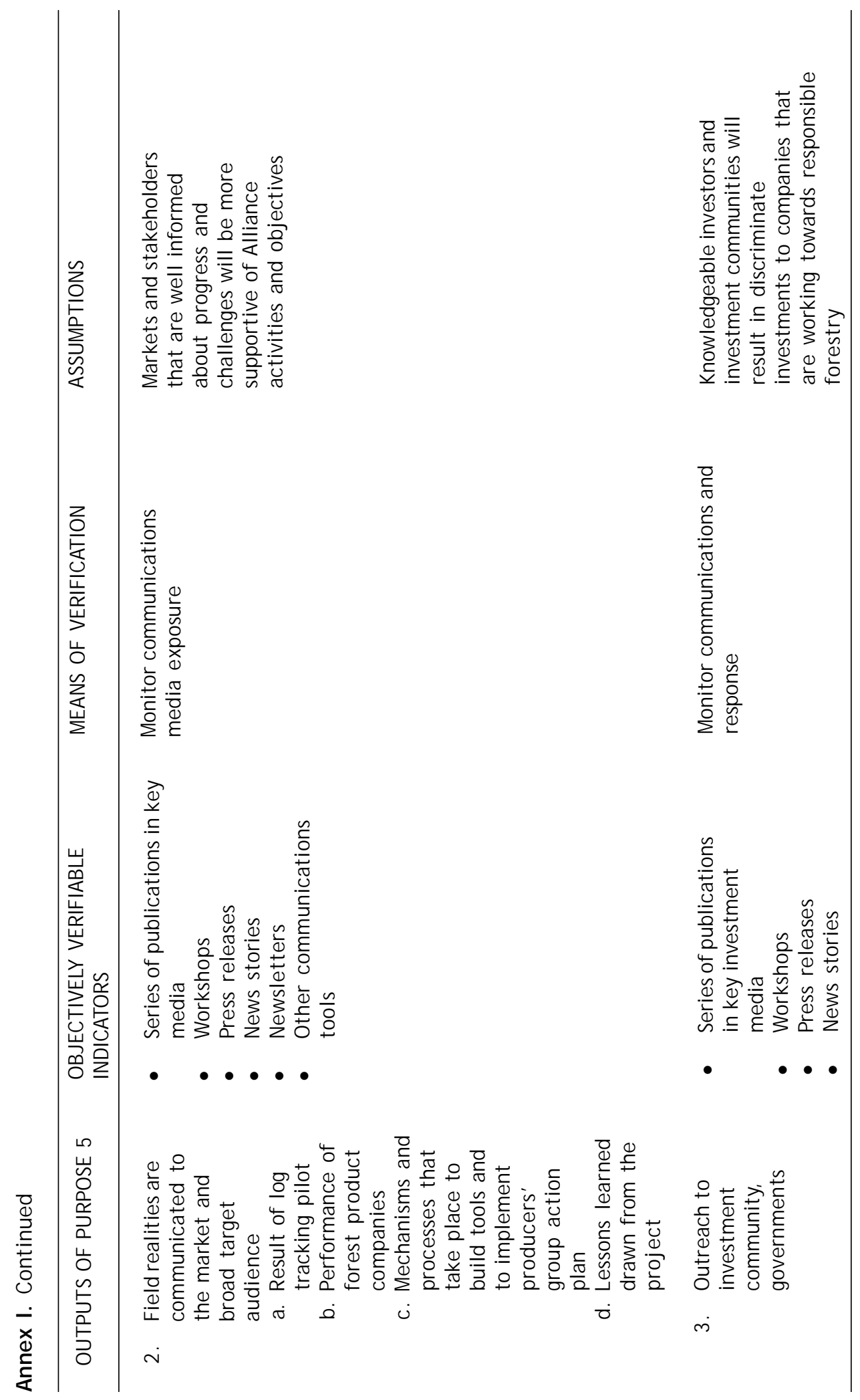




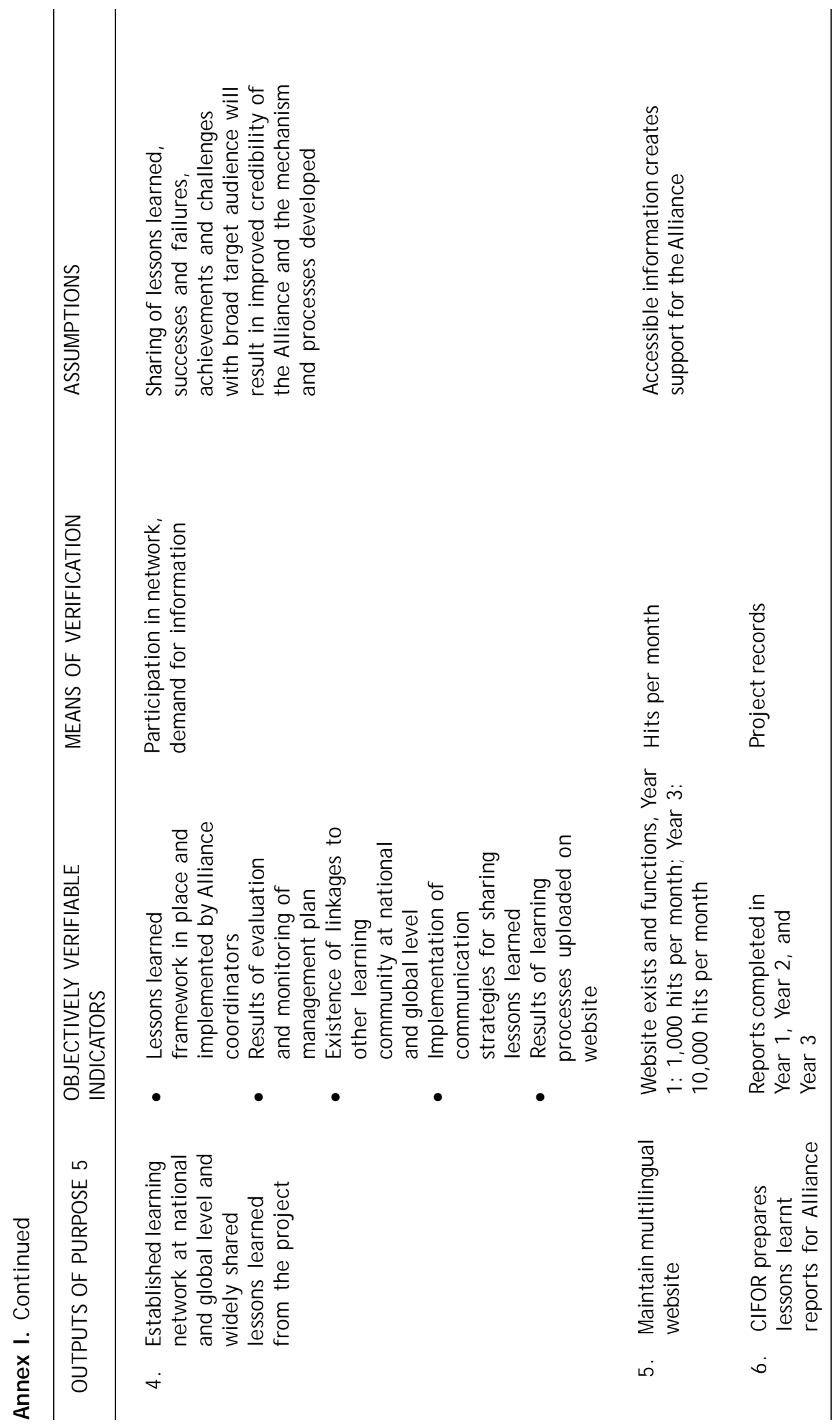




\section{Annex II. CIFOR's Terms of Reference for Preparation of the Annual Report}

1. Compilation of information from the field, TNC, WWF, certifiers, partners and others, and preparation of an annual "Lessons Learned Report" based on the results and experience from each year of the Alliance's actions, including the following:

a. Annual report summarizing lessons learned from the work of the Alliance that are relevant to fulfillment of the Alliance's objectives and to similar work elsewhere. The report will be based upon a compilation of data and information received from TNC, WWF, and other Alliance partners such as Tropical Forest Trust, certifiers, and the Global Forest and Trade Network. While CIFOR is not primarily responsible for the quality and completeness of the information gathered, CIFOR is expected to actively engage with TNC, WWF, and partners to help ensure that the information is made available.

The structure of the lessons learned report should be inspired by the lessons learned framework (see above). An outline for the structure of the report must be presented to TNC and WWF for review and input as an interim output prior to completion of the full report.

b. CIFOR staff will make annual field visits of about six weeks in total to East Kalimantan, Riau and J ava to gather information from local stakeholders, TNC and WWF project staff, and partners engaged with TNC's work who contribute to the objectives of the Alliance in that province.

c. The scope of the lessons learning should be Alliance-wide, including information provided about work in China and J apan and on markets generally.

2. An annual report and PowerPoint presentation on lessons learned from the Alliance that includes the following:

- Brief description of Alliance activities.

- Impacts of the Alliance on enabling conditions.

- Measurement of progress and lessons learned against the various indicators in the log frame.

- $\quad$ Progress and lessons learned in achieving interim results, purpose and goals.

- $\quad$ Narrative content describing why there have been particular successes or difficulties with respect to achieving the Alliance objectives.

- Summary and findings relevant to management and broader sharing of lessons learned. 


\section{Annex III. People and Organisations Contacted}

\begin{tabular}{|c|c|c|}
\hline LOCATION & ORGANISATION & NAME \\
\hline \multirow[t]{16}{*}{ Riau } & WWF-Indonesia, Riau Project & $\begin{array}{l}\text { Bambang Hartono } \\
\text { Zulfira warta } \\
\text { Purwo Susanto } \\
\text { Dudi Ruhendi } \\
\text { Zenwen Pador } \\
\text { Miko } \\
\text { Arif }\end{array}$ \\
\hline & Bappeda, provincial forestry official & Murad \\
\hline & District official & Tengku \\
\hline & Walhi Riau & Rully \\
\hline & Hakiki & Fatra \\
\hline & Komite Advokasi Riau & Zulfahmi \\
\hline & Yayasan Alam Sutera & Mangara Silalahi \\
\hline & Aliansi Tata Ruang & Teguh \\
\hline & Kaliptra & Abah \\
\hline & Riau Mandiri & Kuncoro \\
\hline & Jikalahari & Unyeng \\
\hline & Riau University & Komarudin \\
\hline & Lancang Kuning University & Titik \\
\hline & PT Indah Kiat Pulp and Paper & Alias Abdul J alil \\
\hline & PT Diamond Raya Timber & $\begin{array}{l}\text { Surya Agung } \\
\text { Arus Mujizat }\end{array}$ \\
\hline & PT Riau Andalan Pulp \& Paper & Lorenzo \\
\hline \multirow{16}{*}{$\begin{array}{l}\text { Yogyakarta, } \\
\text { Klaten, Wonogiri }\end{array}$} & & \\
\hline & Arupa & Faisal \\
\hline & & Purnomo Aji \\
\hline & & Rama \\
\hline & & Ronald \\
\hline & & Suryanto \\
\hline & District forestry official & Topik \\
\hline & Gajah Mada University & San Afri Awang \\
\hline & INSIST Yogya & R. Yando Zakaria \\
\hline & Damar (NGO) & Yayan \\
\hline & Wood trader & Samin \\
\hline & Kotrika (small holder & \\
\hline & furniture association) & Tari, Nyono \\
\hline & Association for Study and & \\
\hline & Social Economic Development & To \\
\hline & Teak farmer & Misman \\
\hline \multirow{5}{*}{$\begin{array}{l}\text { East Kalimantan } \\
\text { (Samarinda/ } \\
\text { Berau) }\end{array}$} & & \\
\hline & TNC Samarinda & Scott Stainley \\
\hline & & Yosep Ruslim \\
\hline & & Edi Sudiono \\
\hline & & Sophia Lena \\
\hline
\end{tabular}


Annex III. Continued

\begin{tabular}{|c|c|c|}
\hline LOCATION & ORGANISATION & NAME \\
\hline \multicolumn{3}{|c|}{$\begin{array}{l}\text { East Kalimantan } \\
\text { (Samarinda/ }\end{array}$} \\
\hline \multirow[t]{28}{*}{ Berau) } & APHI/ MPI & Djafar Hammna \\
\hline & Mulawarman University & $\begin{array}{l}\text { Prof. Wawan Kustiawan } \\
\text { Dr. Sumaryono }\end{array}$ \\
\hline & East Kalimantan Producer Group & Prof. Suyitno Sudirman \\
\hline & Tropical Forest Trust & Ben J arvis \\
\hline & PT Gunung Gajah & Roso \\
\hline & PT Sumalindo & Bayu, Hartono \\
\hline & PT Daisy Timber & Prof. Abubakar L \\
\hline & PT Intracawood & Taufan \\
\hline & Provincial Forestry Office & Aminullah, Miftah Soma \\
\hline & BSPHH & Bambang Riyanto \\
\hline & Bebsic (NGO) & Uut \\
\hline & Walhi Kaltim (NGO) & \\
\hline & SHK Kaltim (NGO) & Yoga S. \\
\hline & Bioma (NGO) & Wijaya \\
\hline & TNC Berau & $\begin{array}{l}\text { Atun, Agus, Wiwied, } \\
\text { Odang, J unaedi }\end{array}$ \\
\hline & Laperma (NGO) & Jon \\
\hline & Berau Lestari (NGO) & Ryan \\
\hline & & Hamzah \\
\hline & Kalbu (NGO) & Darwis \\
\hline & Bappeda (District Planning Office) & Rajuddin \\
\hline & Dinas Kehutanan (District & \\
\hline & Forestry Office) & Achmad Delmi \\
\hline & $\begin{array}{l}\text { UPTD (District Forestry Office, } \\
\text { affiliate to provincial office) }\end{array}$ & Hazairin \\
\hline & Berau Forest Management Project & R. Giambelli \\
\hline & & Dadang \\
\hline & PT Hutan Sanggam Labanan & \\
\hline & (Inhutani I) & Dodi Herika \\
\hline & PT Sumalindo Lestari J aya IV & Bambang \\
\hline \multirow[t]{11}{*}{ J akarta } & Ministry of Forestry (Pustanling) & Tri Djoko \\
\hline & Association of Indonesian & \\
\hline & Forest Concessionaires-J akarta & Rukmantara \\
\hline & World Wide Fund for Nature & Anwar \\
\hline & & Nurcahyo Adi \\
\hline & & Rod Taylor \\
\hline & The Nature Conservancy & Nigel Sizer \\
\hline & & Moray McLeish \\
\hline & & Yudi Iskandarsyah \\
\hline & & Upik Djalins \\
\hline & & Kath Shurcliff \\
\hline \multirow[t]{4}{*}{ International } & Societe Generale de Surveillance, & \\
\hline & Malaysia & Kevin Grace \\
\hline & & Salahudin Yacob \\
\hline & Forest Stewardship Council, Bonn & Alistair Monument \\
\hline
\end{tabular}


Illegal logging is a cause for widespread concern. It has negative environmental impacts, results in the loss of forest products used by rural communities, creates conflicts, and causes significant losses of tax revenues that could be used for development activities. The Nature Conservancy and World Wide Fund for Nature developed the Alliance to Promote Certification and Combat Illegal Logging in Indonesia to respond to the concern about illegal logging. The Alliance is a three-year initiative that aims to:

1. Strengthen market signals to expand certification and combat illegal logging.

2. Increase supply of certified Indonesian wood products.

3. Demonstrate practical solutions to achieve certification and differentiate legal and illegal supplies

4. Reduce financing and investment in companies engaged in destructive or illegal logging in Indonesia.

5. Share lessons learned from the project.

The Alliance seeks to learn lessons from its ongoing work to inform and adapt its activities, as well as to inform other initiatives seeking to address similar problems. This report is part of this lessons learning process.

This report assesses the situation in Indonesia, including a quantitative estimation of illegally produced logs, discusses the causes of illegal logging, and describes the national and international policy and trade context. Then, it considers the work undertaken by the Alliance to address illegal logging in Indonesia; it summarizes the strategy of the Alliance, describes its rationale, and assesses the assumptions underlying the rationale and the objectives. Finally, it summarizes the progress made by the Alliance towards achieving its goal, highlights the lessons that can be learnt from the work in progress, and provides recommendations for the Alliance.
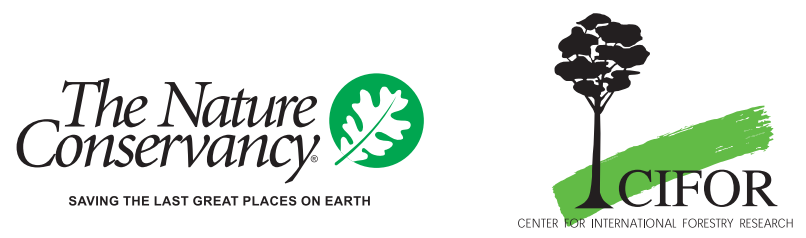